\title{
Influência do Oxigênio no Crescimento de Arquéias Metanogênicas e Bactérias Redutoras de Sulfato em Reatores Anaeróbios em Batelada
}

Dissertação apresentada à Escola de Engenharia de São Carlos da Universidade de São Paulo, como parte dos requisitos para obtenção do Título de Mestre em Hidráulica e Saneamento.

Orientador: Profa. Dra. Maria Bernadete A. Varesche 
AUTORIZO A REPRODUÇÃO E DIVULGAÇÃO TOTAL OU PARCIAL DESTE TRABALHO, POR QUALQUER MEIO CONVENCIONAL OU ELETRONICO, PARA FINS DE ESTUDO E PESQUISA, DESDE QUE CITADA A FONTE.

Ficha catalográfica preparada pela Seção de Tratamento da Informaçāo do Serviço de Biblioteca - EESC/USP

\begin{tabular}{|c|c|}
\hline \multirow[t]{3}{*}{ S249i } & $\begin{array}{l}\text { Sarti, Érika Lamaro } \\
\text { Influência do oxigênio no crescimento de arquéias } \\
\text { metanogênicas e bactérias redutoras de sulfato em } \\
\text { reatores anaeróbios em batelada / Érika Lamaro Sarti ; } \\
\text { orientador Maria Bernadete A. Varesche. -- São Carlos, } \\
2007 \text {. }\end{array}$ \\
\hline & $\begin{array}{l}\text { Dissertação (Mestrado) - Programa de Pós-Graduação e } \\
\text { Area de Concentração em Hidráulica e Saneamento -- Escola } \\
\text { de Engenharia de Săo Carlos da Universidade de São Paulo. }\end{array}$ \\
\hline & $\begin{array}{l}\text { 1. Bactérias redutoras de sulfato. 2. Arquéias } \\
\text { metanogênicas. 3. Oxigênio. 4. Reatores em batelada. } \\
\text { 5. FISH. I. Título. }\end{array}$ \\
\hline
\end{tabular}




\section{、 FOLHA DE JULGAMENTO}

Candidata: Licenciada ERIKA LAMARO SARTI

Dissertação defendida e julgada em 10/05/2007 perante a Comissão Julgadora:

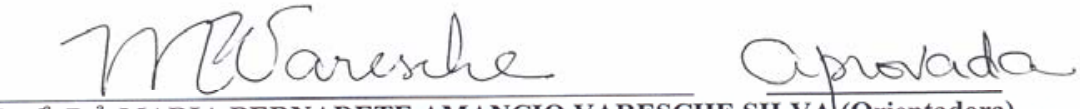
Prof $f^{\mathrm{a}}$. Dr ${ }^{\mathrm{a}}$. MARIA BERNADETE AMANCIO VARESCHE SILVAl(Orientadora) (Escola de Engenharia de São Carlos/USP)
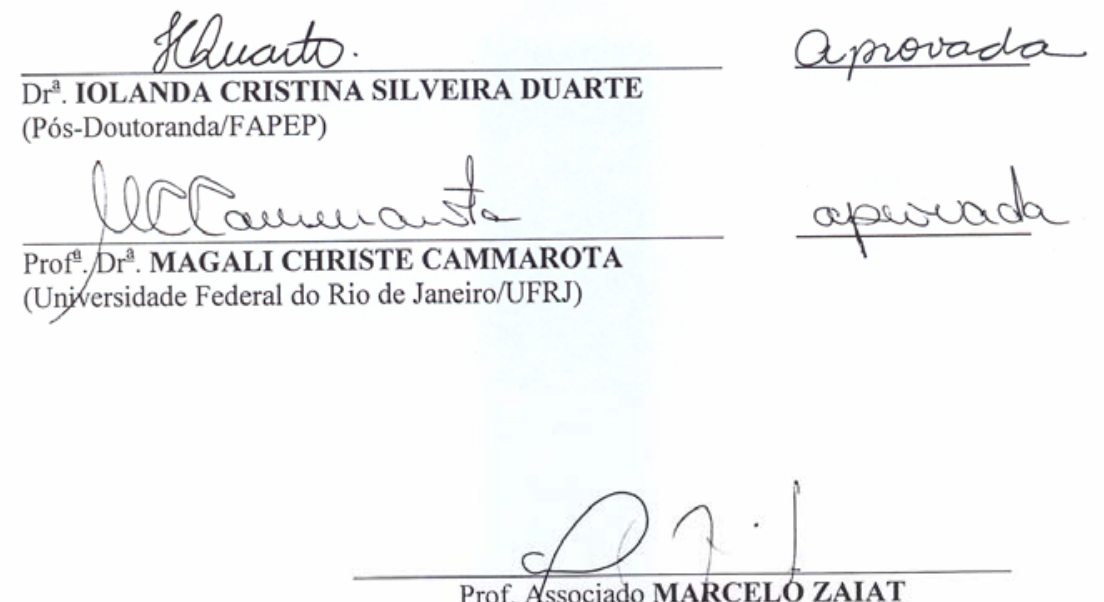

Prof. Associado MARCELO ZAIAT

Coordenalor do Programa de Pós-Graduação em Engenharia (Hidráulica e Saneamento)

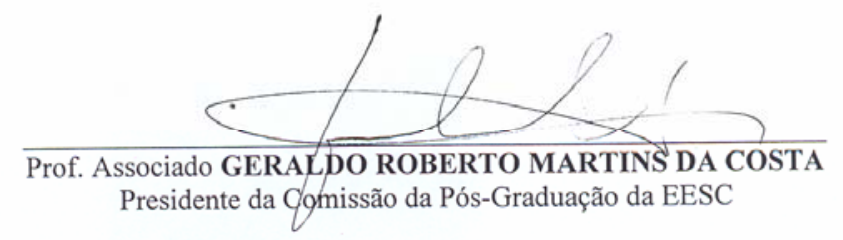


Aos meus pais, Antonio

Carlos e Maria José, e ao

Thel. 


\section{AGRADECIMENTOS}

Á Profa. Dra. Maria Bernadete, pela amizade, orientação e paciência durante a realização deste trabalho.

Ao Prof. Dr. Marcelo Zaiat pela disponibilidade de esclarecer dúvidas e pelas sugestões e críticas no exame de qualificação.

Ao CNPq pela concessão da bolsa de estudos durante o período de vigência do Mestrado.

Às secretárias do Departamento de Hidráulica e Saneamento Sá e Pavi pela ajuda com assuntos burocráticos, e também à Rose.

Á profa. Beth Moraes, Janja e Eloísa, pela constante ajuda nas análises cromatográficas e microscopia.

À FAPESP (Fundação de Apoio à Pesquisa do Estado de São Paulo), pelo auxílio financeiro através do Projeto Temático "Desenvolvimento de Sistemas Combinados de Tratamento de Águas Residuárias Visando a Remoção de Poluentes e a Recuperação de energia e de Produtos dos Ciclos de Carbono, Nitrogênio e Enxofre”.

A todo pessoal do LPB: Carol, Tiago, Sandra, Daniele, Júlia, Luís Ricardo, Gunther, Kátia, Iolanda, Lorena, Noemi, Alexandre, Renata, Leonardo, Arnaldo, Márcia, Margarita e todo pessoal da iniciação científica, pela amizade, ajuda e bons momentos vividos no laboratório.

À Júlia pela ajuda com o FISH.

Às amigas de casa, Thaís, Sulita e Silvia pela companhia, conversas e bons momentos.

Aos amigos do mestrado pela amizade e momentos de descontração.

À minha família, pelo constante apoio. 


\section{RESUMO}

SARTI, E. L. Influência do oxigênio no crescimento de arquéias metanogênicas e bactérias redutoras de sulfato em reatores anaeróbios em batelada. 2007. 114p. Dissertação (Mestrado) - Escola de Engenharia de São Carlos, Universidade de São Paulo, São Carlos, 2007.

Este trabalho teve como objetivo avaliar o comportamento de arquéias metanogênicas e bactérias redutoras de sulfato na presença de oxigênio, em reatores anaeróbios em batelada, sob condições sulfetogênicas e mesofílicas. Os reatores foram inoculados com lodo anaeróbio proveniente de reator UASB utilizado no tratamento de água residuária de avicultura. Triplicatas de reatores foram alimentadas com meio basal ZINDER, acrescido de acetato de sódio, etanol ou lactato de sódio e sulfato de sódio, de modo a se obter relações DQO/sulfato iniciais de 1,1-1,5. O headspace dos reatores foi preenchido com $\mathrm{N}_{2}$ (100\%) acrescido de oxigênio puro comercial (33,5 mg/L de oxigênio dissolvido). Os reatores anaeróbios controle foram alimentados com os mesmos substratos orgânicos, entretanto, seu headspace foi preenchido com $\mathrm{N}_{2} / \mathrm{CO}_{2}$ (70/30\%). Nos reatores com acetato de sódio, etanol e lactato de sódio as velocidades de produção de metano foram de $0,30 \mathrm{mmol} / \mathrm{L} . \mathrm{h}, 0,41 \mathrm{mmol} / \mathrm{L} . \mathrm{h}$ e $0,16 \mathrm{mmol} / \mathrm{L} . \mathrm{h}$, respectivamente, para os reatores controle. Em relação aos reatores com oxigênio os valores foram de 0,27 mmol/L.h, 0,40 mmol/L.h e 0,08 mmol/L.h, respectivamente. Na presença de acetato, etanol e lactato a redução de sulfato foi de $57 \%$ e $97 \%$; $59,6 \%$ e 76,6\%; 77,5\% e 41,9\%, respectivamente, nos reatores controle e com oxigênio. Nos reatores com acetato e etanol houve predomínio de organismos do Domínio Archaea nos reatores controle (59,2\% e 58,8\%) e com oxigênio (60,7\% e 54,5\%), respectivamente. No reator controle contendo lactato, também ocorreu o predomínio de arquéias metanogênicas (56,2\%), enquanto na presença de oxigênio houve predomínio de organismos do Domínio Bacteria (63,9\%). As proporções de BRS nos reatores controle e com oxigênio contendo acetato, etanol e lactato foram de 22\% e 17,3\%; $28 \%$ e 16,9\%; 19,5\% e 21,9\%, respectivamente. $\mathrm{O}$ oxigênio não inibiu a metanogênese e nem a redução de sulfato nos reatores contendo acetato e etanol.

Palavras-chave: bactérias redutoras de sulfato, arquéias metanogênicas, oxigênio, reatores em batelada, FISH. 


\begin{abstract}
SARTI, E. L. Oxygen influence on methanogenic archaea and sulfate reducing bacteria's growth in anaerobic batch reactors. 2007. 114p. Msc Dissertation. - Escola de Engenharia de São Carlos, Universidade de São Paulo, São Carlos, 2007.

This work aimed to evaluate the behavior of methanogenic archaea and sulfate reducing bacteria in the presence of oxygen, using anaerobic batch reactors under sulfidogenic and mesophilic conditions. The reactors were inoculated with anaerobic sludge from UASB reactor treating poultry wastes. Third copies of the reactors were fed with ZINDER medium, increased with sodium acetate, ethanol or sodium lactate and sodium sulfate, in order to get COD/sulfate ratio of 1,1-1,5. The headspace of the reactors was filled with $\mathrm{N}_{2}$ (100\%) and increased with oxygen (OD concentration of $3-3.5 \mathrm{mg} / \mathrm{L})$. The anaerobic control reactors were fed with the same organics substrates, however, the headspace was filled with $\mathrm{N}_{2} / \mathrm{CO}_{2}$ (70/30\%). The rates of methane production were $0.30 \mathrm{mmol} / \mathrm{L} . \mathrm{h}, 0.41 \mathrm{mmol} / \mathrm{L} . \mathrm{h}$ and $0.16 \mathrm{mmol} / \mathrm{L} . \mathrm{h}$, in acetate, ethanol and lactate controls reactors, respectively. In oxygen reactors, the rates of methane production were 0.27 $\mathrm{mmol} / \mathrm{L} . \mathrm{h}, 0.40 \mathrm{mmol} / \mathrm{L} . \mathrm{h}$ and $0.08 \mathrm{mmol} / \mathrm{L} . \mathrm{h}$ in acetate, ethanol and lactate reactors, respectively. The rates of sulfate reduction in acetate, ethanol and lactate reactors were $57 \%$ and $97 \%$; $59.6 \%$ and 76.6\%; $77.5 \%$ and $41.9 \%$, respectively, in control reactors and oxygen reactors. In acetate and ethanol reactors, were verified predominance of Archaea Domain in control reactors (59.2\% and 58.8\%) end oxygen reactors (60.7\% and 54.5\%), respectively. In lactate control reactor also was verified predominance of Archaea Domain (56.2\%), whereas in lactate oxygen reactors there was predominance of cells belonging to Bacteria Domain (63.9\%). BRS ratio in acetate, ethanol and lactate control reactors and oxygen reactors corresponded to $22 \%$ and $17.3 \%$; $28 \%$ and $16.9 \% ; 19.5 \%$ and $21.9 \%$, respectively. The addition of oxygen didn't inhibit the methanogenesis and sulfate reduction in acetate reactors and in ethanol reactors.
\end{abstract}

Keywords: sulfate reducing bacteria, methanogenic archaeas, oxygen, batch reactors and FISH. 


\section{LISTA DE FIGURAS}

Figura 4.1. Fluxograma das atividades experimentais.................................................... 28

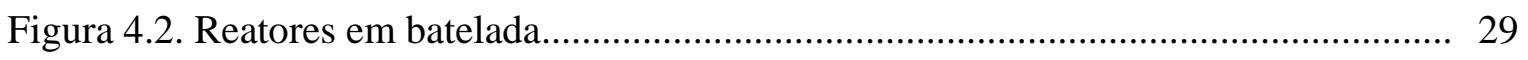

Figura 4.3. Lâmina de vidro revestida de teflon utilizada no FISH................................... 39

Figura 5.1. Variação temporal da concentração de ácido acético nos reatores em batelada 43

Figura 5.2. Variação temporal da concentração de metano nos reatores contendo acetato,

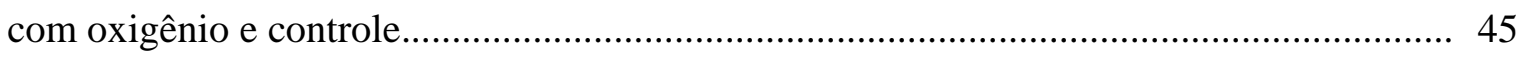

Figura 5.3. Variação temporal da concentração de sulfato e sulfeto nos reatores contendo acetato e oxigênio

Figura 5.4. Variação temporal da concentração de sulfato e sulfeto nos reatores controle contendo acetato.

Figura 5.5. Morfologias observadas no inóculo sob microscopia óptica de contrate de fase e fluorescência: (a) morfologia semelhante a Methanosarcina sp., (b) fluorescência de Methanosarcina sp., (c) filamentos e (d) bacilos com extremidades arredondadas........ 50 Figura 5.6. Composição da comunidade microbiana do inóculo. Abundância relativa de células pertencentes aos Domínios Bacteria (EUB338) e Archaea (ARC915) e BRS da subdivisão delta de Proteobacteria (SRB385) e soma dos dois Domínios (EUB338 + ARC915). As barras indicam o erro padrão.

Figura 5.7. Morfologias hibridadas com a sonda EUB338: (a) células coradas com DAPI, (b) bacilo (seta branca) e cocos em forma de sarcina.

Figura 5.8. Morfologias observadas em microscopia óptica de contrate de fase nos reatores controle contendo acetato (a-c) e com adição de oxigênio (d-f): (a) morfologias semelhantes a Methanosarcina sp., (b) cocos, (c) morfologias semelhantes a Methanosaeta sp., (d) filamentos segmentados, (e) cocobacilos, (f) bacilo curvo.

Figura 5.9. Comunidade microbiana nos reatores controle e com oxigênio contendo acetato. Abundância relativa de células pertencentes aos Domínios Bacteria (EUB338) e Archaea (ARC915) e grupo das BRS da subdivisão delta de Proteobacteria (SRB385) e soma dos dois Domínios (EUB338 + ARC915). As barras indicam o erro padrão.

Figura 5.10. Variação temporal da concentração de etanol nos reatores em batelada 
Figura 5.11. Variação temporal da concentração máxima de metano nos reatores contendo etanol com oxigênio e controle.

Figura 5.12. Variação temporal da concentração de sulfato e sulfeto no biogás dos reatores contendo etanol e oxigênio.

Figura 5.13. Variação temporal da concentração de sulfato e sulfeto no biogás dos reatores controle contendo etanol

Figura 5.14. Morfologias observadas sob microscopia óptica de contraste de fase nos reatores alimentados com etanol controle (a-b) e com oxigênio (c-d): (a) cocos e filamentos segmentados, (b) bacilo com extremidade arredondada e bacilo curvo, (c) Methanosaeta sp., (d) bacilos curvos.

Figura 5.15. Comunidade microbiana nos reatores controle e com oxigênio contendo etanol. Abundância relativa de células pertencentes aos Domínios Bacteria (EUB338), Archaea (ARC915), BRS da subdivisão delta de Proteobacteria (SRB385) e soma dos dois Domínios (EUB338 + ARC915). As barras indicam o erro padrão.

Figura 5.16. Variação temporal do ácido lático nos reatores em batelada....

Figura 5.17. Variação temporal da concentração de metano nos reatores contendo lactato com oxigênio e controle.

5.18. Variação temporal da concentração de sulfato e sulfeto nos reatores contendo lactato e oxigênio...

Figura 5.19. Variação temporal da concentração de sulfato e sulfeto nos reatores controle contendo lactato...

Figura 5.20. Morfologias observadas sob microscopia óptica de contraste de fase nos reatores alimentados com lactato controle (a-b) e com oxigênio (c-d): (a) bacilos curvos semelhantes a Desulfovibrio sp., (b) bacilo curvo (seta preta), cocobacilos (seta vermelha) e filamento semelhante a Methanosaeta sp. (seta amarela), (c) cocos (seta preta) e bacilos com extremidades arredondadas (seta vermelha), (d) cocobacilos em pares (seta preta), bacilos com extremidades arredondadas (seta vermelha) e cocobacilos (seta amarela).

Figura 5.21. Comunidade microbiana nos reatores controle e com oxigênio alimentados com lactato. Abundância relativa de células pertencentes aos Domínios Bacteria (EUB338), Archaea (ARC915), BRS da subdivisão delta de Proteobacteria (SRB385) e 
soma dos dois Domínios (EUB338 + ARC915). As barras indicam o erro padrão...

81

Figura 5.22. Morfologias hibridadas com a sonda EUB338 nos reatores contendo lactato com oxigênio: (a) coloração com DAPI, (b) bacilos... 


\section{LISTA DE TABELAS}

Tabela 4.1. Composição do meio basal Zinder................................................................. 30

Tabela 4.2. Composição da solução traço de metais....................................................... 31

Tabela 4.3. Composição da solução de vitaminas........................................................... 31

Tabela 4.4. Composição dos reatores em batelada........................................................... 33

Tabela 4.5. Sondas de oligonucleotídeos utilizadas na hibridação fluorescente in situ....... 37

Tabela 4.6. Concentrações-estoque de cada sonda......................................................... 38

Tabela 4.7. Protocolos de hibridação................................................................................ 41

Tabela 5.1. Relação DQO/sulfato, DQO inicial, potencial de oxi-redução, eficiência de remoção de DQO e sólidos totais voláteis dos reatores em batelada com acetato............... 43

Tabela 5.2. Velocidade máxima de produção de metano e concentração máxima de metano nos reatores alimentados com acetato de sódio.

Tabela 5.3. Consumo de sulfato, início do tempo de detecção de sulfeto no biogás e concentração máxima de sulfeto nos reatores contendo acetato........................................ 47

Tabela 5.4. Caracterização morfológica do inóculo........................................................... 51

Tabela 5.5. Porcentagens de microrganismos obtidos no inóculo por meio do FISH.......... 52

Tabela 5.6. Morfologias das células predominantes no inóculo detectadas pelo FISH....... 52

Tabela 5.7. Caracterização morfológica dos reatores contendo acetato............................. 54

Tabela 5.8. Porcentagens de microrganismos obtidos com o FISH nos reatores controle e

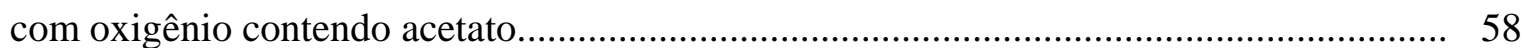

Tabela 5.9 Morfologias das células predominantes nos reatores contendo acetato, detectadas pelo FISH

Tabela 5.10. Relação DQO/sulfato, DQO inicial, potencial de oxi-redução, eficiência de remoção de DQO e sólidos totais voláteis dos reatores em batelada contendo etanol......... 60 Tabela 5.11. Velocidade máxima de produção de metano e concentração máxima de metano nos reatores contendo etanol.

Tabela 5.12. Consumo de sulfato, início do tempo de detecção de sulfeto no biogás e concentração máxima de sulfeto nos reatores contendo etanol. 
Tabela 5.13. Morfologias observadas nos reatores contendo etanol.

Tabela 5.14. Porcentagens de microrganismos obtidos com o FISH nos reatores controle e com oxigênio contendo etanol

Tabela 5.15. Morfologias das células predominantes nos reatores contendo etanol detectado por FISH

Tabela 5.16. Relação DQO/sulfato, DQO inicial, potencial de oxi-redução, eficiência de remoção de DQO e sólidos totais voláteis dos reatores em batelada contendo lactato de sódio

Tabela 5.17. Velocidade máxima de produção de metano e concentração máxima de metano nos reatores contendo lactato de sódio

Tabela 5.18. Consumo de sulfato, início do tempo de detecção de sulfeto no biogás e concentração máxima de sulfeto nos reatores contendo lactato de sódio

Tabela 5.19. Caracterização morfológica dos reatores contendo lactato.

Tabela 5.20. Porcentagens de microrganismos obtidos com o FISH nos reatores controle e com oxigênio contendo lactato.

Tabela 5.21. Morfologias das células predominantes nos reatores contendo lactato detectadas pelo FISH.

Tabela 5.22. Comparação dos resultados de produção de metano e consumo de sulfato dos reatores contendo acetato, etanol e lactato.

Tabela 5.23. Comparação dos resultados obtidos com FISH, nos reatores contendo acetato, etanol e lactato 


\section{SUMÁRIO}

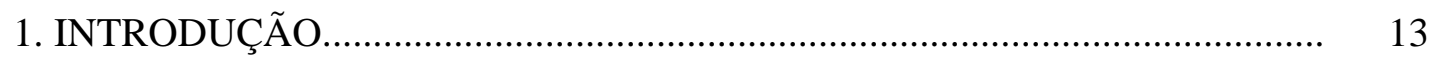

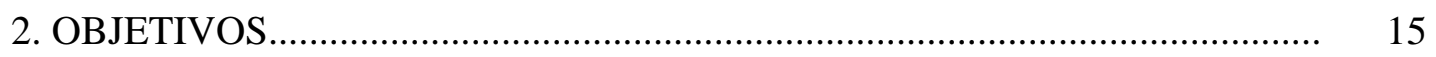

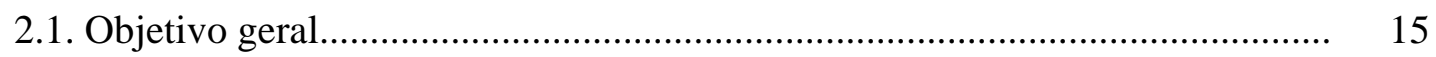

2.2. Objetivos específicos................................................................................. 15

3. REVISÃO BIBLIOGRÁFICA..................................................................... 16

3.1. Influência do oxigênio no crescimento das bactérias redutoras de 16 sulfato.

3.2. Respostas comportamentais à exposição ao oxigênio....................................... 16

3.3. Influência do oxigênio no crescimento das arqueias 23

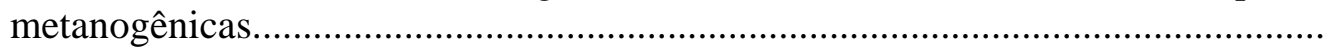

4. MATERIAL E MÉTODOS.......................................................................... 27

4.1. Fluxograma experimental............................................................................. 2

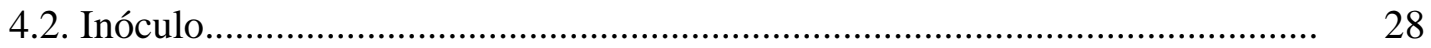

4.3. Reatores em batelada................................................................................ 28

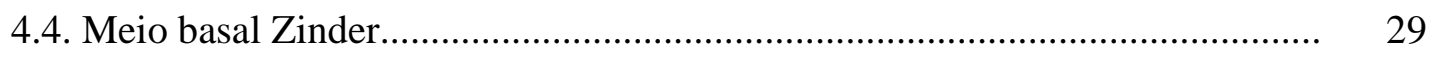

4.5. Solução de substratos orgânicos..................................................................... 32

4.5.1. Solução de acetato de sódio....................................................................... 32

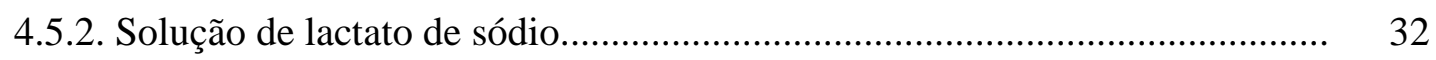

4.5.3 Solução de etanol..................................................................................... 32

4.6. Solução de sulfato de sódio........................................................................... 32

4.7. Inoculação dos reatores em batelada..................................................................... 32

4.8. Análises físico-químicas................................................................................ 33

4.8.1. Determinação de sulfato............................................................................... 33 
4.8.2. Determinação do potencial de oxi-redução e oxigênio dissolvido.

4.9. Análises cromatográficas.

4.9.1. Determinação de metano e sulfeto................................................................. 35

4.9.2. Determinação de ácidos orgânicos e álcool.................................................. 35

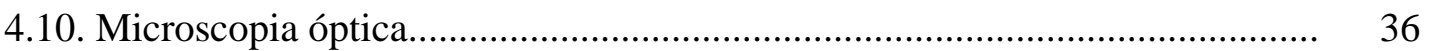

4.11. Hibridação fluorescente in situ .......................................................................... 37

4.11.1. Preparação e fixação das amostras................................................................. 38

4.11.2. Tratamento das lâminas de vidro.................................................................... 39

4.11.3. Hibridação.................................................................................................... 39

5. RESULTADOS E DISCUSSÃO.................................................................. 42

5.1. Reatores em batelada contendo acetato de sódio............................................. 42

5.1.2. Caracterização microbiana............................................................................. 49

5.2. Reatores em batelada contendo etanol............................................................. 59

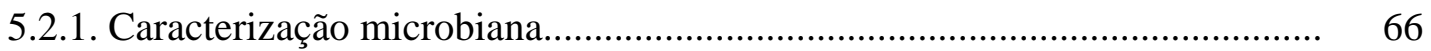

5.3. Reatores em batelada contendo lactato de sódio............................................... 70

5.3.1. Caracterização microbiana......................................................................... 78

5.4. Comparação do desempenho dos reatores anaeróbios em 84 batelada.

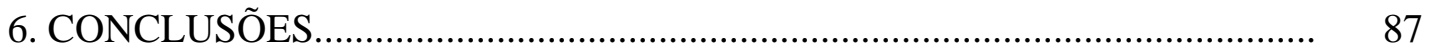

7. RECOMENDAÇÕES................................................................................ 88

8. REFERÊNCIAS BIBLIOGRÁFICAS........................................................... 89

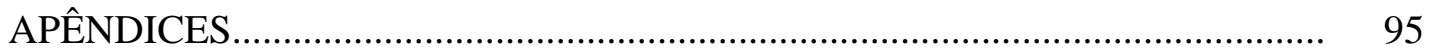

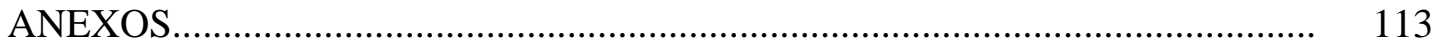




\section{INTRODUÇÃO}

Apesar do desenvolvimento tecnológico dos processos anaeróbios de tratamento de efluentes, persiste ainda uma questão, relacionada ao desempenho dos reatores em função dos possíveis efeitos da entrada de oxigênio dissolvido. Acreditava-se que a possível presença de oxigênio dissolvido nos reatores anaeróbios causaria problemas nos sistemas, entretanto, muitos efluentes podem conter oxigênio dissolvido. Reatores como UASB (Reator Anaeróbio de Manta de Lodo) operam com altas cargas hidráulicas, desse modo, níveis elevados de oxigênio podem entrar no sistema (KATO et al., 1997).

Os compostos que são gerados na redução química e metabólica do oxigênio são altamente tóxicos e reativos (JENNEY Jr. et al., 1999). Segundo Madigan et al. (1997), as formas tóxicas do oxigênio incluem o ânion superóxido $\left(\mathrm{O}_{2}^{-}\right)$, peróxido de hidrogênio $\left(\mathrm{H}_{2} \mathrm{O}_{2}\right)$ e íon hidroxila $\left(\mathrm{OH}^{-}\right)$.

Jenney Jr. et al. (1999) salientam que os compostos gerados na redução do oxigênio, também são tóxicos para os organismos aeróbios, entretanto estes possuem as enzimas superóxido dismutase, peroxidase e catalase, que participam de mecanismos de proteção contra os efeitos tóxicos. Os mesmos autores sugerem, ainda, que os organismos anaeróbios geralmente não possuem essas enzimas, mas possuem uma outra enzima responsável pelo mecanismo de defesa; ou seja, a superóxido redutase.

De acordo com Madigan et al. (1997) e Jenney Jr. et al. (1999), foi observado em Pyrococcus furiosus a presença de uma enzima denominada de superóxido redutase, responsável pela remoção do ânion superóxido, por meio da sua redução a peróxido de hidrogênio, sem haver produção de oxigênio. O peróxido de hidrogênio seria clivado por enzimas peroxidase, que geram água como produto final (MADIGAN et al., 1997).

Todavia, os microrganismos variam quanto suas necessidades ou tolerância ao oxigênio. São divididos em vários grupos, dependendo dos efeitos do oxigênio. Os organismos aeróbios são capazes de crescer na concentração de saturação de oxigênio e muitas espécies toleram valores ainda mais elevados. Por outro lado, as arquéias metanogênicas são anaeróbias estritas e não crescem na presença de oxigênio.

As bactérias redutoras de sulfato (BRS) representam outro grupo de microrganismos presentes nos processos biológicos de tratamento de efluentes. Por muitos anos, foi considerado um grupo de microrganismos anaeróbios e especializado, que utilizava quantidade limitada de 
substratos, os quais eram oxidados, incompletamente. Entretanto, tal visão mudou drasticamente com as pesquisas realizadas por Widdel, a partir de 1981 e 1982. Esse autor descobriu representante que utilizava ampla variedade de substratos orgânicos os quais eram oxidados completamente. Nos dias de hoje, os estudos salientam que as BRS também reduzem diferentes fontes de enxofre, tais como sulfato, sulfito, tiossulfato e enxofre elementar, além de nitrato e nitrito (CYPIONKA, 2000). Além dessas possibilidades, alguns representantes do grupo BRS, como, por exemplo, Desulfovibrio que possui capacidade de reduzir oxigênio utilizando os mesmos substratos orgânicos usados na redução de sulfato, tais como hidrogênio, lactato, acetato, álcoois, entre outros. Além disso, conseguem oxidar compostos reduzidos de enxofre, como sulfeto, na respiração aeróbia. Os doadores de elétrons utilizados pelas BRS são, principalmente, compostos de baixa massa molecular e, muitos destes são produtos do processo de fermentação bacteriana da degradação de carboidratos, proteínas e outros compostos. Entretanto, os doadores de elétrons mais importantes são o hidrogênio, acetato, lactato e propionato (HOLMER e STORKHOLM, 2001).

Na presença de oxigênio, as BRS e arquéias metanogênicas, não apresentam crescimento celular, isto é, aumento de biomassa; entretanto, também não morrem pelo simples contato com oxigênio. A metanogênese e redução de sulfato podem ser inibidas na presença do oxigênio, todavia, quando este é esgotado do meio, a produção de metano e redução de sulfato voltam a ocorrer.

Portanto, este trabalho visou avaliar a dinâmica de produção de metano e redução de sulfato, além da proporção dos diferentes microrganismos (bactérias, arquéias metanogênicas e bactérias redutoras de sulfato) em reatores de batelada contendo substratos orgânicos (acetato, etanol e sulfato) na presença e ausência de oxigênio. Desse modo, pretendeu-se contribuir com informações fisiológicas e bioquímicas desses microrganismos visando oferecer subsídios para entendimento do processo e aplicação da tecnologia anaeróbia. 


\section{OBJETIVOS}

\subsection{Objetivo geral}

O objetivo geral dessa pesquisa foi analisar a influência do oxigênio na dinâmica de produção de metano, redução de sulfato e consumo de matéria orgânica em reatores contendo acetato de sódio, etanol e lactato de sódio, separadamente, na presença de sulfato, sob condições mesofílicas.

\subsection{Objetivos específicos}

Os objetivos específicos desse trabalho foram:

- Verificar o consumo dos substratos orgânicos nos reatores anaeróbios em batelada controle e com adição de oxigênio;

- Avaliar a produção de metano e a redução de sulfato nos reatores em batelada;

- Caracterizar morfologicamente os microrganismos crescidos nos reatores em batelada, por meio de microscopia óptica de contraste de fase;

- Quantificar as populações microbianas nos reatores em batelada por meio da técnica de hibridação fluorescente in situ (FISH). 


\section{REVISÃO BIBLIOGRÁFICA}

\subsection{Influência do oxigênio no crescimento das bactérias redutoras de sulfato}

Dilling e Cypionka (1990) estudaram a utilização de oxigênio por Desulfovibrio desulfuricans. Os organismos foram incubados em frascos contendo hidrogênio ou lactato como doadores de elétrons, ausência de sulfato e sulfeto, e apenas $50 \mu \mathrm{M}$ de tiossulfato como fonte de enxofre. O headspace foi preenchido com $80 \%$ (v/v) de hidrogênio e 20\% de $\mathrm{CO}_{2}$. Em intervalos, foi adicionado o total de $25 \mathrm{~mL}$ (1 mmol) de oxigênio no headspace nos frascos sob agitação. Os autores verificaram que 5 ou $10 \mathrm{~mL}$ de oxigênio foram consumidos em um ou dois dias, sem aumento da biomassa. Todavia, os autores não estavam certos se o oxigênio havia sido consumido na redução do tiossulfato a sulfeto, uma vez que o tiossulfato estava presente no meio em pequena concentração (50 $\mu \mathrm{M})$.

Dannenberg et al. (1992) compararam a capacidade de respiração aeróbia com utilização de vários substratos orgânicos no crescimento de BRS provenientes de água doce e ambiente marinho. Foram utilizados como doadores de elétrons hidrogênio adicionado como gás no headspace $\left(\mathrm{H}_{2} / \mathrm{CO}_{2} 80 / 20\right.$, v/v), lactato de sódio, piruvato, formiato, etanol, acetato, propionato e butirato. Sulfato de sódio (20 mM), nitrato (10 mM) e oxigênio foram utilizados como aceptores de elétrons. O oxigênio foi adicionado por meio da adição de tampão fosfato de potássio saturado de oxigênio contendo 1,17 mM de oxigênio.

Todas as 14 linhagens de BRS estudadas por Dannenberg et al. (1992) foram capazes de reduzir o oxigênio com pelo menos um substrato, sendo os mesmos normalmente utilizados na redução do sulfato. Assim, hidrogênio, formiato, lactato, piruvato, etanol, acetato, propionato, butirato como também sulfito, tiossulfato e sulfeto foram os doadores de elétrons para a redução do oxigênio. Os organismos estudados também foram capazes de oxidar sulfeto, sulfito e tiossulfato a sulfato, tendo como aceptor de elétrons o oxigênio. Os autores observaram também que a capacidade de redução do oxigênio foi mais freqüente nas BRS de água doce do que nas espécies marinhas, o que, segundo ainda os mesmos autores, pode ser uma adaptação à limitação de sulfato que ocorre em ambientes de água doce, mas não nos marinhos.

Marschall et al. (1993) demonstraram a influência do oxigênio na redução de compostos inorgânicos de enxofre em culturas puras de dez linhagens de BRS, e também a influência no 
crescimento celular, viabilidade e mobilidade das células em culturas homogeneamente aeradas e com gradientes de oxigênio-sulfeto (estratificação de oxigênio e sulfeto).

Nos ensaios com culturas homogeneamente aeradas, os organismos foram cultivados em frascos de $500 \mathrm{~mL}$, com meio contendo acetato (2 mM) e tiossulfato. O headspace foi preenchido com mistura de $\mathrm{H}_{2} / \mathrm{CO}_{2}$ (80/20, v/v) e adição de oxigênio com utilização de seringa. Os frascos permaneceram sob agitação e temperatura de $29^{\circ} \mathrm{C}$. Os ensaios com gradiente de oxigênio-sulfeto foram realizados em tubos de vidro preenchidos até a metade com meio mineral sem adição de sulfato, contendo agar $(0,36 \%, \mathrm{~m} / \mathrm{v})$, lactato $(20 \mathrm{mM})$, resazurina $(1 \mathrm{mg} / \mathrm{L})$ e $\mathrm{Na}_{2} \mathrm{~S}(250 \mu \mathrm{M})$, inoculados com aproximadamente $10^{7}$ células/mL. A fase gasosa consistiu de $20 \%$ de dióxido de carbono e quantidades variadas de nitrogênio e oxigênio.

Nas culturas homogeneamente aeradas, a redução do sulfato, sulfito e tiossulfato foram sensíveis ao oxigênio em concentrações acima de $15 \mu \mathrm{M}$. Nessas condições não foi observada a formação de sulfeto. Nas culturas com a formação de gradiente de oxigênio-sulfeto, todas as espécies de BRS cresceram em pequenas colônias, formando faixas claras próximas à interface entre a região aerada e anaeróbia. Quanto ao aumento de biomassa, nas culturas homogeneamente aeradas somente três linhagens estudadas (Desulfovibrio desulfuricans Essex, $D$. desulfuricans CSN e Desulfobacterium autotrophicum) apresentaram pequeno crescimento celular. No ensaio com gradiente de oxigênio-sulfeto todas as linhagens estudadas apresentaram crescimento celular, isto é, aumento de biomassa.

Krekeler e Cypionka (1995) estudaram o crescimento de Desulfovibrio desulfuricans CSN utilizando sulfato, tiossulfato, sulfito, nitrito, nitrato e oxigênio como aceptores de elétrons. Os organismos foram cultivados em quimiostato contendo $\mathrm{H}_{2} / \mathrm{CO}_{2}(80 / 20, \mathrm{v} / \mathrm{v})$, acetato $(2 \mathrm{mM})$, sulfato $(20 \mathrm{mM})$ e temperatura de $30^{\circ} \mathrm{C}$.

Desulfovibrio desulfuricans catalisou a redução de seis diferentes aceptores de elétrons com hidrogênio como doador de elétrons. As maiores velocidades de redução foram observadas com o oxigênio como aceptor (1050 nmol elétrons transferidos/min.mg proteína), seguido por nitrato (680 nmol elétrons transferidos/min.mg proteína) e nitrito (410 nmol elétrons transferidos/min.mg proteína). Por outro lado, os diferentes compostos de enxofre (sulfato, sulfito e tiossulfato) apresentaram as menores velocidades, respectivamente de 140, 180 e $40 \mathrm{nmol}$ elétrons transferidos/min.mg proteína. Os mesmos autores também observaram que na ausência de hidrogênio, sulfito e tiossulfato foram desproporcionados a sulfeto e sulfato. Além disso, o 
sulfeto foi oxidado tendo nitrato e nitrito como doadores de elétrons, sulfato e amônia como produtos finais.

Segundo Madigan et al. (1997) a desproporcionação corresponde a clivagem de um composto em dois novos, onde um deles é mais oxidado que o substrato original, e o outro, mais reduzido. As reações (1) e (2) mostram a desproporcionação do tiossulfato e sulfito, respectivamente, gerando sulfato e sulfeto como produtos. Essas reações foram extraídas de Dilling e Cypionka (1990).

$$
\begin{aligned}
& \mathrm{S}_{2} \mathrm{O}_{3}{ }^{2-}+\mathrm{H}_{2} \mathrm{O} \longrightarrow \mathrm{HS}^{-}+\mathrm{SO}_{4}{ }^{2-}+\mathrm{H}^{+} \\
& 4 \mathrm{HSO}_{3}{ }^{-} \longrightarrow \mathrm{HS}^{-}+3 \mathrm{SO}_{4}{ }^{2-}+3 \mathrm{H}^{+}
\end{aligned}
$$

Em estudo realizado com biomassa microbiana do Lago Solar (Sinai), Krekeler et al. (1997) isolaram nova espécie de BRS, Desulfovibrio oxyclinae que na presença de oxigênio (adição de $30 \mu \mathrm{M}$ ) apresentou respiração aeróbia, com velocidade de 260 nmol $\mathrm{O}_{2} /$ minuto.mg proteína. Tal velocidade foi a maior encontrada para respiração aeróbia de BRS marinhas. Além disso, $D$. oxyclinae oxidou hidrogênio, lactato, sulfeto e sulfito na presença de oxigênio. Sob condições anaeróbias apresentou crescimento celular com sulfato, sulfito e tiossulfato como aceptores de elétrons utilizando hidrogênio, lactato, piruvato, etanol, propanol e butanol como doadores de elétrons. Na ausência de doadores de elétrons o organismo isolado apresentou crescimento celular por meio da desproporcionação do sulfito ou tiossulfato a sulfato e sulfeto e fermentação do piruvato. O DNA da amostra foi extraído e o gene do RNAr 16S foi amplificado por PCR (Reação de Polimerase em cadeia), em seguida o produto da PCR foi seqüenciado. Com base na árvore filogenética resultante, a linhagem estudada pertenceu a Desulfovibrio sp., sendo considerada uma nova espécie, denominada Desulfovibrio oxyclinae.

Sass et al. (1997) isolaram 28 linhagens de BRS de sedimento do Lago Stechlin, localizado próximo a Berlim. Dessas, 14 foram isoladas de sedimento coletado a $50 \mathrm{~cm}$ de profundidade e 15 linhagens de sedimento coletado a $32 \mathrm{~m}$. Para avaliação do consumo dos substratos orgânicos, os organismos foram incubados em tubos fechados contendo meio de cultura e doadores de elétrons em concentrações entre 5 mM e 20 mM, e 10 mM de aceptores de elétrons. Foram utilizados como doadores de elétrons hidrogênio, formiato, lactato, etanol, 
fumarato, malato, metanol, acetato e propionato, e como aceptores de elétrons sulfato, tiossulfato e nitrato. A respiração aeróbia e redução de sulfato foram analisadas por meio de microeletrodos e o crescimento celular por meio da turbidez (absorbância).

Os autores observaram que das 13 linhagens isoladas do sedimento coletado a $50 \mathrm{~cm}$ de profundidade, 12 possuíam características típicas de Desulfovibrio sp., ou seja, presença de desulfoviridina, células móveis e capacidade de utilizar hidrogênio e lactato. Em amostras coletadas a $32 \mathrm{~m}$ de profundidade, foram observados organismos semelhantes a Desulfovibrio sp., além de Desulfotomaculum orientis, que foi identificado pela sua capacidade de oxidar metanol e formar endósporos. A maior parte das linhagens isoladas do sedimento coletado a $50 \mathrm{~cm}$ de profundidade (12 linhagens) foi capaz de realizar redução do oxigênio, utilizando principalmente hidrogênio, formiato e lactato. O mesmo foi observado com as linhagens isoladas do sedimento a 32 m de profundidade; ou seja, das 15 linhagens, 12 também reduziram oxigênio utilizando hidrogênio, lactato e formiato. Ainda na presença de oxigênio, 12 das 28 linhagens estudadas realizaram a oxidação de sulfeto, sulfito e tiossulfato a sulfato, utilizando oxigênio como aceptor de elétrons. A Redução de sulfato não foi observada na presença de oxigênio.

Sigalevich e Cohen (2000) realizaram estudo para observar o crescimento de Desulfovibrio oxyclinae em co-cultura com Marinobacter sp. Tal experimento foi realizado em fermentador de 0,45 litro, com lactato (19 mM), sulfato (8 mM), pH 7,4 \pm 0,2 e temperatura de $35^{\circ} \mathrm{C}$. Os experimentos foram realizados em três diferentes condições de crescimento: (1) em condições anaeróbias na presença de sulfato (8 mM), (2) em condições microaeróbias (5\% de oxigênio) na presença de sulfato ( $8 \mathrm{mM})$ e (3) em condições microaeróbias (5\% de oxigênio), sem adição de sulfato. A quantificação de $D$. oxyclinae na co-cultura foi realizado por meio do FISH. Na condição 1, todo sulfato adicionado foi consumido; os substratos orgânicos lactato, acetato e citrato não foram totalmente consumidos; e ocorreu predominância de $D$. oxyclinae, correspondendo a $86 \%$ do total de células na co-cultura. Na condição 2, somente $55 \%$ do sulfato foi consumido; acetato também não foi totalmente consumido; em contrapartida, oxigênio, lactato e citrato foram totalmente consumidos; e a proporção de D. oxyclinae na co-cultura foi de 69,5\%. Na condição 3, o oxigênio do meio também foi todo consumido; além dele, lactato, citrato e acetato também foram consumidos. Nessa última condição, a proporção de $D$. oxylinae na cocultura foi de $34,4 \pm 1,9 \%$ e a velocidade de crescimento de $0,05 \mathrm{~h}^{-1}$. Os autores mencionaram que devido ao fato de $D$. oxyclinae ser incapaz de oxidar acetato e citrato, provavelmente, o 
consumo desses substratos foi realizado por Marinobacter sp. Além disso, provavelmente ocrescimento celular de $D$. oxyclinae ocorreu devido à energia obtida da respiração aeróbia devido ao fato do oxigênio ser o único aceptor de elétrons disponível na condição 3, isto é, na ausência de sulfato.

Fareleira et al. (2003) estudaram a influência do oxigênio no crescimento de Desulfovibrio gigas, com objetivo de conhecer suas estratégias de sobrevivência sob tais condições. Os organismos foram cultivados em frascos de dois litros, contendo meio com lactato (5 mM) e sulfato, mantidos a $35^{\circ} \mathrm{C}$ sob atmosfera contínua de gás argônio (cultura controle) e atmosfera de ar e gás argônio. O consumo de lactato foi totalmente inibido com adição de oxigênio. Quando a atmosfera era constituída de argônio o consumo foi de 7,4 nmol/min.mg massa seca, com a adição do oxigênio esse valor decaiu para zero.

No mesmo trabalho, Fareleira et al. (2003) submeteram organismos na fase exponencial, cultivados em meio contendo lactato, sulfato e concentrações de oxigênio iguais a 5, 10, 20, 40 e $120 \mu \mathrm{M}$ durante oito horas. Ensaios controle foram realizados com culturas mantidas sob atmosfera de gás argônio. Com a adição do oxigênio o crescimento cessou, isto é, a concentração de proteína tornou-se constante. Entretanto, a partir do momento em que a atmosfera tornou-se anaeróbia, as células voltaram a se multiplicar, com velocidade de crescimento igual a $0,14 \mathrm{~h}^{-1}$, valor que correspondeu a $70 \%$ do valor médio encontrado nas culturas controles, que não foram expostas ao oxigênio $\left(0,2 \mathrm{~h}^{-1}\right)$.

Kjeldsen et al. (2004) estudaram a tolerância das BRS ao oxigênio em sistemas de lodos ativados através da velocidade de redução de sulfato e quantificação dos organismos (NMP). Dois ensaios foram realizados, sendo o primeiro sob condições aeradas, por curto período de tempo, enquanto o segundo por longo período. No primeiro experimento, amostras coletadas do tanque de lodos ativados durante a fase anóxica, foram colocadas em frascos aerados com ar estéril $(0,2 \mu \mathrm{M})$ com 100\% de saturação de oxigênio durante 40 minutos. No segundo ensaio, os frascos foram mantidos sob aeração por período de $121 \mathrm{~h}$ e amostras foram retiradas no tempo zero e em 3, 9, 33, 73 e 121 h para as análises.

No primeiro experimento, a redução de sulfato iniciou-se imediatamente após a incubação dos frascos, tanto no ensaio com oxigênio quanto no controle, sem oxigênio. As velocidades de redução do sulfato observadas também foram semelhantes nos frascos aerados e no controle, com valores iguais a 2,2 e 2,1 $\mathrm{MM} \mathrm{SO}_{4}{ }^{2-} / \mathrm{h}$, respectivamente. No segundo experimento, a velocidade de 
redução de sulfato diminuiu com o aumento do tempo de exposição ao oxigênio; ou seja, 0,24 $\mu \mathrm{M} \mathrm{SO}_{4}{ }^{2-} / \mathrm{h}$ em $3 \mathrm{~h}$ até $0,04 \mu \mathrm{M} \mathrm{SO}_{4}{ }^{2-} / \mathrm{h}$ em 121 h. Entretanto, a quantidade de BRS durante todo o período de aeração (121 h) se manteve constante, em torno de $10^{6}$ células/mL, o que indicou que a diminuição da velocidade de redução de sulfato ocorreu devido a inativação metabólica temporária de grande parte da população de BRS presente na amostra (KJELDSEN, et al. 2004). Para os autores essa inativação metabólica ocorre em resposta ao stress causado por algum fator, no caso a presença de oxigênio.

Os autores (Op. cit.) constataram ainda, que a população de BRS no sistema de lodos ativados foi de $10^{6}-10^{7}$ células/mL, enquanto que, o total de células encontradas ultrapassou o valor de $10^{9}$ células/mL. Entretanto, de acordo com os resultados obtidos, provavelmente, as BRS estavam adaptadas ao oxigênio devido a capacidade de recuperação da redução de sulfato após a exposição a curtos períodos de tempo.

\subsection{Respostas comportamentais à exposição ao oxigênio}

As BRS também exibem respostas comportamentais em relação à presença de oxigênio (Cypionka, 2000). Segundo o mesmo autor, três diferentes respostas podem ser observadas: agregação celular, migração para ambientes sem oxigênio e formação de faixas na interface aeróbia-anaeróbia de lagos, rios e mar (CYPIONKA, 2000).

Johnson et al. (1997) realizaram estudo para verificar aerotaxia em Desulfovibrio vulgaris Hildenborough, sob concentrações crescentes de oxigênio (0,02 a 0,12\%). Para tal experimento, os autores utilizaram tubos fechados para cultura contendo $15 \mathrm{~mL}$ de meio e mistura gasosa de oxigênio, combinada com $\mathrm{H}_{2} / \mathrm{CO}_{2} / \mathrm{N}_{2}$, nas proporções $10 / 10 / 80 \%$. Essa mistura gasosa foi adicionada constantemente nos tubos de cultura durante todo o ensaio. Os autores observaram que com porcentagens reduzidas de oxigênio (0,02 a 0,04\%), D. vulgaris moveram-se em direção ao local onde havia oxigênio e realizaram respiração aeróbia. Os mesmos autores acreditam que essa aerotaxia apresentada por $D$. vulgaris foi primordialmente um mecanismo de defesa contra a intrusão de oxigênio no meio anaeróbio.

Krekeler et al. (1998) isolaram de biomassa cianobacteriana do Lago Solar (Sinai) 4 linhagens de BRS pertencentes a Desulfovibrio, identificadas como D22, N13, N33 e N24. A biomassa foi dividida em duas partes, de acordo com a profundidade, a primeira de 0 - $3 \mathrm{~mm}$ e outra de $3-6 \mathrm{~mm}$. A camada superior $(0-3 \mathrm{~mm})$ permaneceu oxigenada durante o dia e 
anaeróbia à noite. Todavia, a camada inferior $(3-6 \mathrm{~mm})$ permaneceu anaeróbia durante dia e noite. As linhagens foram cultivadas em meio contendo lactato $(10 \mathrm{mM}), 1 \mathrm{mM}$ de $\mathrm{FeSO}_{4}$ e 1 $\mathrm{mM}$ de tioglicolato. As amostras foram homogeneizadas e transferidas para tubos de NMP, os quais foram incubados a $30^{\circ} \mathrm{C}$ por três meses. A difusão de oxigênio para dentro dos tubos foi permitida pela utilização de tampas de borracha permeáveis.

A quantidade de BRS na camada superior foi 100 vezes menor durante o dia $\left(10^{4}\right.$ células $/ \mathrm{mL})$ que à noite $\left(10^{6}\right.$ células $\left./ \mathrm{mL}\right)$, enquanto que, na camada inferior, esse valor foi maior durante o dia $\left(10^{6}\right.$ células $\left./ \mathrm{mL}\right)$ e menor à noite $\left(10^{5}\right.$ células $\left./ \mathrm{mL}\right)$. Segundo os autores, tal fato indicou que as BRS da camada superior migraram para a camada inferior durante o dia por causa do gradiente de oxigênio, ou os organismos formaram agregados celulares na camada superior, ocasionando menor concentração de organismos nesta camada.

Krekeler et al. (1998) observaram também formação de faixas de organismos (pertencentes a linhagem N13) ao redor das bolhas de oxigênio, localizadas na interface aeróbiaanaeróbia. Com o passar do tempo de incubação, os autores observaram que as bolhas tornaramse menores, indicando consumo do oxigênio.

Teske (1998) investigou a presença de BRS em biomassa cianobacteriana e suas relações com o oxigênio presente no ambiente. Amostras da biomassa foram coletadas do Lago Solar (Sinai, Egito), à profundidade de 0,6 a 0,7 m. Estas foram utilizadas para ensaios de NMP para quantificação das BRS e para medição das velocidades de redução de sulfato. A biomassa foi dividida em camadas de 0-2, 2-4, 4-7, 7-10 e 10-13 mm, para melhor distinção da profundidade da mesma.

Com base no método do NMP, o autor encontrou população ativa de BRS durante o dia na zona oxigenada $(0-2 \mathrm{~mm})$ estimada em $4,5 \times 10^{6}$ células $/ \mathrm{mL}$ e elevadas velocidades de redução de sulfato $\left(2,207 \mathrm{nmol}\right.$ de $\mathrm{SO}_{4}{ }^{2-} / \mathrm{mL}$.dia $)$. Portanto, o oxigênio não inibiu significativamente a redução de sulfato, uma vez que o valor encontrado correspondeu a $70 \%$ da maior velocidade de redução de sulfato encontrada na biomassa cianobacteriana (TESKE, 1998).

Segundo o autor (Op. cit.), essa elevada atividade da população de BRS na zona oxigenada sugeriu que essas bactérias desenvolveram estratégias adaptativas para crescerem na presença de oxigênio, o que incluiu a respiração com oxigênio, mobilidade e formação de agregados e co-culturas. 
Eschemann et al. (1999) analisaram a aerotaxia de Desulfovibrio desulfuricans e Desulfovibrio oxyclinae, em relação à presença de oxigênio. Os organismos foram cultivados em meio contendo lactato $(20 \mathrm{mM})$ e sulfato $(20 \mathrm{mM})$, a $30^{\circ} \mathrm{C}$. Resazurina $(1 \mu \mathrm{M})$ foi adicionada como indicador do potencial redox e solução redutora de ditionito de sódio. A aerotaxia foi observada em tubos capilares, os quais foram preenchidos com o meio, células suspensas e $5 \mu \mathrm{L}$ de oxigênio introduzido com auxílio de seringa Hamilton. Os autores observaram a formação de faixas de BRS (agregados celulares) ao redor das bolhas de oxigênio. As células presentes no interior da faixa tornaram-se rosa devido ao potencial redox oxidado, enquanto que as células presentes na parte externa permaneceram transparentes, devido ao potencial redox reduzido. O oxigênio das bolhas foi totalmente consumido durante a noite, restando apenas pequena bolha, provavelmente de nitrogênio. A formação das faixas dependeu da presença de um doador de elétrons e do oxigênio, ou seja, em ensaios realizados sem a adição de lactato não houve a formação das faixas ao redor das bolhas de oxigênio.

Ainda no mesmo estudo, em experimento controle, sem adição de oxigênio, somente sob atmosfera de nitrogênio, não houve a formação das faixas. Em relação à mobilidade, Eschemann et al. (1999) verificaram que Desulfovibrio desulfuricans e Desulfovibrio oxyclinae quando expostas ao oxigênio, não se locomoveram em direção à zona anaeróbia, como era esperado para organismo anaeróbio estrito. Ao invés disso, acumularam-se na zona oxigenada, na qual a concentração de oxigênio era de $20 \%(50 \mu \mathrm{M})$ do ar saturado. Segundo os autores, esse comportamento foi relacionado com a estratégia para remover o oxigênio do meio e restabelecer a condição anaeróbia.

\subsection{Influência do oxigênio no crescimento das arquéias metanogênicas}

Lens et al. (1994) avaliaram a produção de metano em reator aeróbio (biofiltros, lodos ativados e de discos rotativos) e anaeróbio (reator de fluxo ascendente e manta de lodo - UASB). Um dos reatores de lodos ativados era aerado com oxigênio puro (40 mg/L de OD) e outro com ar. Os ensaios foram realizados em tubos de $20 \mathrm{~mL}$, preenchidos com meio basal, acetato de sódio (200 mg/L) e headspace preenchido com $\mathrm{H}_{2} / \mathrm{CO}_{2}$ (80/20\%) para favorecer o crescimento de arquéias metanogênicas acetoclásticas e hidrogenotróficas.

Segundo Lens et al. (1994), foi verificada produção de metano, após duas semanas de incubação, nos frascos inoculados com biomassa dos lodos ativados, biofiltro e discos rotativos. 
Entretanto, a velocidade de produção de metano nesses frascos correspondeu a menos de $1 \%$ da velocidade observada no UASB (40666 $\pm 2082 \mu \mathrm{L} \mathrm{CH} / \mathrm{g} \mathrm{SV}$.d). Somente nos frascos inoculados com biomassa retirada do reator de lodos ativados com oxigênio puro não foi verificada produção de metano, mesmo após dois meses de operação. Os autores atribuíram a existência de arquéias metanogênicas em reatores aeróbios à existência de micronichos anaeróbios, tais como biofilmes e flocos, uma vez que oxigênio consegue penetrar até $100 \mu \mathrm{m}$ no biofilme, além da versatilidade fisiológica desses organismos.

Zitomer (1997) estudou a conversão de substrato orgânico por culturas mistas de bactérias aeróbias e arquéias metanogênicas, na presença de oxigênio. Os ensaios em batelada foram realizados em frascos de $160 \mathrm{~mL}$, contendo meio basal, propionato e etanol como substratos orgânicos. Lodo anaeróbio proveniente de estação de tratamento de esgoto sanitário foi utilizado como inóculo, sendo adicionado $50 \mathrm{~mL}$ em cada frasco. Resazurina foi utilizada como indicador do potencial redox. O headspace foi preenchido com gás metano. Para cada substrato utilizado, um reator foi mantido anaeróbio, como controle; outro recebeu $10 \mathrm{~mL}$ de ar por dia (com auxílio de seringa) e outro recebeu $30 \mathrm{~mL}$ de ar por dia. Os reatores foram incubados a $35^{\circ} \mathrm{C}$, sob agitação, no escuro.

Zitomer (1997) observou que os organismos mantiveram-se em suspensão, e não formando flocos ou aglomerados que poderiam formar micronichos anaeróbios para as arquéias metanogênicas. Os autores também observaram que nos primeiros trinta minutos após adição do oxigênio, o potencial redox dos frascos estava oxidado (resazurina com coloração rosa), indicando presença do oxigênio. Entretanto, após esse período, o potencial redox tornou-se reduzido (resazurina tornou-se transparente), restando de 0,6 a 1\% de oxigênio no headspace. $\mathrm{O}$ autor atribuiu o consumo do oxigênio à presença de bactérias aeróbias que oxidam metano (metanotróficas). Com relação à remoção de DQO, o autor observou que cerca de 45 a 95\% foi removida por metanogênese. Assim, o autor concluiu que as arquéias metanogênicas não morrem na presença de oxigênio, todavia seu crescimento pode ser inibido. Após o consumo do oxigênio por organismos aeróbios, as arquéias metanogênicas passam a reduzir o substrato orgânico produzindo metano.

Zitomer e Shrout (1998) estudaram a metanogênese e a redução do oxigênio em culturas mistas. O inóculo utilizado foi oriundo de reatores anaeróbios utilizados no tratamento de esgoto sanitário. Os autores usaram frascos de soro de $160 \mathrm{~mL}$, nos quais foram adicionados $50 \mathrm{~mL}$ de 
inóculo, $10 \mathrm{~mL}$ de meio contendo sacarose (5-80 g/L), amônia, fósforo, nutrientes e resazurina. Gás metano foi adicionado nos frascos e fechados em seguida. A cada dois dias $10 \mathrm{~mL}$ de cultura eram retiradas e mesmo volume de meio novo adicionado. Duas condições de adição de oxigênio nos frascos foram testadas. Na primeira condição, o oxigênio foi adicionado no momento da adição do meio nos reatores, definido como ensaio com culturas aeróbias/anaeróbias. Na segunda condição, o oxigênio foi adicionado no dia seguinte da adição do meio, portanto, foi denominado ensaio com culturas anaeróbias/aeróbias. O oxigênio foi adicionado por meio de seringa, em volumes iguais a 4, 12 e $48 \mathrm{~mL}$, a cada dois dias. Um reator controle foi mantido sob condições anaeróbias. Todos os reatores foram mantidos a $35^{\circ} \mathrm{C}$, sob agitação, no escuro.

Zitomer e Shrout (1998) observaram que nos reatores controle e naqueles com 4 e $12 \mathrm{~mL}$ de oxigênio, a resazurina ficou transparente (potencial redox reduzido) e, portanto, não indicou a sua presença no meio. Apenas durante os primeiros trinta minutos após a adição do oxigênio, a resazurina apresentou coloração rosa (potencial redox oxidado), indicando presença do mesmo. Em contrapartida, nos reatores onde foram adicionados $48 \mathrm{~mL}$ de oxigênio, a solução permaneceu rosa (potencial redox oxidado). A atividade metanogênica específica foi calculada, e os maiores valores foram encontrados nos frascos com $48 \mathrm{~mL}$ de oxigênio (1,2 mL biogás/g SSV. d), enquanto nos reatores com $4 \mathrm{~mL}$ de oxigênio, foi observado atividade de 0,8 mL biogás/g SSV. d. Embora nos reatores com $48 \mathrm{~mL}$ de oxigênio terem sido observados os maiores valores de atividade metanogênica específica, a quantidade produzida de metano foi menor (15 mL), comparando-se com os reatores com $4 \mathrm{~mL}$ de oxigênio, nos quais foram produzidos $20 \mathrm{~mL}$ de metano. Os autores atribuem a menor quantidade de metano nos frascos com maior quantidade de oxigênio à oxidação do metano por bactérias metanotróficas, que são organismos aeróbios.

Zitomer e Shrout (1998), ainda no mesmo estudo, não observaram a presença de grânulos, flocos ou qualquer tipo de aglomerado celular que poderiam formar micronichos anaeróbios para as metanogênicas. Eles acreditam que na presença do oxigênio ocorreu oxidação aeróbia de intermediários como ácido propiônico, ácido acético e hidrogênio. Assim, a menor concentração desses intermediários no sistema pode explicar a maior atividade dos organismos metanogênicos nos reatores com oxigênio.

Estrada-Vázquez et al. (2003) avaliaram a influência da concentração de substrato orgânico (sacarose) na resistência ao oxigênio de biomassa metanogênica suspensa. O lodo utilizado foi retirado de reatores contínuos, em escala de bancada, alimentados com água 
residuária sintética contendo $25 \mathrm{~g} / \mathrm{L}$ de DQO. Os reatores foram alimentados com várias concentrações de sacarose (0, 1, 2 e 4 g/L de DQO), sob proporções crescentes de oxigênio no headspace $(0 ; 2,5 ; 5 ; 10 ; 20 ; 50$ e 70\% v/v). Foram utilizados frascos de soro de $160 \mathrm{~mL}$, como reatores, com $60 \mathrm{~mL}$ de volume reacional e $100 \mathrm{~mL}$ de headspace. Os reatores foram incubados a $35^{\circ} \mathrm{C}$, sob agitação de $80 \mathrm{rpm}$, durante três dias. Após esse período, o meio foi trocado por outro contendo acetato de sódio $30 \mathrm{mmol} / \mathrm{L}$ e o headspace preenchido com $\mathrm{N}_{2} / \mathrm{CO}_{2}$ (4/1), para determinação da atividade metanogênica específica. Os autores calcularam a taxa de recuperação do lodo (R) após a incubação com oxigênio, pela divisão entra a atividade metanogênica específica da cultura após exposição ao oxigênio, pela atividade metanogênica específica do controle, em porcentagem.

Os autores (Op. Cit.) verificaram que o aumento da concentração de sacarose aumentou significativamente a resistência do lodo ao oxigênio. A taxa de recuperação (R) atingiu 95\% para concentrações de 1 e 2 g/L de sacarose. Estrada-Vázquez et al. (2003) observaram também que a exposição ao oxigênio em culturas sem adição de sacarose afetou drasticamente a produção de metano. Nos reatores controle a concentração máxima de metano chegou a $0,08 \mathrm{mmol} /$ reator, enquanto que nos frascos com oxigênio foi observado $0,01 \mathrm{mmol} /$ reator. Nos ensaios com adição de 2 e 4 g/L de sacarose, o efeito do oxigênio na produção de metano foi menor. Em proporções menores de oxigênio (0; 2,5 e 5\%), as concentrações observadas de metano foram semelhantes a dos reatores controle. Os autores concluíram que organismos facultativos presentes nos sistemas utilizaram o substrato orgânico na respiração aeróbia, retirando oxigênio do meio, evitando assim, a inibição das arquéias metanogênicas. 


\section{MATERIAL E MÉTODOS}

\subsection{Fluxograma experimental}

Na realização dos experimentos foi utilizado como inóculo lodo granular proveniente de reator anaeróbio de fluxo ascendente e manta de lodo (UASB) utilizado no tratamento de água residuária de abatedouro de aves. Foram utilizados reatores em batelada, contendo meio basal ZINDER, acrescido de solução de metais traço, vitaminas, substratos orgânicos (acetato de sódio, etanol e lactato de sódio) e solução de sulfato de sódio, como fonte de enxofre. As concentrações dos substratos orgânicos e do sulfato de sódio foram calculadas para se obter a relação DQO/sulfato de aproximadamente 1,1-1,5. Tal relação foi escolhida para favorecer a sulfetogênese.

Os reatores foram alimentados com acetato de sódio (757,7 mg/L)/sulfato de sódio (960 mg/L), etanol (540,6 mg/L)/sulfato de sódio (967 mg/L) e lactato de sódio (922,5 mg/L)/sulfato de sódio (860 mg/L). Nesses reatores foi borbulhado oxigênio puro comercial no meio líquido para se obter concentração de oxigênio dissolvido de aproximadamente 3,0 - 3,5 mg/L, o que corresponde a aproximadamente metade da concentração de saturação do oxigênio na água a $25^{\circ} \mathrm{C}$, cujo valor é de aproximadamente $8 \mathrm{mg} / \mathrm{L}$. Os reatores controle anaeróbios também foram alimentados com acetato de sódio (874,5 mg/L)/sulfato de sódio (950 mg/L), etanol (454,9 $\mathrm{mg} / \mathrm{L}$ )/sulfato de sódio (907 mf/L) e lactato de sódio (1010,3 mg/L)/sulfato de sódio (920 mg/L) e submetidos a atmosfera gasosa de $\mathrm{N}_{2} / \mathrm{CO}_{2}$ (70/30\%). Todos os reatores permaneceram sob agitação de $150 \mathrm{rpm}$ e temperatura de $25^{\circ} \mathrm{C}$.

Os reatores em batelada, controle e com oxigênio, foram operados durante 960 h, 816 h e 768 h, com os substratos orgânicos acetato de sódio, etanol e lactato de sódio, respectivamente.

Para o acompanhamento das atividades microbianas foram realizadas análises físicoquímicas (sulfato, potencial redox, OD e DQO), análises cromatográficas (metano, sulfeto e ácidos orgânicos) e exames microscópicos de contraste de fase, fluorescência e FISH. A Figura 4.1 mostra o fluxograma das atividades experimentais. 


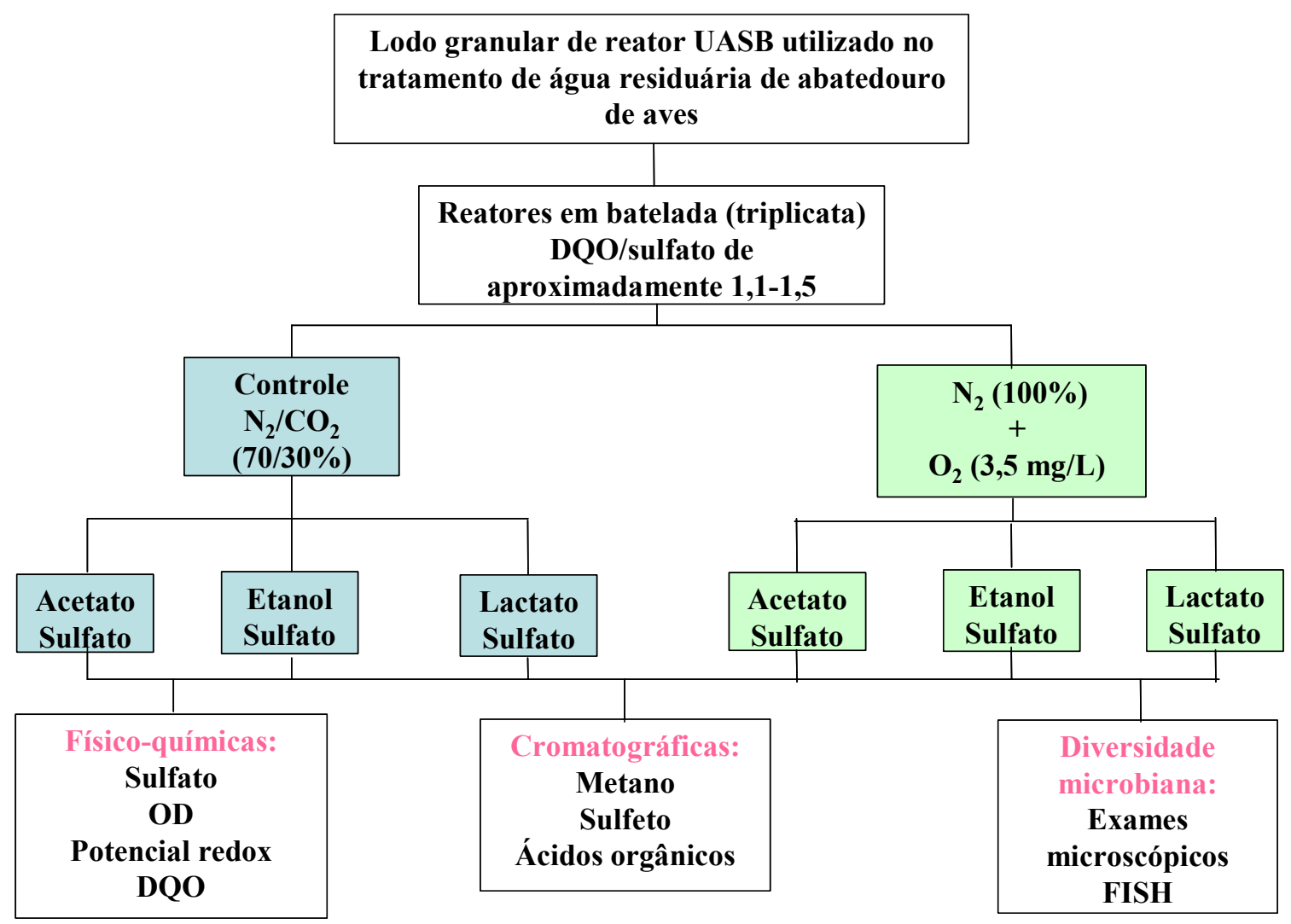

Figura 4.1 Fluxograma das atividades experimentais.

\subsection{Inóculo}

O inóculo utilizado foi proveniente de reator anaeróbio de fluxo ascendente e manta de lodo (UASB) utilizado no tratamento de água residuária de abatedouro de aves (Avícola Dacar S/A, Tietê, SP). O lodo foi mantido sob refrigeração a $4^{\circ} \mathrm{C}$ até sua utilização. Antes de ser adicionado ao reator, o inóculo foi lavado em água destilada, homogeneizado em liquidificador e realizado a análise de sólidos totais voláteis (STV), de acordo com APHA (1998). Foram utilizados 7\% (v/v) de inóculo em cada reator.

\subsection{Reatores em batelada}

Os reatores anaeróbios para os ensaios em batelada com células planctônicas foram preparados, em triplicata, em frascos Duran de $2 \mathrm{~L}$, fechados com tampas de borracha de butila e rosca plástica (Figura 4.2). Os mesmos foram mantidos sob agitação de 150 rpm (DOMINGUES, 2001) e temperatura controlada de $25^{\circ} \mathrm{C}$. A triplicata consistiu da utilização de três reatores em cada condição estudada. 
Utilizou-se o meio basal Zinder acrescido de solução traço de metais (ZINDER et al. 1984) e de vitaminas (WIDDEL e PFENNING, 1984), alimentados com acetato de sódio, etanol, lactato de sódio e sulfato de sódio sob atmosfera de oxigênio puro comercial, adicionado com auxílio de pedra microporosa. Os reatores controle também foram alimentados com os mesmos substratos orgânicos e fonte de enxofre, entretanto, submetidos a atmosfera de $\mathrm{N}_{2} / \mathrm{CO}_{2}(70 / 30 \%)$. O volume total da solução foi de $1200 \mathrm{~mL}$ e do headspace de $800 \mathrm{~mL}$.

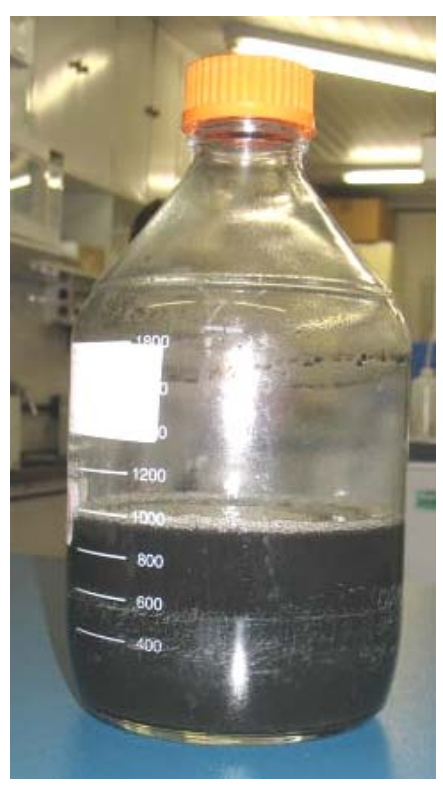

Figura 4.2 Reator em batelada

\subsection{Meio Basal Zinder}

Foi utilizado no cultivo dos microrganismos o meio basal Zinder (ZINDER et al. 1984). O meio de cultivo foi preparado pela dissolução dos seus componentes em água ultrapurificada, na ordem apresentada na Tabela 4.1. Após o preparo, o meio permaneceu sob atmosfera de nitrogênio (100\%) durante 20 minutos e distribuído em frascos Duran de 2 L. Em seguida, os frascos foram fechados com tampa de butila e roscas plásticas, esterilizados em autoclave a $121^{\circ} \mathrm{C}$ e $1 \mathrm{~atm}$, durante 20 minutos, e estocados à temperatura ambiente na ausência de luz.

A solução traço de metais foi preparada pela dissolução inicial de Tritriplex em água ultrapurificada e seu pH ajustado para 7,0 com solução de KOH 10 M. Em seguida, os demais componentes foram acrescentados na solução na ordem apresentada na Tabela 4.2. Após o 
preparo, a solução foi distribuída em frascos de antibiótico, esterilizada em autoclave a $121^{\circ} \mathrm{C}$ e 1 atm, durante 20 minutos, e mantida sob refrigeração $\left(4^{\circ} \mathrm{C}\right)$ no escuro.

Tabela 4.1. Composição do meio basal Zinder.

\section{Componentes}

\section{Quantidades - Q.S.P. $1000 \mathrm{~mL}$ de Água}

Ultrapurificada

$\begin{array}{cc}\mathrm{NH}_{4} \mathrm{Cl} & 0,5 \mathrm{~g} \\ \mathrm{KH}_{2} \mathrm{PO}_{4} & 0,4 \mathrm{~g} \\ \mathrm{MgCl}_{2} \cdot 6 \mathrm{H}_{2} \mathrm{O} & 0,1 \mathrm{~g} \\ \mathrm{CaCl}_{2} \cdot 2 \mathrm{H}_{2} \mathrm{O} & 0,05 \mathrm{~g} \\ \text { ção Traço de Metais } & 10,0 \mathrm{~mL}\end{array}$

Fonte: ZINDER et al. (1984).

Acrescentou-se também ao meio de cultivo solução de bicarbonato de sódio (10\%) e solução de vitaminas. Foi utilizado $12 \mathrm{~mL}$ de solução de bicarbonato e $12 \mathrm{~mL}$ de solução de vitaminas, para $1072 \mathrm{~mL}, 1087 \mathrm{~mL}$ e $1085 \mathrm{~mL}$ de volume reacional, nos reatores contendo acetato, etanol e lactato, respectivamente.

A solução de bicarbonato de sódio (10\%) foi preparada pela dissolução do respectivo sal em água ultrapurificada, previamente fervida e resfriada a $50^{\circ} \mathrm{C}$, mantida por 20 minutos sob fluxo de nitrogênio (100\%), esterilizada por filtração rápida pelo sistema Millipore, com filtro de membrana de 0,22 $\mu \mathrm{m}$ de porosidade, sob condições de assepsia. Todo material utilizado foi previamente autoclavado a $121^{\circ} \mathrm{C}$ e 1 atm, durante 20 minutos. Em seguida, a solução foi distribuída em frascos de antibiótico, fechados com batoques de borracha de butila, lacrados com selos de alumínio e mantidos em temperatura ambiente na ausência de luz.

A solução de vitaminas foi preparada pela dissolução dos componentes em água ultrapurificada na ordem apresentada na Tabela 4.3. A solução foi distribuída em frascos apropriados sob atmosfera de $\mathrm{N}_{2}$ (100\%). A solução foi esterilizada nas mesmas condições da solução de bicarbonato de sódio (10\%) e mantida no escuro sob refrigeração $\left(4^{\circ} \mathrm{C}\right)$. 
Tabela 4.2. Composição da solução traço de metais.

\section{Componentes}

Quantidades - Q.S.P. $1000 \mathrm{~mL}$ de Água

Ultrapurificada

\begin{tabular}{cc}
\hline Tritriplex III & $4,5 \mathrm{~g}$ \\
$\mathrm{FeSO}_{4} \cdot 7 \mathrm{H}_{2} \mathrm{O}$ & $0,556 \mathrm{~g}$ \\
$\mathrm{MnSO}_{4} \cdot \mathrm{H}_{2} \mathrm{O}$ & $0,086 \mathrm{~g}$ \\
$\mathrm{CoCl}_{2} \cdot 6 \mathrm{H}_{2} \mathrm{O}$ & $0,17 \mathrm{~g}$ \\
$\mathrm{ZnSO}_{4} \cdot 7 \mathrm{H}_{2} \mathrm{O}$ & $0,21 \mathrm{~g}$ \\
$\mathrm{H}_{3} \mathrm{BO}_{3}$ & $0,19 \mathrm{~g}$ \\
$\mathrm{NiCl}_{2}$ & $0,02 \mathrm{~g}$ \\
$\mathrm{Na}_{2} \mathrm{MoO}_{4}$ & $0,01 \mathrm{~g}$ \\
\hline \hline
\end{tabular}

Fonte: ZINDER et al. (1984).

Tabela 4.3. Composição da solução de vitaminas.

\begin{tabular}{cc}
\hline \hline Componentes & $\begin{array}{c}\text { Quantidades }- \text { Q.S.P. 1000 mL de Água } \\
\text { Ultrapurificada }\end{array}$ \\
\hline Biotina & $0,002 \mathrm{~g}$ \\
Ácido fólico & $0,002 \mathrm{~g}$ \\
Tiamina . HCl.2 $\mathrm{H}_{2} \mathrm{O}$ & $0,005 \mathrm{~g}$ \\
Piroxidina $\mathrm{HCl}$ & $0,01 \mathrm{~g}$ \\
Riboflavina & $0,005 \mathrm{~g}$ \\
Ácido nicotínico & $0,005 \mathrm{~g}$ \\
Pantotenato de cálcio & $0,0001 \mathrm{~g}$ \\
Vitamina B 12 & $0,0001 \mathrm{~g}$ \\
Ácido $p$-aminobenzóico & 0,005 \\
Ácido lipóico & $0,005 \mathrm{~g}$ \\
\hline \hline
\end{tabular}

Fonte: WIDDEL e PFENNING (1984). 


\subsection{Solução de substratos orgânicos}

Foram utilizados substratos orgânicos como acetato de sódio, lactato de sódio e etanol, separadamente, nos reatores em batelada, com sulfato de sódio.

\subsubsection{Solução de acetato de sódio}

A solução de acetato de sódio (60 g/L) foi preparada pela dissolução do respectivo sal em água ultrapurificada, distribuída em frascos de antibiótico sob fluxo de nitrogênio (100\%), fechados com batoques de borracha de butila, lacrados com selos de alumínio. Os frascos foram esterilizados a $121^{\circ} \mathrm{C}$ e $1 \mathrm{~atm}$ por 20 minutos. Os frascos foram armazenados à temperatura ambiente, na ausência de luz.

\subsubsection{Solução de lactato de sódio}

A solução de lactato de sódio (180 g/L) foi preparada através da reação de neutralização de ácido lático $4 \mathrm{M}$ e hidróxido de sódio 4 M. O pH da solução final foi ajustado para 9,8 utilizando-se a solução de hidróxido de sódio 4 M. A solução foi mantida e distribuída em frascos de antibiótico sob fluxo de nitrogênio (100\%), esterilizada a $121^{\circ} \mathrm{C}$ e $1 \mathrm{~atm}$, por 20 minutos, e armazenada à temperatura ambiente, na ausência de luz.

\subsubsection{Solução de etanol}

A solução de etanol foi preparada pela adição de 9,10 mL de etanol em $50 \mathrm{~mL}$ de água ultrapurificada estéril. Essa solução foi preparada no momento da utilização nos reatores em batelada. Utilizou-se etanol Merk com 99,9\% de pureza.

\subsection{Solução de sulfato de sódio}

O sulfato de sódio foi adicionado diretamente nos reatores em batelada na quantidade de 1,35g, valor calculado para se obter a concentração de aproximadamente $960 \mathrm{mg} / \mathrm{L}$ de sulfato nos reatores.

\subsection{Inoculação dos reatores em batelada}

Os reatores em batelada foram preenchidos com meio Zinder, solução de bicarbonato de sódio, solução de vitaminas e os substratos orgânicos (acetato de sódio, etanol e lactato de sódio), 
separadamente. A Tabela 4.4 mostra as quantidades das soluções adicionadas nos reatores. Os reatores controle tiveram headspace preenchido com mistura de $\mathrm{N}_{2} / \mathrm{CO}_{2}$ (70/30\%) e os reatores com oxigênio tiveram seu headspace primeiramente fluxionado com $\mathrm{N}_{2}$ (100\%), em seguida, oxigênio puro comercial foi borbulhado no meio líquido, utilizando-se pedra microporosa Alltech Hastaloy, de $2 \mu \mathrm{m}$ de porosidade, até obter-se a concentração de oxigênio dissolvido de 3-3,5 $\mathrm{mg} / \mathrm{L}$.

Tabela 4.4. Composição dos reatores em batelada.

Soluções

Acetato de Sódio

1072

12

12

1,35

20

(mL)

Inóculo (mL)

84

Etanol

Lactato de sódio

\begin{tabular}{cccc}
\hline $\begin{array}{c}\text { Meio Zinder (mL) } \\
\text { Solução de }\end{array}$ & 1072 & 1087 & 1085 \\
Bicarbonato de & 12 & 12 & 12 \\
$\begin{array}{c}\text { Sódio (10\%) (mL) } \\
\text { Solução de } \\
\text { Vitaminas (mL) }\end{array}$ & 12 & 12 & 12 \\
$\begin{array}{l}\text { Sulfato de Sódio (g) } \\
\text { Substrato Orgânico } \\
\quad(\mathbf{m L})\end{array}$ & 1,35 & 1,35 & 1,35 \\
Inóculo $(\mathbf{m L})$ & 20 & 5 & 6,6 \\
\hline
\end{tabular}

\subsection{Análises físico-químicas}

Foi realizado o acompanhamento temporal das concentrações de sulfato e demanda química de oxigênio (DQO) inicial e final, em amostras filtradas em membrana de fibra de vidro de 1,2 $\mu \mathrm{m}$. As análises de OD e potencial de oxi-redução foram realizadas no início e final dos experimentos, de acordo com os métodos descritos em APHA (1998).

\subsubsection{Determinação de sulfato}

O acompanhamento temporal da utilização do sulfato foi realizado por método espectrofotométrico, utilizando-se o Kit SULFAVER ${ }^{\circledR} 4$ (SULFATE REAGENT-HACH), 
através do qual o íon sulfato foi precipitado em meio ácido com cloreto de bário realizando-se a leitura de absorbância em 450 nm (APHA, 1998).

Amostras foram coletadas dos reatores em batelada com seringa esterilizada, sob condições de assepsia, centrifugadas a $10000 \mathrm{rpm}$ e filtradas em membrana de fibra de vidro de 1,2 $\mu \mathrm{m}$ de porosidade. Alíquotas de 2,5 mL das amostras foram diluídas em $50 \mathrm{~mL}$ de água destilada para a leitura da absorbância. Para a leitura do branco foram utilizadas as mesmas amostras diluídas, mas sem a precipitação com o cloreto de bário.

As velocidades de consumo de sulfato foram calculadas por meio do ajuste da equação exponencial de primeira ordem das concentrações analisadas, seguido da derivação da curva originada, utilizando o software Origin 6.0.

\subsubsection{Determinação do potencial de oxi-redução e oxigênio dissolvido}

O potencial de oxi-redução foi analisado no início e final dos ensaios nos reatores em batelada utilizando-se potenciômetro (Modelo UB-10, Denver Instruments) e eletrodo combinado de platina - referência Ag/AgCl (Modelo DMR-CP1, Digimed). O valor do potencial redox foi transformado em relação ao padrão de hidrogênio (Eh) de acordo com APHA (1998), utilizando a Equação (3):

$$
\text { Eh }(\text { sistema })=\text { E }(\text { observado })+\text { Eh }(\text { ZoBell })-\text { Eh (ZoBell observado })
$$

sendo,

Eh $($ ZoBell $)=428 \mathrm{mV}$ e Eh $($ ZoBell $)$ observado $=224 \mathrm{mV}$ a $25^{\circ} \mathrm{C}$

O oxigênio dissolvido (OD) também foi analisado no início e fim dos ensaios utilizandose eletrodo Orion modelo 810.

\subsection{Análises cromatográficas}

Análises cromatográficas foram realizadas para monitoramento do gás metano e sulfeto produzidos, e acompanhamento temporal do consumo dos ácidos orgânicos voláteis (ácido acético e ácido lático) e etanol. 


\subsubsection{Determinação de metano e sulfeto}

O monitoramento do gás metano e sulfeto foram realizados por cromatografia gasosa. As amostras foram analisadas em cromatógrafo Gow-Mac, equipado com detector de condutividade térmica e colunas PORAPAK-Q (de análise) e PORAPAK-T (de referência), ambas com 2 m de comprimento, 1/4" de diâmetro interno e 80-100 mesh, operados a 50 C. Hidrogênio foi utilizado como gás de arraste.

Alíquotas de $1 \mathrm{~mL}$ da atmosfera dos frascos foram retiradas como amostra, com o auxílio de uma seringa gas tight, com trava para gases. Os frascos não foram despressurizados, e os resultados estão expressos em mmol/L de gás acumulado no headspace. A velocidade máxima de produção de metano foi calculada por meio do ajuste de Bolztmann (sigmoidal) das concentrações de metano obtidas, e derivação da curva originada, utilizando-se o software Origin 6.0 .

\subsubsection{Determinação dos ácidos orgânicos e álcool}

As análises do ácido acético foram realizadas em cromatógrafo a gás HP6890, equipado com coluna HP INNOWAX (Cross Linked Polyethilene) com 300 x 0,25 mm e 0,25 $\mu \mathrm{m}$ de espessura do filme. O injetor operou a $250^{\circ} \mathrm{C}$, com taxa de split de 1:20 e o detector de ionização de chama (FID) a $300^{\circ} \mathrm{C}$. Foram utilizados os gases hidrogênio (gás de arraste) com fluxo de 30 $\mathrm{mL} / \mathrm{min}$, nitrogênio (gás auxiliar) com fluxo de $33 \mathrm{~mL} / \mathrm{min}$ e ar sintético com fluxo de 300 mL/min. Solução de ácido crotônico, em concentração de 700 mg/L foi utilizado como padrão interno (MORAES et al., 2000).

Amostras de $2 \mathrm{~mL}$ foram coletadas, sob condições de assepsia, centrifugadas a 10000 rpm, acondicionadas em tubos de ensaio com tampa rosqueável de teflon e mantidos no freezer até o momento da análise. As amostras foram preparadas seguindo a metodologia de extração de Moraes et al. (2000), descrita a seguir.

- Adicionar a $2 \mathrm{~mL}$ de amostra 1,0 g de $\mathrm{NaCl}$ (P.A.); $100 \mu \mathrm{L}$ de solução de ácido sulfúrico 1 M; 100 L de solução de ácido crotônico e 0,60 mL de éter etílico purificado (gelado);

- Agitar a amostra no agitador de tubos (vórtex) por 1 minuto;

- Centrifugar a amostra por 1 minuto;

- Armazenar a amostra no freezer até o momento da análise cromatográfica;

- Injetar $1 \mu \mathrm{L}$ da fase orgânica. 
As concentrações (mg/L) de ácido acético foram calculadas em relação aos padrões, de acordo com os fatores de resposta (área pico do ácido/área pico do padrão interno) dos picos obtidos nos cromatogramas, com limite de detecção de ácido acético de 5,13mg/L.

As análises do ácido lático foram realizadas por cromatografia líquida (HPLC), em cromatógrafo SHIMADZU, equipado com controlador SCL 10 A, três bombas LC 10 AD, forno CTO 10 A e detector DIODE ARRAY DETECTOR em comprimento de onda de $210 \mathrm{~nm}$. Como fase estacionária, foi utilizada coluna Aminex HPX-87H BIO-RAD de exclusão iônica, 300 x 7,8 $\mathrm{mm}$, em forno de $45^{\circ} \mathrm{C}$. O efluente usado na fase móvel foi solução de $\mathrm{H}_{2} \mathrm{SO}_{4} 5 \mathrm{mM}$, com fluxo de $0,500 \mathrm{~mL} / \mathrm{min}$. O volume de injeção foi de $100 \mu \mathrm{L}$. As amostras foram coletadas e armazenadas da mesma maneira descrita no item 4.9.2, e sua preparação também foi realizada seguindo a metodologia de extração de Moraes et al. (2000). Nessa metodologia as amostras foram filtradas em filtro Millipore de 0,22 $\mu \mathrm{m}$ antes de serem injetadas. Empregou-se curva de calibração do ácido lático com menor concentração igual a 18,75 mg/L.

O etanol foi determinado em cromatógrafo a gás HP 6890, coluna HP INNOWAX - 30 $\mathrm{mm} \times 0,25 \mathrm{~mm} \times 0,25 \mu \mathrm{m}$, forno a $70^{\circ} \mathrm{C}$ e detector de ionização de chama (FID) a $300^{\circ} \mathrm{C}$. As amostras foram coletadas e armazenadas nas mesmas condições descritas no item 4.9.2. Depois de descongeladas, foram colocadas em frascos de volumes idênticos, fechados com batoques de borracha de butila, lacrados e mantidos em banho de água em ebulição por 10 minutos. Retiraram-se $400 \mu \mathrm{L}$ do headspace para ser injetado no cromatógrafo. Isobutanol foi utilizado como padrão interno. Empregou-se curva de calibração com menor concentração igual a 30,9 $\mathrm{mg} / \mathrm{L}$.

\subsection{Microscopia óptica}

Exames microscópicos das amostras foram realizados empregando-se microscopia de contraste de fase e fluorescência em aparelho Leica DMLB, com sistema de câmera colorida digital Optronics. O software utilizado para aquisição das imagens foi o Image Pro-Plus versão 3.0.1. Por meio desse equipamento foi possível captar as imagens na tela de computador de 17 polegadas, e registrar as morfologias microbianas.

Para a realização dos exames microscópicos, as amostras foram retiradas com agulha hipodérmica esterilizada. Para a observação das amostras, ágar $2 \%$ foi aquecido em forno microondas por aproximadamente 1 minuto e distribuído sobre a lâmina de vidro. Após sua 
solidificação, alíquota de amostra foi colocada sobre a lâmina e recoberta por lamínula. Foram analisados de 20 a 30 campos microscópicos no mapeamento das morfologias observadas nas amostras dos reatores.

\subsection{Hibridação fluorescente in situ}

A técnica de hibridação fluorescente in situ (FISH) foi utilizada para contagem e caracterização das bactérias do grupo BRS e arquéias metanogênicas presentes nos reatores em batelada. Foram utilizadas sondas de oligonucleotídeos específicas ao RNAr 16S dos Domínios Bacteria (EUB338) e Archaea (ARC915) e para o grupo geral das BRS pertencentes à subdivisão Proteobacteria (SRB385). Todas as sondas foram marcadas com corante fluorescente rodamina na extremidade 5', conforme descritas na Tabela 4.5.

Foi utilizada também a sonda NON 338 como controle negativo para quantificar as porcentagens de hibridações não específicas.

As concentrações finais das sondas utilizadas estão apresentadas na Tabela 4.6.

Tabela 4.5. Sondas de oligonucleotídeos utilizadas na hibridação fluorescente in situ.

\begin{tabular}{|c|c|c|c|c|}
\hline Sonda & Especificidade & Seqüência $\left(5^{\prime} \rightarrow 3^{\prime}\right)^{*}$ & $\begin{array}{c}\text { Sítio do } \\
\text { RNAr } \\
16 S^{*}\end{array}$ & Referência \\
\hline NON338 & Controle negativo & ACTCCTACGGGAGGCAGC & $338-355$ & $\begin{array}{l}\text { Manz et al., } \\
1992\end{array}$ \\
\hline EUB338 & Domínio Bacteria & GCTGCCTCCCGTAGGAGT & $338-355$ & $\begin{array}{c}\text { Amann et al., } \\
1990\end{array}$ \\
\hline SBR385 & $\begin{array}{c}\text { Grupo geral de } \\
\text { BRS Gram } \\
\text { negativas da } \\
\text { subdivisão delta } \\
\text { de Protobacteria }\end{array}$ & CGGCGTCGCTGCGTCAGG & $385-402$ & $\begin{array}{c}\text { Amann et al., } \\
1990\end{array}$ \\
\hline ARC915 & Domínio Archaea & $\begin{array}{c}\text { GTGCTCCCCCGCCAATTC } \\
\text { CT }\end{array}$ & 915-934 & $\begin{array}{c}\text { Stahl e } \\
\text { Amann, } 1991\end{array}$ \\
\hline
\end{tabular}

* Posição do RNAr 16S de acordo com a numeração de Escherichia coli 
Tabela 4.6. Concentrações-estoque de cada sonda.

Sonda

Concentração Final Usada

na Hibridação $(\mathrm{ng} / \mu \mathrm{L})$

\begin{tabular}{ll}
\hline NON338 & 44,0 \\
EUB338 & 41,8 \\
SBR385 & 35,4 \\
ARC915 & 39,5 \\
\hline
\end{tabular}

Concentração obtida conforme descrito por Araújo (2001).

O FISH consistiu das seguintes etapas: desprendimento, lavagem e fixação das células planctônicas, preparação das lâminas de vidro, hibridação, microscopia de epifluorescência e contagem dos microrganismos. As etapas estão descritas a seguir.

\subsubsection{Preparação e fixação das amostras}

Para o desprendimento das amostras foram retirados dos reatores em batelada $4 \mathrm{~mL}$ de amostra, com seringa estéril, transferida para frascos de antibiótico estéril contendo 2 g de pérolas de vidro. Os frascos foram submetidos a atmosfera de $\mathrm{N}_{2}$ (100\%) durante 5 minutos. Depois de lacrados, os frascos foram agitados manualmente em ângulo de $45^{\circ}$ durante 20 minutos, e submetidos à homogeneização adicional por 5 minutos em agitador magnético. Em seguida, as amostras foram transferidas para frascos de $1 \mathrm{~mL}$ (em triplicata) para o procedimento de lavagem e fixação.

A lavagem das células foi realizada utilizando-se tampão fosfato salino (PBS 1X: 130 $\mathrm{mM} \mathrm{NaCl}+7 \mathrm{mM} \mathrm{Na} \mathrm{HPO}_{4}+3 \mathrm{mM} \mathrm{NaH}{ }_{2} \mathrm{PO}_{4}$ em $\mathrm{pH} 7,2$ ), por duas vezes, seguida de centrifugação por 1 minuto, com velocidade de $9000 \mathrm{rpm}$ a $15^{\circ} \mathrm{C}$. Após a lavagem, as células foram ressuspendidas em $200 \mu \mathrm{L}$ de PBS (1X) e $600 \mu \mathrm{L}$ de tampão de fixação com paraformaldeído $4 \%$ em PBS, e mantidas a $4^{\circ} \mathrm{C}$ por 12-16 horas. Terminado o período de fixação, as amostras foram lavadas duas vezes com PBS (1X), centrifugadas nas mesmas condições anteriores e ressuspendidas em PBS (1X)/etanol (1:1, v/v). As amostras foram armazenadas a $20^{\circ} \mathrm{C}$ até sua utilização. 
O tampão de fixação foi preparado pela dissolução de 2 g de paraformaldeído em 45 mL de água ultrapurificada, previamente aquecida a $60^{\circ} \mathrm{C}$. Foram adicionados, em seguida, $150 \mu \mathrm{L}$ de $\mathrm{NaOH} 1 \mathrm{~N}$ e $5 \mathrm{~mL}$ de PBS (1X). O pH da solução foi ajustado para 7,2 - 7,4, utilizando-se $\mathrm{HCl}$ (p.a.). O volume final foi completado até $50 \mathrm{~mL}$ com água ultrapurificada. A solução pode ser estocada em geladeira por no máximo 48 horas.

\subsubsection{Tratamento das lâminas de vidro}

Para a realização do FISH foram utilizadas lâminas de vidro revestidas com teflon (CelLine/Erie Scientific Co), com 12 pocinhos de 8 mm cada (Figura 4.3).

Antes da sua utilização, as lâminas foram submersas em solução de hidróxido de potássio 10\% em etanol durante 1 hora, lavadas em água corrente e destilada e mergulhadas em etanol para secagem. Em seguida, as lâminas foram imersas em solução de gelatina 0,2\% e $\mathrm{KCr}\left(\mathrm{SO}_{4}\right)_{2} \cdot 12 \mathrm{H}_{2} \mathrm{O}$ e secas à temperatura ambiente, na posição vertical, para se tornarem hidrófobas. Após o tratamento, as lâminas permaneceram estocadas sob refrigeração a $4{ }^{\circ} \mathrm{C}$ até sua utilização.

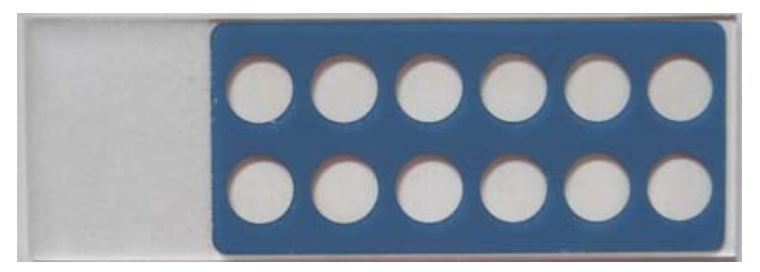

Figura 4.3. Lâmina de vidro revestida de teflon utilizada no FISH.

\subsubsection{Hibridação}

Para a realização da hibridação foi utilizado protocolo descrito por Araújo (2001). Alíquotas de $1 \mu \mathrm{L}$ de cada amostra foram espalhadas sobre os pocinhos das lâminas de vidro e levada para secar em forno de hibridação a $45^{\circ} \mathrm{C}$ durante 20 minutos, para promover a fixação das células na lâmina. Após esse período, as amostras foram desidratadas em séries gradativas de etanol 50\%, 80\% e 100\%, por 3 minutos em cada e secas em temperatura ambiente.

Após a desidratação em cada pocinho foram colocados $9 \mu \mathrm{L}$ de tampão de hibridação, previamente aquecido à temperatura de hibridação. Cerca de $1 \mu \mathrm{L}$ de sonda foi adicionada, para concentração final de 25-50 ng/ $\mu \mathrm{L}$. As composições dos tampões de hibridação e lavagem, e respectivas temperaturas de hibridação para cada sonda utilizada, seguem protocolo descrito na Tabela 4.7. 
A hibridação foi realizada no interior de frascos de polipropileno de $50 \mathrm{~mL}$ com tampa de rosca, contendo em seu interior papel filtro umedecido com tampão de hibridação pré-aquecido. Esses tubos foram revestidos externamente com papel alumínio e funcionaram como câmara úmida, para manter a concentração do tampão de hibridação inalterada e evitar a secagem das células. Os tubos foram levados ao forno de hibridação com tempos e temperatura adequados para cada sonda (Tabela 4.7).

Após a hibridação, as lâminas foram submersas em tubos de polipropileno (50mL) contendo o respectivo tampão de lavagem, por tempo e temperatura específicos para cada sonda (Tabela 4.7), em banho-maria. Em seguida, as lâminas foram levemente borrifadas com água ultrapurificada para a remoção de sais e sondas não-hibridadas e secas à temperatura ambiente. Depois de secas, foi adicionado em cada pocinho 10-20 $\mu \mathrm{L}$ de DAPI $10 \mu \mathrm{g} / \mathrm{mL}$ (4', 6-diamidino2-fenil indol, Sigma), por 10 minutos em temperatura ambiente e ausência de luz. Após esse período, as lâminas foram lavadas com água ultrapurificada para retirar o excesso de DAPI e colocadas para secar também em temperatura ambiente e ausência de luz.

Depois de secas, as lâminas foram cobertas com 1 a $2 \mu \mathrm{L}$ de glicerol/PBS (80/20, v/v), cobertas com lamínulas e observadas em microscópio de epifluorescência Olympus BX60-FLA. Esse tratamento foi utilizado para evitar o branqueamento das células devido à exposição prolongada à luz durante o exame microscópico. Foram utilizados filtros específicos, com excitação na região UV do espectro (para observação das células coradas com DAPI) e com excitação na região verde (para células coradas com rodamina). As imagens foram fotografadas com sistema de câmera acoplada para captura de imagem, em tempos de exposição de 0,08 s para contraste de fase e 0,5 s e 4,0 s para fluorescência.

Para a quantificação dos organismos, três imagens do mesmo campo microscópico foram fotografadas e arquivadas no computador: em contraste de fase, uma correspondente à excitação do DAPI (referente ao total de células) e outra correspondente à excitação da rodamina (referente às células hibridadas). As três imagens foram colocadas lado a lado para realização da contagem, e assim diferenciar células hibridadas de partículas abióticas, que às vezes apresentavam fluorescência com a sonda.

Para avaliação dos grupos microbianos presentes nas amostras, foi realizada a contagem do número total de células coradas com DAPI e contagem do número de células hibridadas com a sonda específica. Foram contadas de 800 a 1000 células de 30 a 40 campos aleatórios. A 
porcentagem de células hibridadas com sondas específicas, em cada campo microscópico, foi calculada em relação ao total de células coradas com DAPI.

Tabela 4.7. Protocolos de hibridação.

\begin{tabular}{|c|c|c|c|c|c|}
\hline Sondas & $\begin{array}{l}\text { Temperatura } \\
\text { e Tempo de } \\
\text { Hibridação }\end{array}$ & $\begin{array}{l}\text { Tampão de } \\
\text { Hibridação }\end{array}$ & $\begin{array}{c}\text { Temperatura } \\
\text { e Tempo de } \\
\text { Lavagem }\end{array}$ & $\begin{array}{l}\text { Tampão de } \\
\text { Lavagem }\end{array}$ & Referência \\
\hline EUB338 & $46^{\circ} \mathrm{C}$ & 0,9M NaCl, & $48^{\circ} \mathrm{C}$ & $20 \mathrm{mM}$ & ABE, 1998 \\
\hline NON338 & 1h30min & $\begin{array}{c}\text { 20mM TrisHCl, } \\
\text { 10mM EDTA, } \\
0,01 \% \text { SDS (pH } \\
\text { 7,2) + 20\% } \\
\text { formamida }\end{array}$ & 15 minutos & $\begin{array}{c}\text { TrisHCl, } \\
\text { 10mM EDTA, } \\
0,01 \% \text { SDS } \\
(\mathrm{pH} \mathrm{7,2)+} \\
225 \mathrm{mM} \mathrm{NaCl}\end{array}$ & \\
\hline SRB385 & $\begin{array}{c}45^{\circ} \mathrm{C} \\
2 \mathrm{~h}\end{array}$ & $\begin{array}{c}\text { 0,9M NaCl, } \\
\text { 20mM TrisHCl, } \\
\text { 10mM EDTA, } \\
0,01 \% \text { SDS (pH } \\
\text { 7,2) + 30\% } \\
\text { formamida }\end{array}$ & $\begin{array}{c}48^{\circ} \mathrm{C} \\
20 \text { minutos }\end{array}$ & $\begin{array}{c}\text { 20mM } \\
\text { TrisHCl, } \\
\text { 10mM EDTA, } \\
0,01 \% \text { SDS } \\
(\mathrm{pH} 7,2)+ \\
80 \mathrm{mM} \mathrm{NaCl}\end{array}$ & $\begin{array}{c}\text { HAHN et al., } \\
1992\end{array}$ \\
\hline ARC915 & $\begin{array}{c}45^{\circ} \mathrm{C} \\
2 \mathrm{~h}\end{array}$ & $\begin{array}{c}\text { 0,9M NaCl, } \\
\text { 20mM TrisHCl, } \\
\text { 10mM EDTA, } \\
0,01 \% \text { SDS (pH } \\
\text { 7,2) + 20\% } \\
\text { formamida }\end{array}$ & $\begin{array}{c}48^{\circ} \mathrm{C} \\
20 \text { minutos }\end{array}$ & $\begin{array}{c}\text { 20mM } \\
\text { TrisHCl, } \\
\text { 10mM EDTA, } \\
0,01 \% \text { SDS } \\
(\mathrm{pH} 7,2)+ \\
225 \mathrm{mM} \mathrm{NaCl}\end{array}$ & $\begin{array}{c}\text { HAHN et al., } \\
1992\end{array}$ \\
\hline
\end{tabular}




\section{RESULTADOS E DISCUSSÃO}

Os ensaios foram realizados em triplicata, entretanto, os resultados apresentados correspondem às médias aritméticas dos valores obtidos nos reatores com respostas mais semelhantes de cada condição, com respectivos desvios padrão.

\subsection{Reatores em batelada contendo acetato de sódio}

Nos reatores em batelada alimentados com acetato de sódio e adição de oxigênio foi verificada DQO inicial de $1463 \pm 11 \mathrm{mg} / \mathrm{L}$, potencial de oxi-redução de $382 \pm 23 \mathrm{mV}, 3,5 \mathrm{mg} / \mathrm{L}$ de OD, sólidos totais voláteis de 5135 mg/L e relação DQO/sulfato de 1,5 (Tabela 5.1). O ensaio, após 960 horas de operação, apresentou DQO de $207 \pm 27$ mg/L, resultando eficiência de 85,8\%. Após esse período, o potencial de oxi-redução foi de $-205 \pm 3 \mathrm{mV}$, OD igual a zero e sólidos totais voláteis de $3220 \pm 283 \mathrm{mg} / \mathrm{L}$. Ocorreu diminuição da quantidade de sólidos, o que indicou que houve redução da biomassa causada por morte celular, provavelmente, devido as novas condições nutricionais mais restritivas. O ácido acético adicionado $(757,7 \pm 85 \mathrm{mg} / \mathrm{L})$ foi totalmente consumido (Figura 5.1) em 120 horas de ensaio. Após esse período os valores encontrados estiveram abaixo do limite de detecção do método cromatográfico; ou seja, foram inferiores a 5,13 mg/L.

Nos reatores controle contendo acetato de sódio, a DQO inicial foi de $1291 \pm 14 \mathrm{mg} / \mathrm{L}$, potencial de oxi-redução de $98 \pm 2 \mathrm{mV}$, sólidos totais voláteis de $5135 \mathrm{mg} / \mathrm{L}$ e relação DQO/sulfato de 1,5 (Tabela 5.1). Este ensaio também teve duração de 960 horas, DQO final igual a $159 \pm 1 \mathrm{mg} / \mathrm{L}$, o que gerou eficiência de remoção de 87,7\%, e potencial de oxi-redução de -169 $\pm 2 \mathrm{mV}$.

Os sólidos totais voláteis também apresentaram diminuição da concentração, com valor de $3613 \pm 140 \mathrm{mg} / \mathrm{L}$. Como pode ser observado, a diferença entre os sólidos inicial e final dos ensaios controle foi pouco menor que nos ensaios com adição de oxigênio. No ensaio controle o ácido acético adicionado (874,5 $\pm 5 \mathrm{mg} / \mathrm{L})$ também foi totalmente consumido em 120 horas (Figura 5.1). Após esse período os valores encontrados estiveram abaixo do limite de detecção do método cromatográfico; ou seja, inferiores a 5,13 mg/L.

Nos reatores com oxigênio o potencial de oxi-redução no início foi mais positivo, comparando-se com os reatores controle, possivelmente devido a presença do oxigênio que deixou o meio oxidado. O valor do potencial redox nos reatores anaeróbios controle também 
apresentou valores positivos (potencial oxidado), devido à ausência de solução redutora e presença de sulfato de sódio, que é substância oxidada. No final dos ensaios, os reatores com oxigênio apresentaram potencial redox reduzido, devido a redução do oxigênio e formação de sulfeto. Nos reatores controle ao final do ensaio, o potencial redox encontrava-se reduzido, entretanto, menos reduzido que nos reatores com oxigênio.

Análises cromatográficas detectaram presença de ácidos propiônico, isobutírico, butírico e isovalérico em concentrações que variaram de 1,2 a 17,6 mg/L para os reatores controle e com oxigênio.

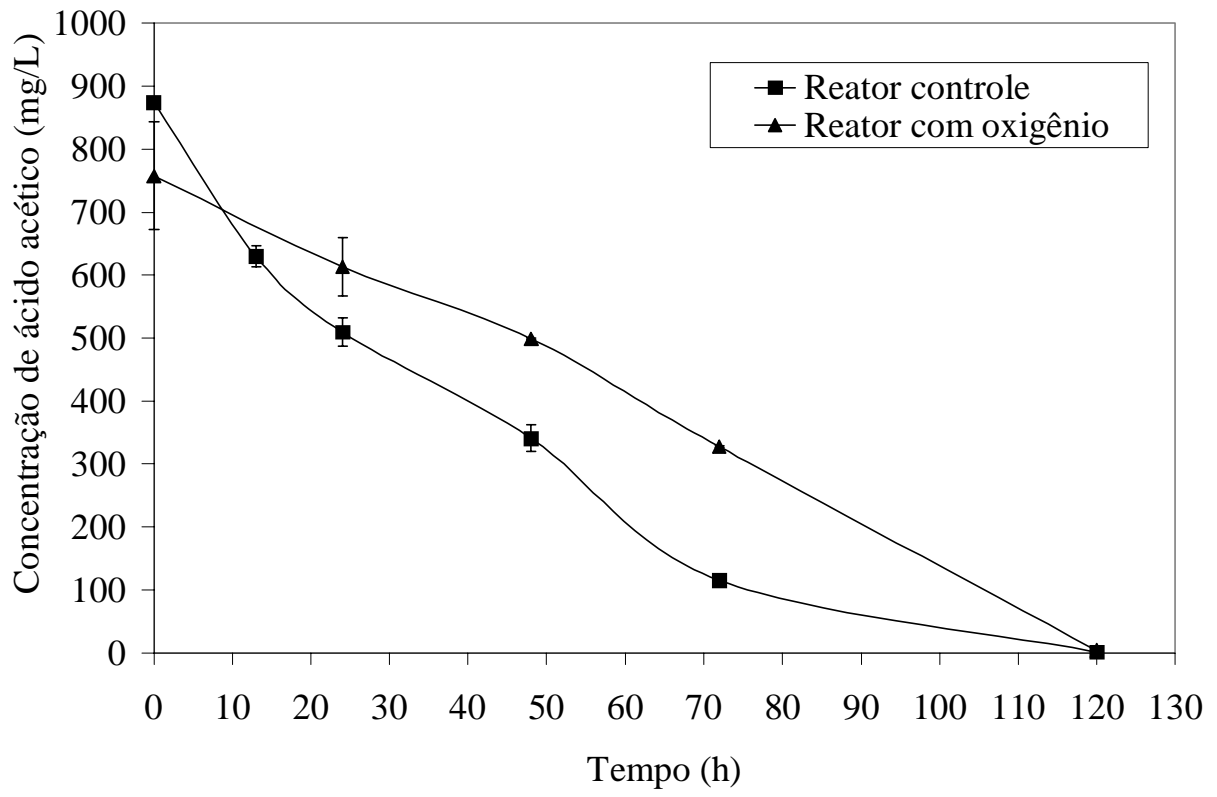

Figura 5.1. Variação temporal da concentração de ácido acético nos reatores em batelada.

Tabela 5.1. Relação DQO/sulfato, DQO inicial, potencial de oxi-redução, eficiência de remoção de DQO e sólidos totais voláteis dos reatores em batelada com acetato.

\begin{tabular}{|c|c|c|c|c|c|c|c|}
\hline \multirow{2}{*}{ Ensaio } & \multirow[t]{2}{*}{$\begin{array}{c}\text { Relação } \\
\text { DQO/Sulfato }\end{array}$} & & & & \\
\hline & & & \multicolumn{2}{|c|}{$\begin{array}{c}\text { Potencial de } \\
\text { Oxi-Redução } \\
\text { (mV) }\end{array}$} & & \multicolumn{2}{|c|}{$\begin{array}{c}\text { Sólidos Totais } \\
\text { Voláteis } \\
\text { (mg/L) } \\
\text { Inicial Final }\end{array}$} \\
\hline tato/Oxigênio & 1,5 & $\begin{array}{c}\text { DQO } \\
\text { inicial } \\
(\mathrm{mg} / \mathrm{L}) \\
1463\end{array}$ & 382 & -205 & $\begin{array}{c}\text { Eficiência } \\
\text { Remoção } \\
\text { DQO } \\
(\%) \\
050\end{array}$ & 5135 & 3220 \\
\hline ito/Controle & 1,5 & 1291 & 98 & -169 & 87,7 & 5135 & 3613 \\
\hline
\end{tabular}


Nos reatores alimentados com acetato e adição de oxigênio a produção de metano atingiu a velocidade máxima de 0,27 mmol/L.h em 55 horas, velocidade média de 0,037 \pm 0,07 mmol/L.h e concentração máxima de metano de 19 mmol/L (Tabela 5.2, Figura 5.2) em 132 horas de operação, estabilizando-se em seguida, no mesmo tempo de operação.

Nos reatores controle a velocidade máxima de produção de metano foi de $0,30 \mathrm{mmol} / \mathrm{L} . \mathrm{h}$ em 50 horas, velocidade média de 0,054 \pm 0,07 mmol/L.h e concentração máxima observada de 19 mmol/L (Tabela 5.2, Figura 5.2) em 137 horas de operação, estabilizando-se em seguida. As curvas de produção de metano tiveram valores de coeficiente de correlação $\left(R^{2}\right)$ iguais a 0,99 para ambos reatores, com oxigênio e controle.

Tabela 5.2. Velocidade máxima de produção de metano e concentração máxima de metano nos reatores alimentados com acetato de sódio.

\begin{tabular}{|c|c|c|c|}
\hline Ensaio & $\begin{array}{c}\text { Velocidade } \\
\text { Máxima de } \\
\text { Produção de } \\
\text { Metano } \\
\text { (mmol/L.h) }\end{array}$ & $\begin{array}{c}\text { Concentração } \\
\text { Máxima de Metano } \\
(\mathrm{mmol} / \mathrm{L})\end{array}$ & $\begin{array}{c}\text { Período da } \\
\text { Produção Máxima } \\
\text { de Metano } \\
\text { (h) }\end{array}$ \\
\hline Acetato/Oxigênio & 0,27 & 19 & 132 \\
\hline Acetato/Controle & 0,30 & 19 & 137 \\
\hline
\end{tabular}




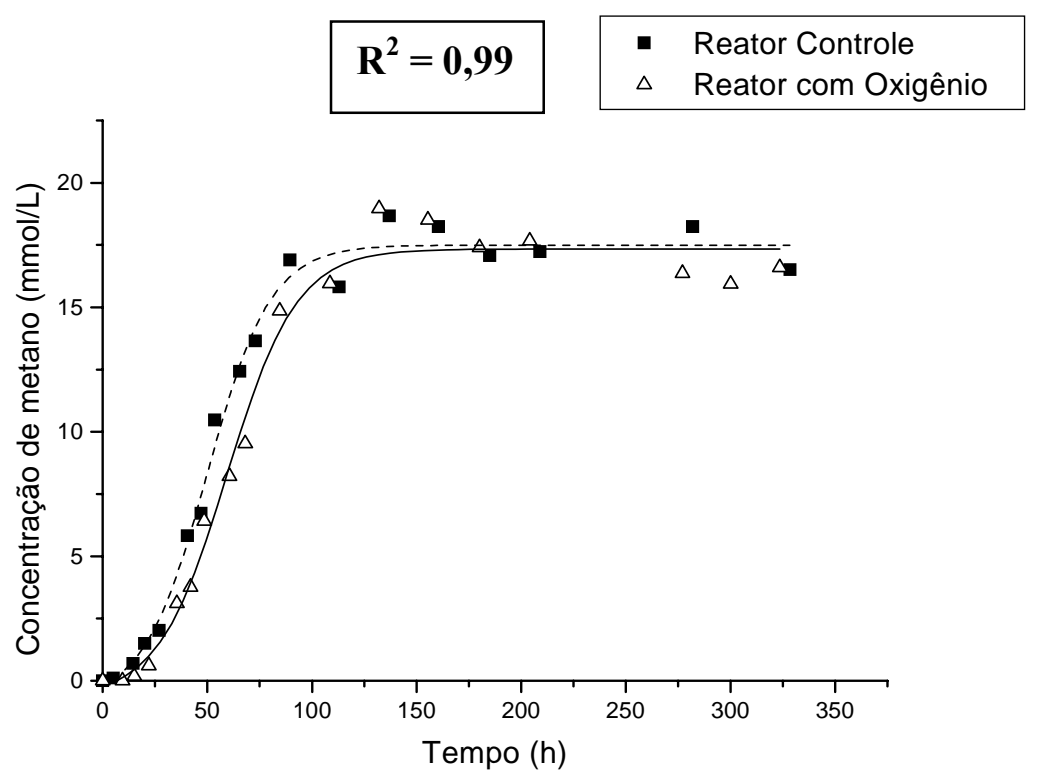

Figura 5.2. Variação temporal da concentração de metano nos reatores contendo acetato, com oxigênio e controle.

Pode-se observar que nos reatores com oxigênio a velocidade de produção de metano foi semelhante à velocidade observada nos reatores controle, além disso, a concentração de metano observada foi a mesma para os dois reatores (19 mmol/L). Portanto, a presença de oxigênio nos reatores contendo acetato de sódio não afetou a metanogênese.

Zitomer e Shrout (1998) estudaram a atividade metanogênica em reatores em batelada contendo sacarose, onde foram adicionadas quantidades de 4, 12 e $48 \mathrm{~mL}$ de oxigênio, a cada dois dias. Os autores também observaram valores de metano produzidos semelhantes (aproximadamente $20 \mathrm{~mL}$ ) nos reatores anaeróbios controle e em reatores que receberam $48 \mathrm{~mL}$ de oxigênio. Os autores atribuem tal desempenho à oxidação aeróbia de compostos intermediários (ácido propiônico, ácido acético e hidrogênio) por bactérias facultativas, que retiraram oxigênio do meio, favorecendo, assim, a metanogênese. Além disso, segundo os mesmos autores, as metanogênicas sobreviveriam devido à formação de micronichos anaeróbios.

Neste presente trabalho, o hidrogênio e outros compostos intermediários, provavelmente, foram utilizados por bactérias facultativas ou BRS, para reduzir o oxigênio do meio, e desse modo restabelecer condições anaeróbias para a metanogênese.

O consumo de sulfato nos reatores contendo acetato e adição de oxigênio foi de 97\%, para 
concentração inicial de $960 \pm 57 \mathrm{mg} / \mathrm{L}$, restando ao final do ensaio $30 \pm 14 \mathrm{mg} / \mathrm{L}$ de sulfato (Figura 5.3). A velocidade máxima de consumo do sulfato foi de $1,97 \mathrm{mg} / \mathrm{L}$.h, observada em $\mathrm{t}=0$ (apêndice A) e velocidade média de 0,89 \pm 0,5 mg/L.h. O sulfeto analisado no biogás, somente, começou a ser detectado com 541 horas de operação. Após 707 horas foi observada concentração máxima de $1 \mathrm{mmol} / \mathrm{L}$. Considerando a quantidade de sulfato adicionado, estequiometricamente sua redução produziria 9,7 mmol/L de sulfeto total (biogás e dissolvido), sendo 3,1 mmol/L referente ao sulfeto dissolvido, calculado teoricamente. Entretanto, o sulfeto total (biogás e dissolvido) observado nos ensaios foi 4,1 mmol/L, ou seja, valor inferior ao teórico.

Nos reatores controle contendo acetato, a concentração inicial de sulfato foi de $950 \pm 14$ $\mathrm{mg} / \mathrm{L}$ e final de $410 \pm 42 \mathrm{mg} / \mathrm{L}$ resultando consumo de 57\% (Figura 5.4). A velocidade máxima de consumo de sulfato foi de 1,01 mg/L.h, observada também em t=0 (apêndice B) e velocidade média de 0,52 \pm 0,2 mg/L.h. O sulfeto do biogás começou a ser detectado em 113 horas de operação. Após 664 horas foi observada concentração máxima de 1,5 mmol/L. A concentração teórica de sulfeto dissolvido foi calculada, obtendo-se o valor de 4,1 $\mathrm{mmol} / \mathrm{L}$. Estequiometricamente, a redução do sulfato adicionado produziria 5,6 mmol/L de sulfeto total (dissolvido e biogás), valor igual ao total de sulfeto observado nos ensaios (somando valores do sulfeto no biogás com o sulfeto dissolvido calculado).

A Tabela 5.3 mostra os valores de consumo de sulfato, tempo de início da detecção do sulfeto no biogás e concentrações máximas de sulfeto no biogás observadas nos reatores com oxigênio e controle, contendo acetato de sódio. A velocidade de consumo de sulfato nos reatores contendo oxigênio foi o dobro da verificada para os reatores controle, assim, a redução de sulfato pode ter sido favorecida na presença de oxigênio (Tabela 5.3). Canfield e Des Marais (1991) observaram maiores velocidades de redução de sulfato na superfície oxigenada $(1,8 \mu \mathrm{M} / \mathrm{min}$ a 2 mm de profundidade) em comparação com regiões mais profundas anaeróbias $(0,8 \mu \mathrm{M} / \mathrm{min}$ a 8 mm de profundidade) de biomassa contendo cianofíceas e bactérias de ambiente marinho. $\mathrm{O}$ mesmo comportamento pode ter ocorrido neste estudo; ou seja, maior velocidade de redução de sulfato nos reatores com oxigênio. 
Tabela 5.3. Consumo de sulfato, início do tempo de detecção de sulfeto no biogás e concentração máxima de sulfeto nos reatores contendo acetato de sódio.

\begin{tabular}{|c|c|c|c|c|c|}
\hline Ensaio & $\begin{array}{c}\text { Consumo } \\
\text { de Sulfato } \\
(\%)\end{array}$ & $\begin{array}{c}\text { Concentração } \\
\text { Inicial de } \\
\text { Sulfato } \\
(\mathrm{mg} / \mathrm{L})\end{array}$ & $\begin{array}{c}\text { Velocidade } \\
\text { Máxima } \\
\text { Consumo } \\
\text { sulfato } \\
\text { (mg/L.h) }\end{array}$ & $\begin{array}{c}\text { Início da } \\
\text { Detecção } \\
\text { do Sulfeto } \\
\text { (h) }\end{array}$ & $\begin{array}{c}\text { Concentração } \\
\text { Máxima } \\
\text { Sulfeto no } \\
\text { Biogás } \\
(\mathrm{mmol} / \mathrm{L})\end{array}$ \\
\hline Acetato/Oxigênio & 97 & 960 & 1,97 & 541 & 1 \\
\hline Acetato/Controle & 57 & 950 & 1,01 & 113 & 1,5 \\
\hline
\end{tabular}

Conforme pode ser observado na Figura 5.3 e Tabela 5.3, o sulfeto começou a ser detectado no biogás dos reatores com oxigênio, somente após 500 horas de ensaio. Isso pode ter ocorrido porque na presença de oxigênio as BRS podem primeiro ter realizado a redução dele, e somente quando o oxigênio foi esgotado do meio, iniciaram a redução de sulfato. Krekeler et al. (1998) observaram que ao adicionar oxigênio em células de BRS em suspensão, utilizando hidrogênio como doador de elétrons e sulfato ou tiossulfato como aceptores, a produção de sulfeto cessou e o oxigênio foi consumido.

Além disso, na presença de oxigênio, o sulfeto pode ser utilizado como doador de elétrons para a redução do oxigênio, e assim, o maior tempo para a detecção do sulfeto no biogás pode ter ocorrido porque o sulfeto teria sido oxidado na redução do oxigênio até este ser esgotado do meio. Comparando o período em que o sulfato começou a ser consumido e o período em que o sulfeto começou a ser detectado no biogás dos reatores com oxigênio (Figura 5.3), observa-se que quando o sulfeto começou a ser detectado o sulfato já havia começado a ser reduzido, o que mostra que o sulfeto produzido no começo dos ensaios, pode ter sido oxidado, na redução do oxigênio.

Para Dilling e Cypionka (1990) os compostos reduzidos de enxofre podem ser utilizados como substratos para a respiração aeróbia. Os autores observaram que Desulfovibrio desulfuricans oxidou completamente tiossulfato e sulfito com a adição de 2\% e 0,5\% de oxigênio no meio, respectivamente. Dannenberg et al. (1992) observaram a capacidade de oxidar sulfeto com oxigênio como aceptor de elétrons em cinco espécies de Desulfovibrio, em Desulfobulbus 
propionicus e Desulfococcus multivorans.

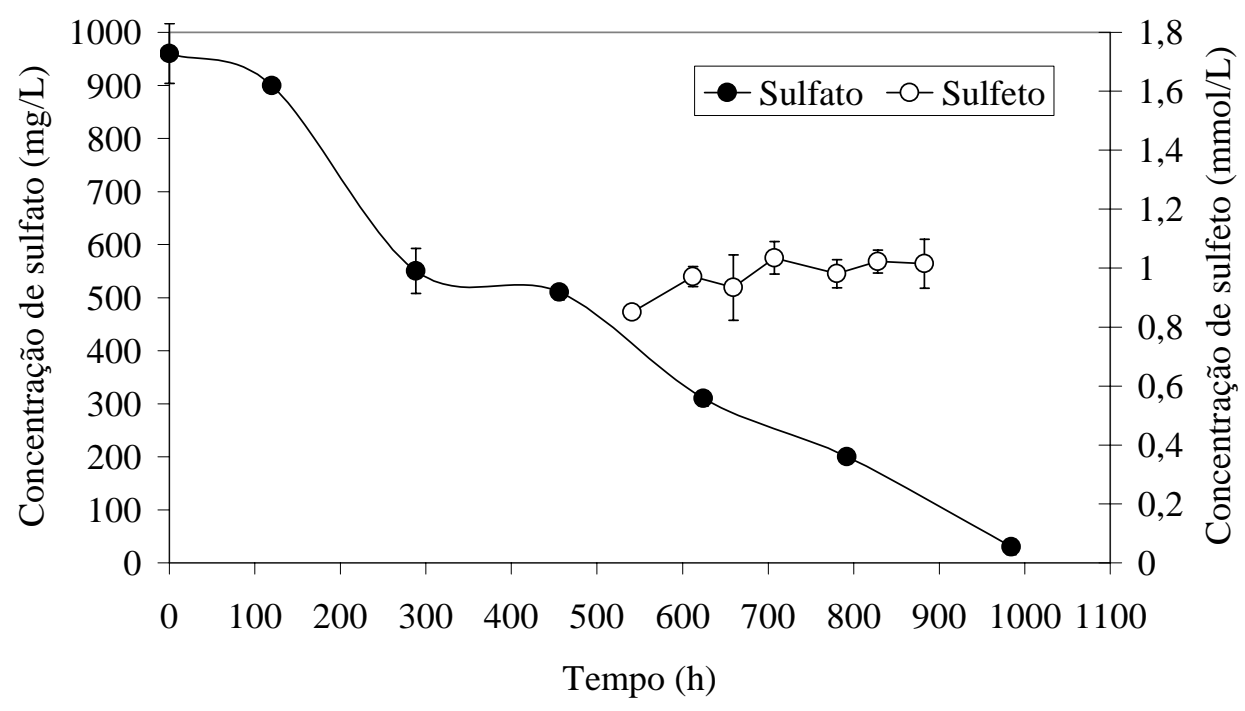

Figura 5.3. Variação temporal da concentração de sulfato e sulfeto nos reatores contendo acetato e oxigênio.

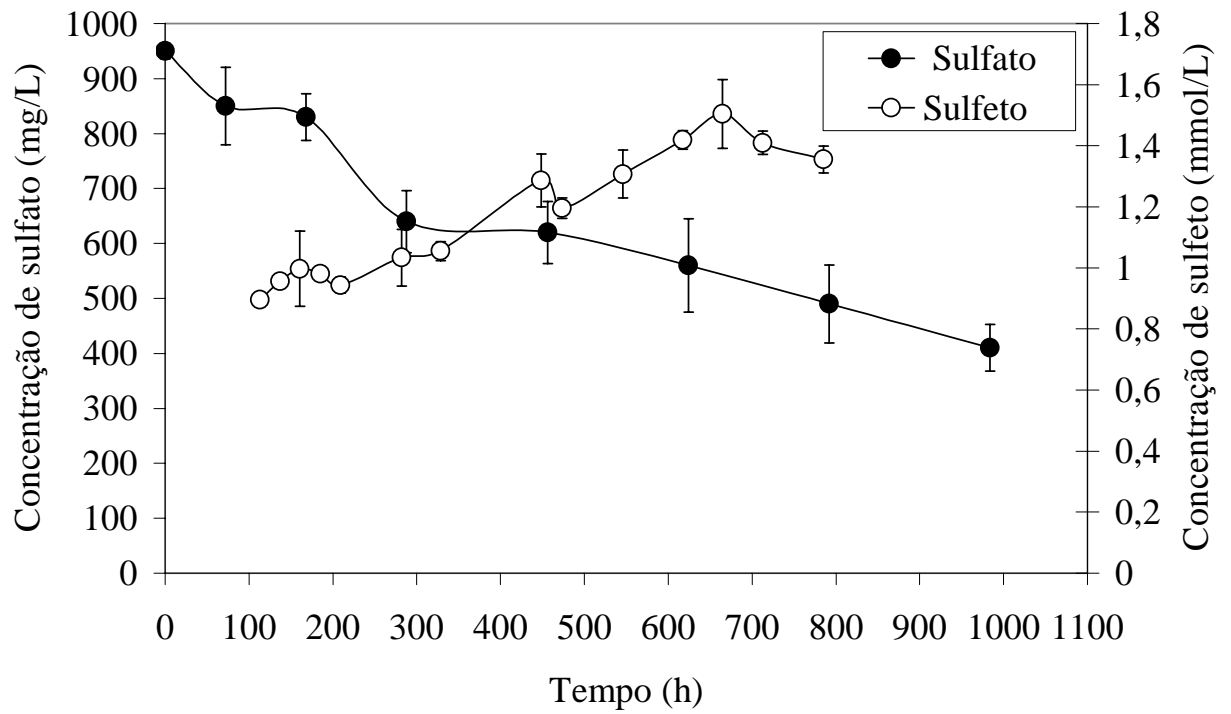

Figura 5.4. Variação temporal da concentração de sulfato e sulfeto no biogás dos reatores controle contendo acetato. 
A Figura 5.1 mostra que o consumo total do ácido acético ocorreu em 120 horas, tanto nos reatores com oxigênio, quanto nos reatores controle. Nesse período os valores foram abaixo do limite de detecção do método cromatográfico; ou seja, de 5,13 mg/L. Entretanto, a redução de sulfato durante esse período estava no início e continuou até o término do ensaio. Apesar do esgotamento da fonte orgânica adicionada, a redução de sulfato não cessou. Tal fato pode ser explicado pela presença de outras fontes orgânicas ou hidrogênio que foram utilizadas pelas BRS. Conforme citado anteriormente, houve diminuição da concentração de sólidos totais voláteis ao final do ensaio, o que mostra que ocorreu morte celular. Desse modo os organismos presentes podem ter utilizado os ácidos orgânicos e hidrogênio provenientes da degradação celular, para realizarem a redução do sulfato.

\subsubsection{Caracterização microbiana}

Por meio da observação sob microscopia óptica do lodo granulado utilizado como inóculo foi possível identificar as seguintes morfologias celulares: filamentos, cocos, bacilos com extremidades arredondadas, bacilos delgados, filamentos semelhantes a Methanosaeta sp. e morfologias semelhantes a Methanosarcina sp. (Tabela 5.4). Hirasawa (2003) usou o mesmo lodo granular proveniente de tratamento de água residuária de abatedouro de aves para avaliar a comunidade microbiana de reatores anaeróbios diferenciais e em batelada, sob condições sulfetogênicas e mesofílicas, e observou as mesmas morfologias. Entretanto, o autor encontrou bacilos fluorescentes e cistos de sarcinas, o que não foi verificado neste trabalho. A Figura 5.5 mostra algumas dessas morfologias observadas.

As porcentagens médias de microrganismos no inóculo detectadas pelas sondas EUB338, ARC915 e SRB385 foram, respectivamente, 49,8\% (erro padrão - EP: 3,3\%), 56,7\% (EP: 3,2\%) e 27,9\% (EP: 1,1\%) (Figura 5.5). Esses valores estão descritos na Tabela 5.5 e Figura 5.6. Esses resultados são compatíveis com os encontrados por Hirasawa (2003), que observou valores de 44,8\% (EP: 2,7\%) e 59,5\% (EP: 1,8\%) para as sondas EUB338 e ARC915, respectivamente. O autor não quantificou a porcentagem de BRS devido a problemas de homogeneização das amostras. Assim, com base nas porcentagens o lodo era predominantemente metanogênico. A Tabela 5.6 e Figura 5.7 mostram as morfologias hibridadas com as sondas EUB338, ARC915 e SRB385. 
As morfologias das células hibridadas com a sonda NON 338 foram anotadas para que fossem desconsideradas na contagem.

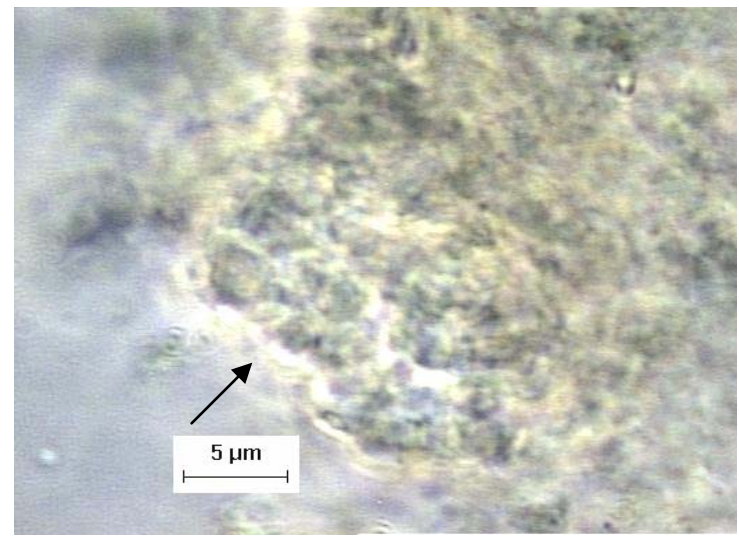

(a)

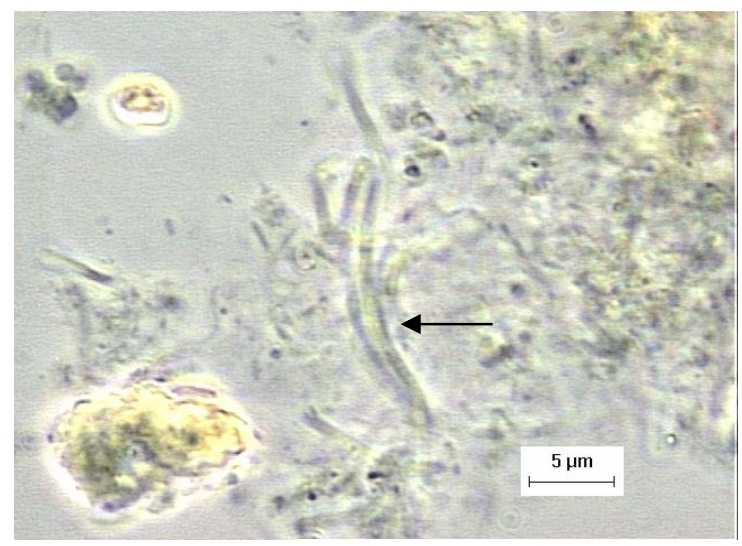

(c)

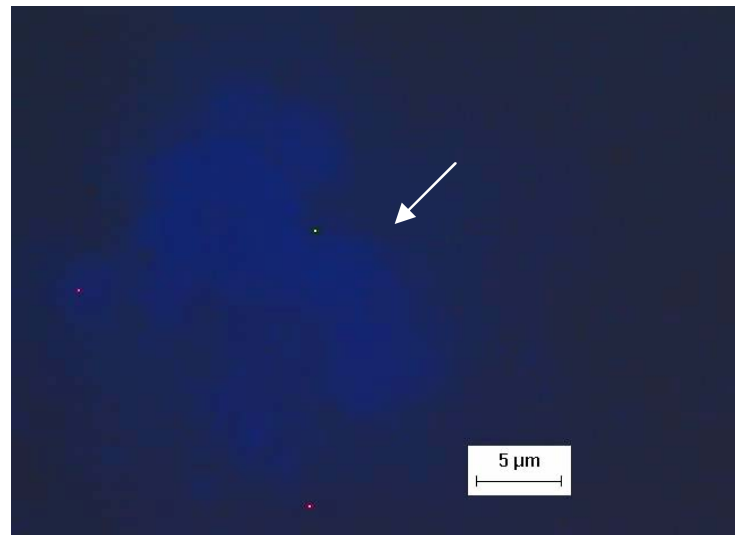

(b)

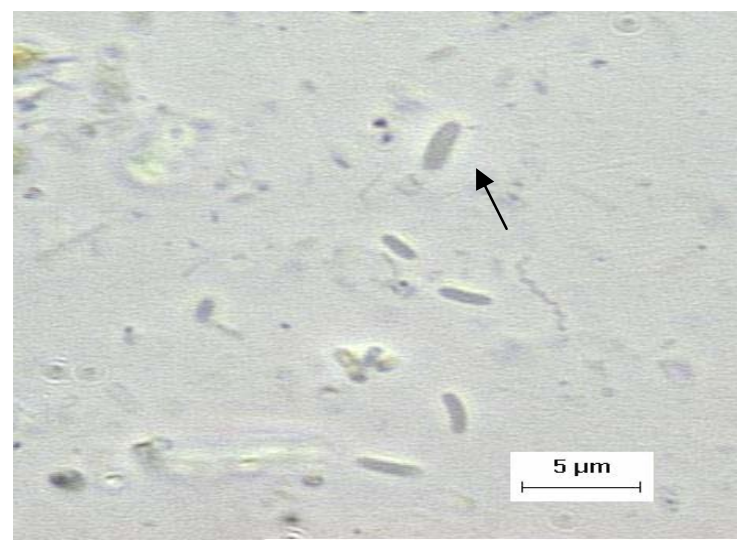

(d)

Figura 5.5. Morfologias observadas no inóculo sob microscopia óptica de contrate de fase e fluorescência: (a) morfologia semelhante a Methanosarcina sp., (b) fluorescência de Methanosarcina sp., (c) filamentos e (d) bacilos com extremidades arredondadas.

Segundo Raskin et al. (1994), a soma das porcentagens das células pertencentes aos Domínios Archaea, Bacteria e Eucarya, hibridadas com as sondas ARC915, EUB338 e EUK516, respectivamente, deve ser igual a 100\%. Entretanto, neste trabalho foram utilizadas apenas sondas ARC915 e EUB338, pelo fato de organismos eucariontes geralmente não estarem presentes nos sistemas de tratamento anaeróbio. Assim, a somatória das células hibridadas com as duas sondas deveria ser $100 \%$. No inóculo a somatória foi igual a 106,5\%, essa superestimativa 
da população total pode estar provavelmente relacionada com a intensidade do sinal fluorescente, preparação das amostras, desprendimentos dos arranjos celulares. Variações semelhantes também foram observadas por Domingues (2001) na avaliação da sulfetogênese e metanogênese utilizando substrato orgânico acetato, lactato e propionato, em reatores anaeróbios em batelada, sob condições termofílicas. Hirasawa (2003) também observou acréscimo na somatória das porcentagens do Domínio Bacteria e Archaea no estudo da comunidade microbiana em reatores sulfetogênicos com diferentes materiais suportes: espuma de poliuretano, carvão vegetal, polietileno e cerâmica porosa.

Tabela 5.4. Caracterização morfológica do inóculo.

\begin{tabular}{cc}
\hline Morfologia & Inóculo \\
\hline Arquéias metanogênicas & +++ \\
\hline Methanosarcina sp. & ++++ \\
\hline Methanosaeta sp. & - \\
\hline Cistos de sarcinas & +++ \\
\hline Bactérias & + \\
\hline Bacilos delgados com extremidades arredondadas & + \\
\hline Cocobacilos & + \\
\hline Cocos & + \\
\hline Espiroqueta & ++ \\
\hline Filamentos & - \\
\hline observados. &
\end{tabular}


Tabela 5.5. Porcentagens de microrganismos obtidos no inóculo por meio do FISH.

\begin{tabular}{lcccccc}
\hline Material & \multicolumn{2}{c}{ EUB338 } & \multicolumn{2}{c}{ ARC915 } & \multicolumn{2}{c}{ SRB385 } \\
& $\mathbf{( \% )}$ & $\begin{array}{c}\text { Erro } \\
\text { padrão }\end{array}$ & $\mathbf{( \% )}$ & $\begin{array}{c}\text { Erro } \\
\text { padrão }\end{array}$ & $\mathbf{( \% )}$ & $\begin{array}{c}\text { Erro } \\
\text { padrão }\end{array}$ \\
\hline Inóculo & 49,8 & 3,3 & 56,7 & 3,2 & 27,9 & 1,1 \\
\hline \hline
\end{tabular}

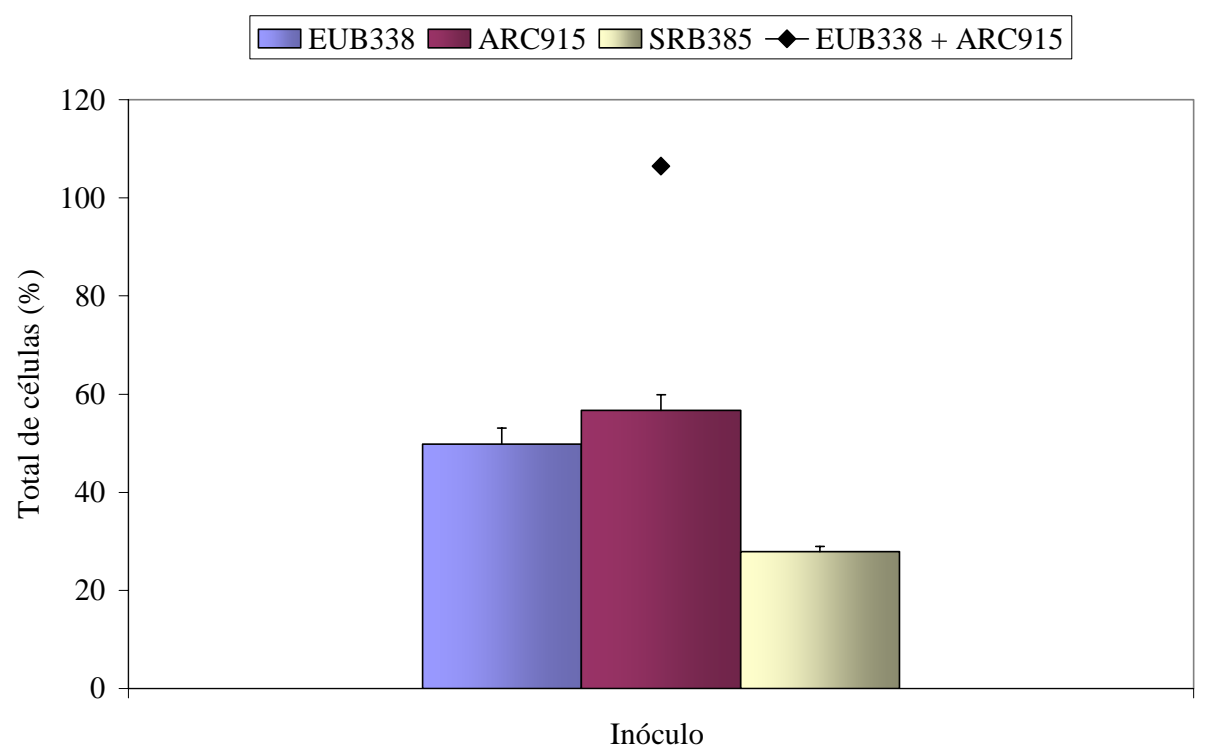

Figura 5.6. Composição da comunidade microbiana do inóculo. Abundância relativa de células pertencentes aos Domínios Bacteria (EUB338) e Archaea (ARC915) e BRS da subdivisão delta de Proteobacteria (SRB385) e soma dos dois Domínios (EUB338 + ARC915). As barras indicam o erro padrão.

Tabela 5.6. Morfologias das células predominantes no inóculo detectadas pelo FISH. Sonda Morfologia das Células Hibridadas

EUB338
Cocos, bacilos, cocobacilos

ARC915 Filamentos, sarcinas e bacilos SRB385 Cocos, bacilos, cocobacilos 


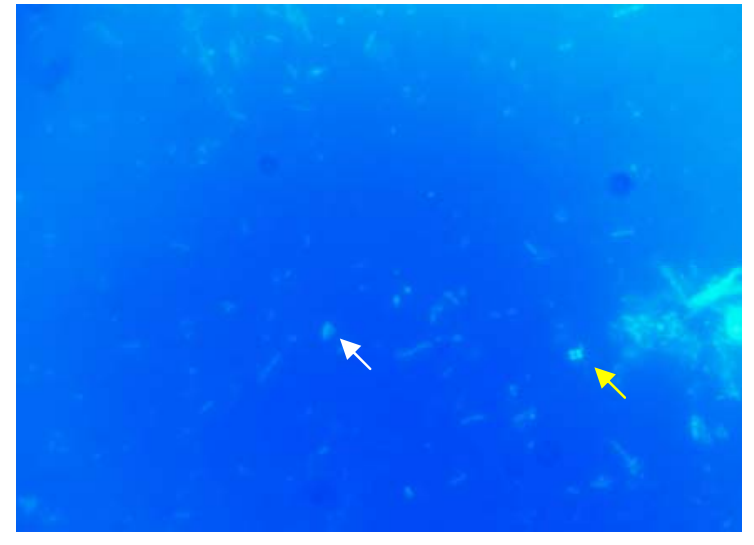

(a)

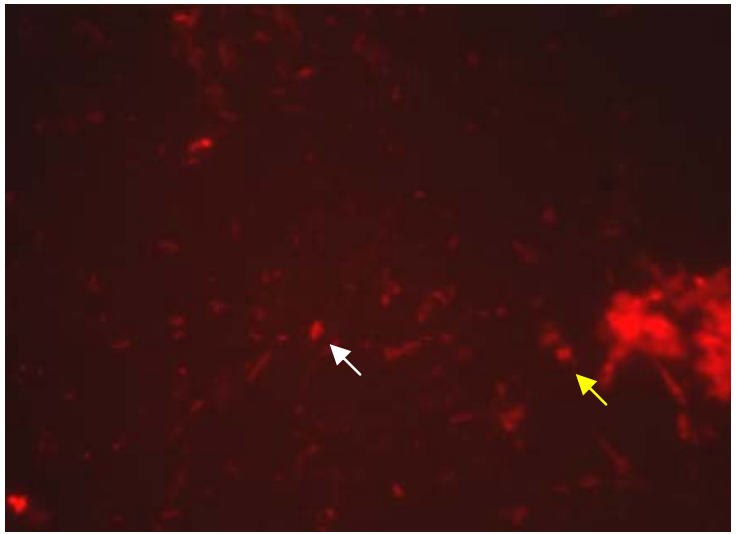

(b)

Figura 5.7. Morfologias hibridadas com a sonda EUB338: (a) células coradas com DAPI, (b) bacilo (seta branca) e cocos em forma de sarcina (seta amarela).

Nos reatores controle contendo acetato foram observadas as seguintes morfologias celulares: filamentos, cocos, bacilos com extremidades arredondadas, cocobacilos, bacilos delgados, morfologias semelhantes a Methanosaeta sp. e Methanosarcina sp. Nos reatores com oxigênio foram observadas as mesmas morfologias celulares. Em ambos reatores houve predominância de Methanosaeta sp. (Figura 5.8, Tabela 5.7). 
Tabela 5.7. Caracterização morfológica dos reatores contendo acetato.

\begin{tabular}{|c|c|c|}
\hline Morfologias & Reatores controle & Reatores com oxigênio \\
\hline \multicolumn{3}{|l|}{ Arquéias metanogênicas } \\
\hline Methanosarcina sp. & ++++ & +++ \\
\hline Methanosaeta sp. & ++++ & ++++ \\
\hline Cistos de sarcinas & - & + \\
\hline \multicolumn{3}{|l|}{ Bactérias } \\
\hline $\begin{array}{c}\text { Bacilos com extremidades } \\
\text { arredondadas }\end{array}$ & +++ & +++ \\
\hline Bacilos delgados & +++ & +++ \\
\hline Bacilos curvos & + & + \\
\hline Cocobacilos & +++ & ++++ \\
\hline Cocos & ++++ & ++ \\
\hline Espiroqueta & - & - \\
\hline Filamentos & - & - \\
\hline Filamentos segmentados & ++++ & +++ \\
\hline
\end{tabular}

Domingues (2001) avaliou a diversidade morfológica de reatores em batelada contendo acetato e sulfato sob condições termofílicas. O autor observou predomínio de sarcinas, bacilos fluorescentes, e bactérias com extremidades afiladas semelhantes a Desulfotomaculum sp. Outras morfologias também foram observadas; tais como bacilos com extremidades arredondadas, bacilos curvos, esporos de sarcinas e raros bacilos curvos. No presente trabalho, nos reatores com acetato não foi observada a presença de bacilos fluorescentes. Além disso, não foram observadas morfologias semelhantes a Desulfotomaculum sp. Tal fato justifica-se porque, embora sob condição anaeróbia com acetato como substrato orgânico, os inóculos e temperatura de incubação foram diferentes.

Amostras retiradas dos reatores em batelada, controle e com oxigênio, após 6 dias de operação e ao final do ensaio também foram hibridadas. Os resultados foram comparados entre si 
e com o inóculo. O período de 6 dias foi escolhido para comparação, devido à provável mudança na diversidade microbiana após esse período sob condições distintas.

Nos reatores controle com 6 dias de operação foram observadas as porcentagens de 40,5\% (EP: 1,9\%) para a sonda EUB338, 49,6\% (EP: 1,8\%) para ARC915 e 30,7\% (EP: 1,2\%) para SRB385. Nos reatores com oxigênio os valores observados foram de 40,4\% (EP: 2,1\%), 59\% (EP: 2,1\%) e 24,9\% (EP: 0,8\%), respectivamente (Figura 5.9).

Ao final dos ensaios foi observado nos reatores controle 37,6\% (EP: 2,2\%), 59,2\% (EP: 2,6\%) e 22\% (EP: 1\%) para as sondas EUB338, ARC915 e SRB385, respectivamente. Nos reatores com oxigênio foram observados 31,1\% (EP: 1,7\%), 60,7\% (EP: 2,4\%) e 17,3\% (EP: 1,1\%) respectivamente (Figura 5.9). As porcentagens de hibridação dos reatores alimentados com acetato estão descritas na Tabela 5.8. A Tabela 5.9 mostra as morfologias hibridadas pelas sondas EUB338, ARC915 e SRB385 nos reatores contendo acetato. 


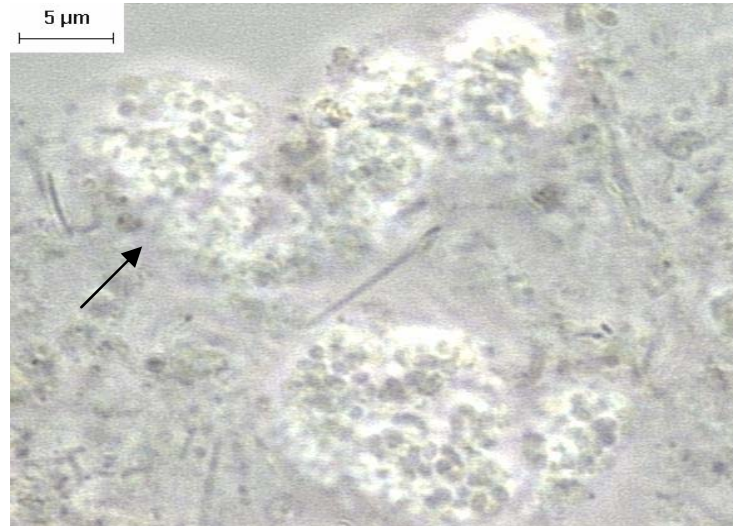

(a)

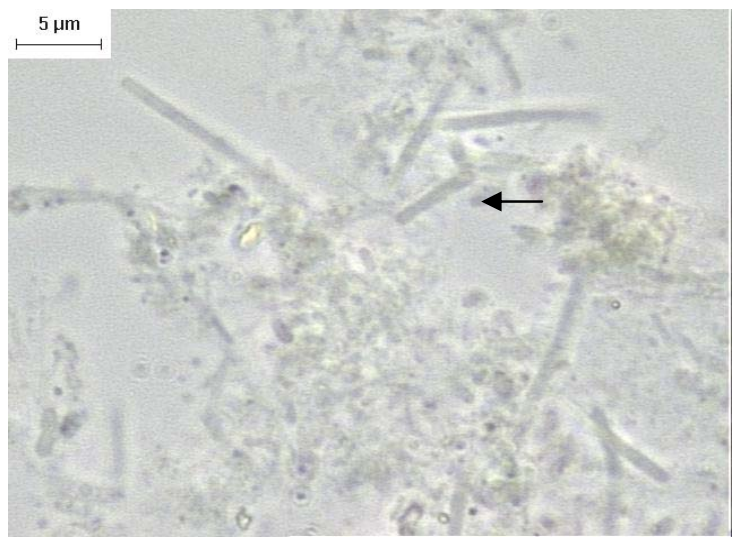

(c)

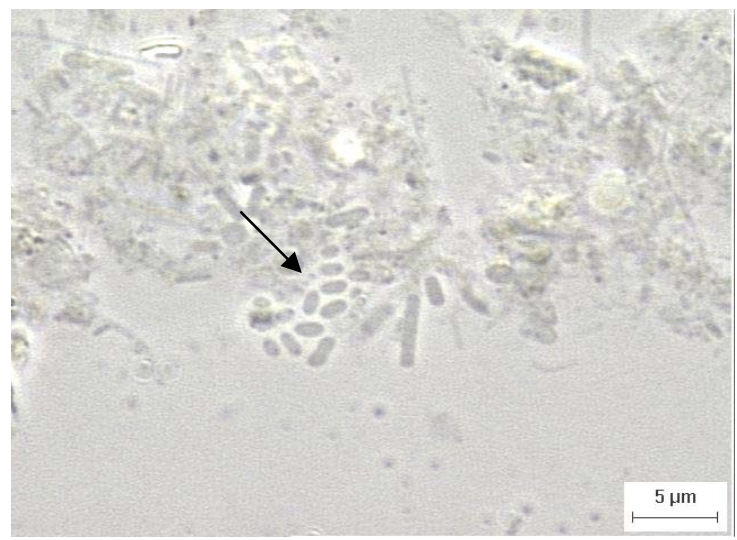

(e)

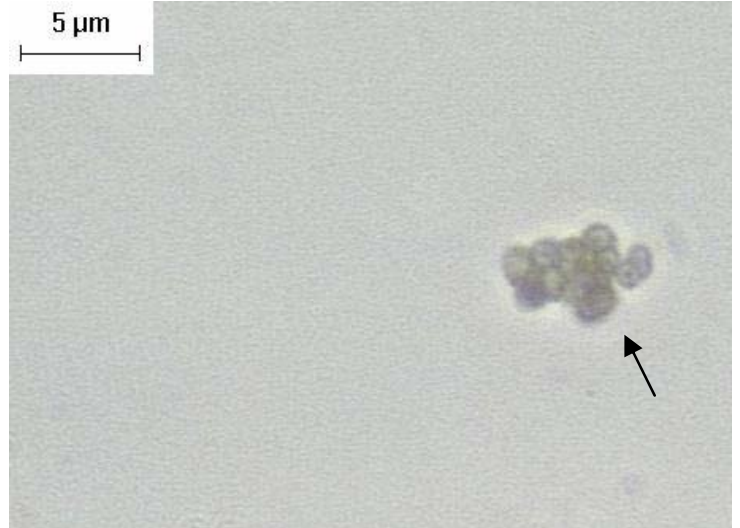

(b)

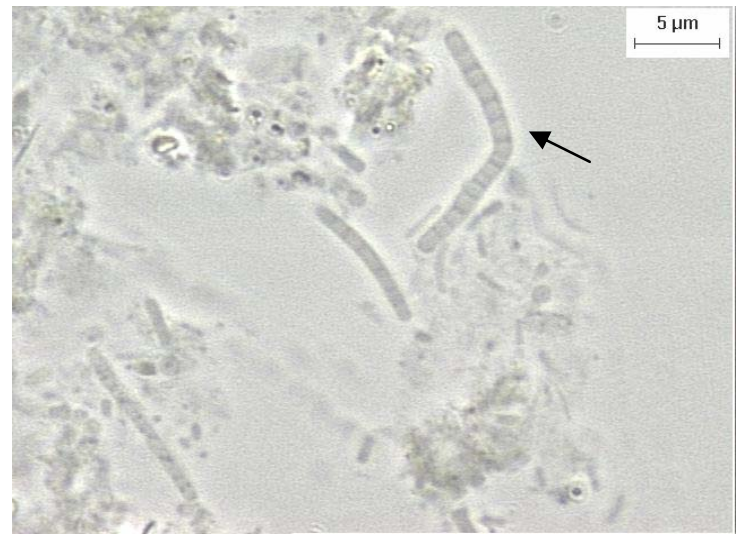

(d)

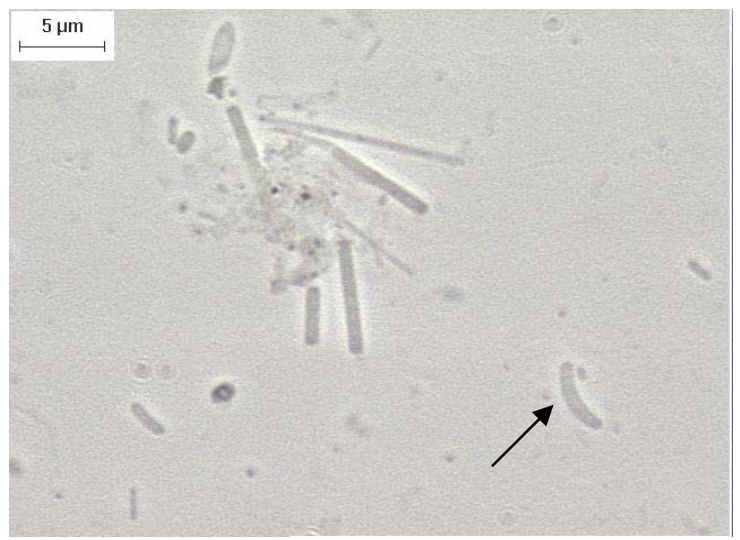

(f)

Figura 5.8. Morfologias observadas em microscopia óptica de contraste de fase nos reatores controle contendo acetato (a-c) e com adição de oxigênio (d-f): (a) morfologias semelhantes a Methanosarcina sp., (b) cocos, (c) morfologias semelhantes a Methanosaeta sp., (d) filamentos segmentados, (e) cocobacilos, (f) bacilo curvo. 


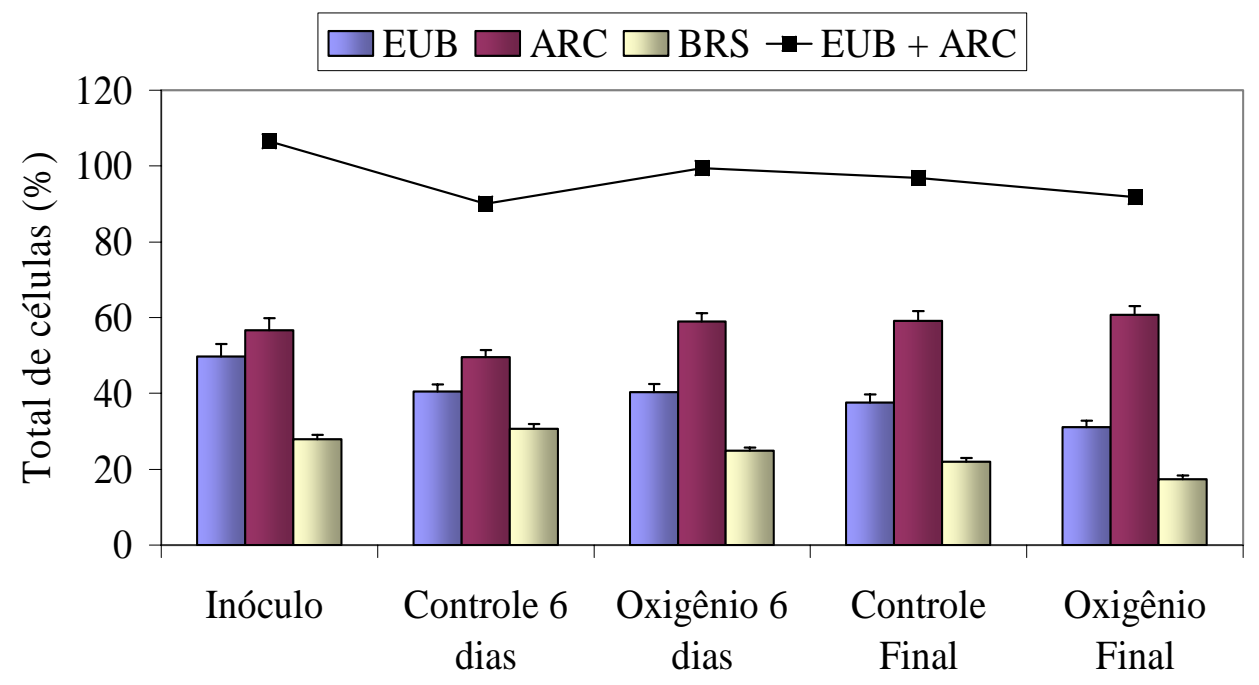

Figura 5.9. Comunidade microbiana nos reatores controle e com oxigênio contendo acetato. Abundância relativa de células pertencentes aos Domínios Bacteria (EUB338) e Archaea (ARC915) e grupo das BRS da subdivisão delta de Proteobacteria (SRB385) e soma dos dois Domínios (EUB338 + ARC915). As barras indicam o erro padrão.

Conforme pode ser observado na Figura 5.9, nos reatores contendo acetato houve predomínio de arquéias metanogênicas, tanto nos reatores controle quanto nos reatores com oxigênio. Esse resultado está em acordo com a produção de metano observada nos reatores (19 mmol/L). Nesses reatores a metanogênese não foi afetada pela presença do oxigênio.

A proporção de organismos do grupo das BRS diminuiu ao longo do ensaio nos reatores controle e com oxigênio, conforme pode ser observado na Figura 5.9. Apesar do elevado consumo de sulfato observado nos reatores com oxigênio (97\%), nesses reatores foi observada a menor proporção de BRS ao final do ensaio (17,3\%). Em contrapartida, nos reatores controle a proporção de BRS foi ligeiramente maior (22\%), embora a redução de sulfato menor (57\%). Tais resultados indicaram que na presença de acetato o crescimento das arquéias metanogênicas foi mais favorecido do que das BRS. O crescimento de BRS foi favorecido em condições anaeróbias, principalmente para aquelas que utilizam completamente o acetato. Outro aspecto importante refere-se à redução de sulfato, a qual foi maior nos reatores com oxigênio. Provavelmente, bactérias facultativas, não pertencentes ao grupo das BRS, usaram o substrato orgânico para reduzir sulfato. Todavia, estas não foram detectadas pela sonda SRB385 e também não apresentaram acréscimo nas porcentagens de EUB338, uma vez que as amostragens foram obtidas após 6 dias de operação. Provavelmente, em função da utilização de oxigênio, o aumento 
da biomassa seria observado no final de 2 dias de operação. Sendo assim, a biomassa coletada aos 6 dias, não apresentou RNAr em plena atividade e, conseqüentemente não foi possível a sua detecção. Mas, a sua presença foi constatada pela redução do sulfato.

Tabela 5.8. Porcentagens de microrganismos obtidos com o FISH nos reatores controle e com oxigênio contendo acetato.

\begin{tabular}{ccccccc}
\hline \hline Amostra & \multicolumn{2}{c}{ EUB338 } & \multicolumn{2}{c}{ ARC915 } & \multicolumn{2}{c}{ SRB385 } \\
& $(\%)$ & Erro & $(\%)$ & Erro & $(\%)$ & Erro \\
& & padrão & & padrão & & padrão \\
\hline Controle/6 dias & 40,5 & 1,9 & 49,6 & 1,8 & 30,7 & 1,2 \\
Controle/Final & 37,6 & 2,2 & 59,2 & 2,6 & 22 & 1 \\
Oxigênio/6 dias & 40,4 & 2,1 & 59 & 2,1 & 24,9 & 0,8 \\
Oxigênio/Final & 31,1 & 1,7 & 60,7 & 2,4 & 17,3 & 1,1 \\
\hline \hline
\end{tabular}

Tabela 5.9. Morfologias das células predominantes nos reatores contendo acetato, detectadas pelo FISH.

\begin{tabular}{|c|c|c|c|c|}
\hline \multirow[t]{2}{*}{ Sonda } & \multicolumn{4}{|c|}{ Morfologia das Células Hibridadas } \\
\hline & Controle/6 dias & Controle/Final & Oxigênio/6 dias & Oxigênio/Final \\
\hline EUB338 & $\begin{array}{c}\text { Cocos, } \\
\text { cocobacilos, } \\
\text { bacilos }\end{array}$ & $\begin{array}{c}\text { Cocos, } \\
\text { cocobacilos, } \\
\text { bacilos }\end{array}$ & $\begin{array}{l}\text { Cocos, bacilos, } \\
\text { cocobacilos, } \\
\text { filamentos, } \\
\text { bacilos curvos }\end{array}$ & $\begin{array}{l}\text { Cocos, bacilos, } \\
\text { bacilos curvos }\end{array}$ \\
\hline ARC915 & $\begin{array}{c}\text { Filamentos, } \\
\text { sarcinas, bacilos }\end{array}$ & $\begin{array}{c}\text { Filamentos, } \\
\text { sarcinas, bacilos }\end{array}$ & $\begin{array}{c}\text { Filamentos, } \\
\text { bacilos, sarcinas, } \\
\text { cocos }\end{array}$ & $\begin{array}{c}\text { Filamentos, } \\
\text { bacilos, sarcinas }\end{array}$ \\
\hline SRB385 & $\begin{array}{c}\text { Bacilos, cocos, } \\
\text { cocobacilos }\end{array}$ & $\begin{array}{c}\text { Cocos, } \\
\text { cocobacilos }\end{array}$ & $\begin{array}{c}\text { Cocos, } \\
\text { cocobacilos }\end{array}$ & $\begin{array}{c}\text { Cocos, bacilos, } \\
\text { cocobacilos }\end{array}$ \\
\hline
\end{tabular}

A somatória das células hibridadas com EUB338 + ARC915 foram, respectivamente, 90,1\% e 99,4\%, para os reatores controle e com adição de oxigênio, após 6 dias de operação; 
96,8\% e 91,8\%, para os reatores controle e com oxigênio, respectivamente, ao final do ensaio. Neste caso houve subestimativa da população total pelos mesmos motivos citados anteriormente.

Domingues (2001) realizou experimentos com reatores anaeróbios em batelada contendo acetato e sulfato, sob condições termofílicas. O autor também observou predomínio de arquéias metanogênicas (51,5\% - 67,6\%); ou seja, valores semelhantes aos observados nos reatores controle (anaeróbios) deste trabalho.

Omil et al. (1997) estudaram reator UASB em escala de bancada contendo acetato de sódio/sulfato de sódio e observou, por meio do FISH, que houve predomínio de Methanosaeta sp. após exposição ao ar durante 24 horas. Organismos do Domínio Archaea consistiram de 40 a 95\% do total de células no sistema. Apesar disso, os autores verificaram que a maior parte do acetato (cerca de 70\%) foi consumido pelas BRS, e não pelas arquéias metanogênicas.

De acordo com Yoda (1987), as BRS possuem maior afinidade ao acetato comparado com as arquéias metanogênicas, por possuírem menor valor de $\mathrm{k}_{\mathrm{s}}$. As BRS possuem $\mathrm{k}_{\mathrm{s}}$ igual a $102 \mathrm{mg}$ acetato/L, enquanto as arquéias metanogênicas têm $\mathrm{k}_{\mathrm{s}}$ igual a $116 \mathrm{mg}$ acetato/L. Segundo Lens et al. (1998), as BRS tendem a ter maiores velocidades de crescimento utilizando acetato, em comparação com as arquéias metanogênicas. Entretanto, a competição entre as BRS e arquéias metanogênicas depende de vários fatores, tais como, concentração de acetato, concentração de sulfato, pH, temperatura, entre outros (LENS et al., 1998). Especificamente, no presente trabalho, o inóculo foi predominantemente metanogênico confirmado por porcentagens de FISH e microscopia de fluorescência. Portanto, embora as BRS utilizem mais rapidamente o acetato, nas condições experimentais deste trabalho foi observado comportamento contrário. Provavelmente, as BRS que utilizam acetato estavam em menor número no inóculo (27,9\%, EP: 1,1\%) e foram desfavorecidas na presença do oxigênio (30,7\% a 22\%) e também em condições anaeróbias (24,9\% a 17,3\%), respectivamente no início (6 dias) e final (960 dias) dos experimentos.

\subsection{Reatores em batelada contendo etanol}

Nos reatores em batelada contendo etanol e adição de oxigênio a DQO inicial foi de 1128 $\pm 11 \mathrm{mg} / \mathrm{L}$, potencial de oxi-redução de $370 \pm 1 \mathrm{mV}, 4,4 \mathrm{mg} / \mathrm{L}$ de $\mathrm{OD}$, sólidos totais voláteis de 4507 mg/L e relação DQO/sulfato de 1,2 (Tabela 5.10).

Ao final do ensaio, com 816 horas, a DQO foi igual a $158 \pm 21 \mathrm{mg} / \mathrm{L}$, o que resultou em eficiência de $86 \%$ de remoção, potencial de oxi-redução de $-186 \pm 2 \mathrm{mV}$ e 0,41 mg/L de OD. A 
concentração de sólidos final também foi inferior a inicial, com valor de $2770 \pm 127 \mathrm{mg} / \mathrm{L}$. Foi observado consumo de 95,7\% do etanol após 72 horas de operação, para concentração inicial de 540,6 \pm 0,5 mg/L, resultando no final do ensaio $23 \pm 0,1 \mathrm{mg} / \mathrm{L}$ (Figura 5.10).

Os reatores controle alimentados com etanol apresentaram DQO inicial de $1016 \pm 13$ $\mathrm{mg} / \mathrm{L}$, potencial de oxi-redução inicial $-29 \pm 3 \mathrm{mV}$, sólidos totais voláteis de $5135 \mathrm{mg} / \mathrm{L}$ e relação DQO/sulfato de 1,1 (Tabela 5.10). Estes ensaios também tiveram duração de 816 horas, DQO final de $129 \pm 5 \mathrm{mg} / \mathrm{L}$, resultando em eficiência de remoção de 87,3\%, potencial de oxi-redução de $-168 \pm 7 \mathrm{mV}$ e sólidos totais voláteis final igual a $3453 \pm 254 \mathrm{mg} / \mathrm{L}$. Neste ensaio houve consumo de 90,3\% do etanol após 72 horas, para concentração inicial de 454,9 $\pm 1 \mathrm{mg} / \mathrm{L}$ e final de 19,9 \pm 0,3 mg/L (Figura 5.10).

Tabela 5.10. Relação DQO/sulfato, $D Q O$ inicial, potencial de oxi-redução, eficiência de remoção de DQO e sólidos totais voláteis dos reatores em batelada contendo etanol.

\begin{tabular}{cccccccc}
\hline \hline Ensaio & $\begin{array}{c}\text { Relação } \\
\text { DQO/Sulfato }\end{array}$ & $\begin{array}{c}\text { DQO } \\
\text { inicial }\end{array}$ & $\begin{array}{c}\text { Potencial de } \\
\text { Oxi-Redução }\end{array}$ & $\begin{array}{c}\text { Eficiência } \\
\text { Remoção }\end{array}$ & $\begin{array}{c}\text { Sólidos Totais } \\
\text { Voláteis }\end{array}$ \\
& & $(\mathbf{m g} / \mathbf{L})$ & $\begin{array}{c}(\mathbf{m V}) \\
\text { Inicial }\end{array}$ & Final & $\mathbf{( \% )}$ & \multicolumn{2}{c}{ (mg/L) } \\
& & & & Inicial & Final \\
\hline Etanol/Oxigênio & 1,2 & 1128 & 370 & -186 & 86 & 4507 & 2770 \\
Etanol/Controle & 1,1 & 1016 & -29 & -168 & 87,3 & 4507 & 3453 \\
\hline \hline
\end{tabular}

Nos reatores com etanol e oxigênio o potencial de oxi-redução foi positivo (oxidado), quando comparados com os reatores controle (reduzido). No final dos ensaios, os reatores com oxigênio apresentaram potencial redox reduzido, devido a redução do oxigênio e formação de sulfeto. Nos reatores controle também ao final do ensaio, o potencial redox encontrava-se reduzido, entretanto, menos reduzido que nos reatores com oxigênio, semelhante ao que ocorreu nos reatores com acetato. 


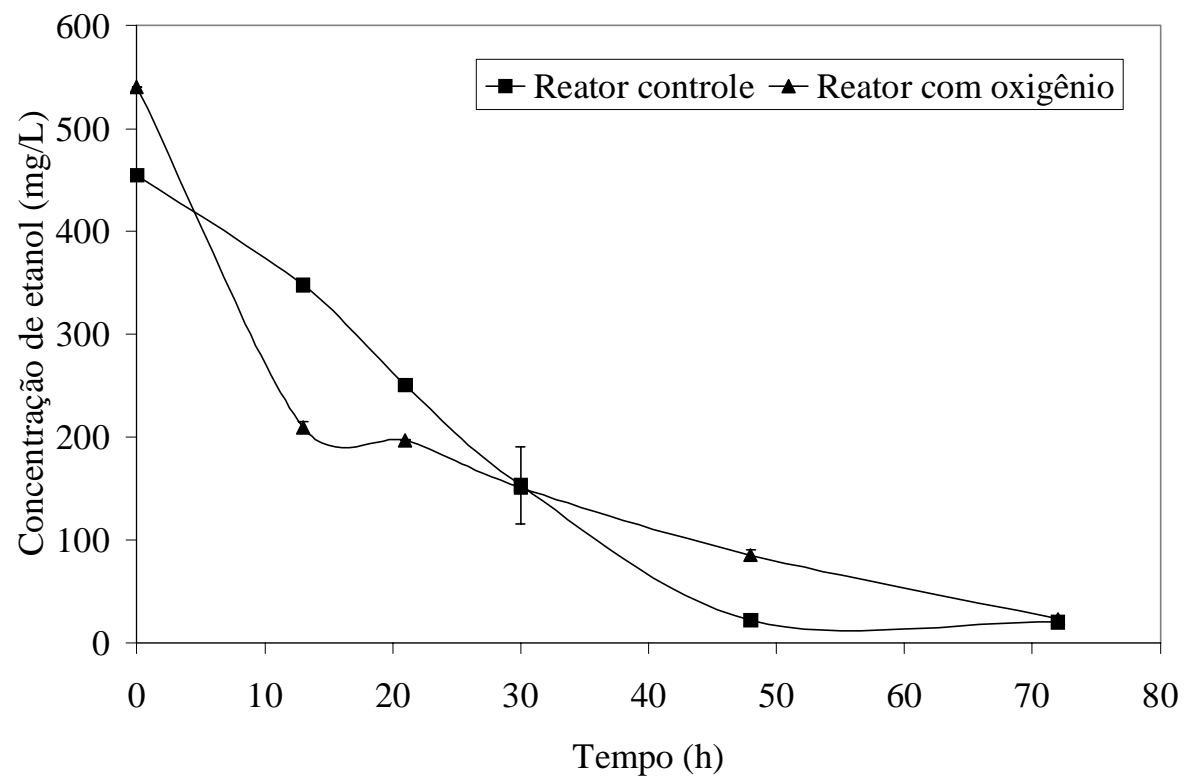

Figura 5.10. Variação temporal da concentração de etanol nos reatores em batelada.

Nos reatores alimentados com etanol e adição de oxigênio a velocidade máxima de produção de metano foi de 0,40 mmol/L.h em 25 horas, velocidade média de 0,024 \pm 0,07 mol/L.h e concentração máxima observada de 13 mmol/L (Tabela 5.11 e Figura 5.11) após 63,5 horas de operação, estabilizando-se também no mesmo tempo.

Nos reatores controle contendo etanol a velocidade máxima de produção de metano foi de 0,41 mmol/L.h em 24 horas, velocidade média de 0,038 \pm 0,09 mmol/L.h e concentração máxima de 14 mmol/L (Tabela 5.11 e Figura 5.11) em 63,5 horas, estabilizando-se em seguida. As curvas de produção de metano tiveram valores de coeficiente de correlação $\left(R^{2}\right)$ iguais a 0,99 para ambos reatores, com oxigênio e controle.

Nesses ensaios, as velocidades máximas de produção de metano foram maiores que as observadas nos reatores com acetato de sódio, embora as velocidades médias tenham sido inferiores. Entretanto, o etanol não é um substrato orgânico prontamente utilizado pelas arquéias metanogênicas. De acordo com Madigan et al. (1997), o etanol é fermentado em hidrogênio e acetato. Esta reação possui variação de energia livre positiva, portanto, desfavorável. O hidrogênio liberado da fermentação do etanol pode ter sido consumido pelas arquéias metanogênicas hidrogenotróficas e BRS, diminuindo, assim, a pressão parcial do hidrogênio e 
permitindo que a reação ocorresse no sentido de formação de acetato (MADIGAN et al., 1997).

Jones et al. (1984) estudaram a metanogênese a partir da sacarose utilizando consórcio microbiano composto por Escherichia coli, Acetobacterium woodii, Desulfovibrio vulgaris, Methanosarcina barkeri e Methanobacterium formicicum. Os autores observaram que E. coli fermentou a sacarose produzindo acetato, lactato, etanol, formiato, $\mathrm{CO}_{2}$ e $\mathrm{H}_{2}$. Segundo os mesmos autores, $D$. vulgaris (BRS) foi responsável pela oxidação do etanol a acetato, devido ao fato de que em culturas na ausência dessa bactéria, etanol foi detectado como produto ao final dos ensaios. O mesmo pode ter acontecido neste estudo, BRS ou bactérias acetogênicas oxidaram o etanol a acetato que foi utilizado pelas metanogênicas. Desse modo, tanto a metanogênese, quanto a redução de sulfato foram favorecidas.

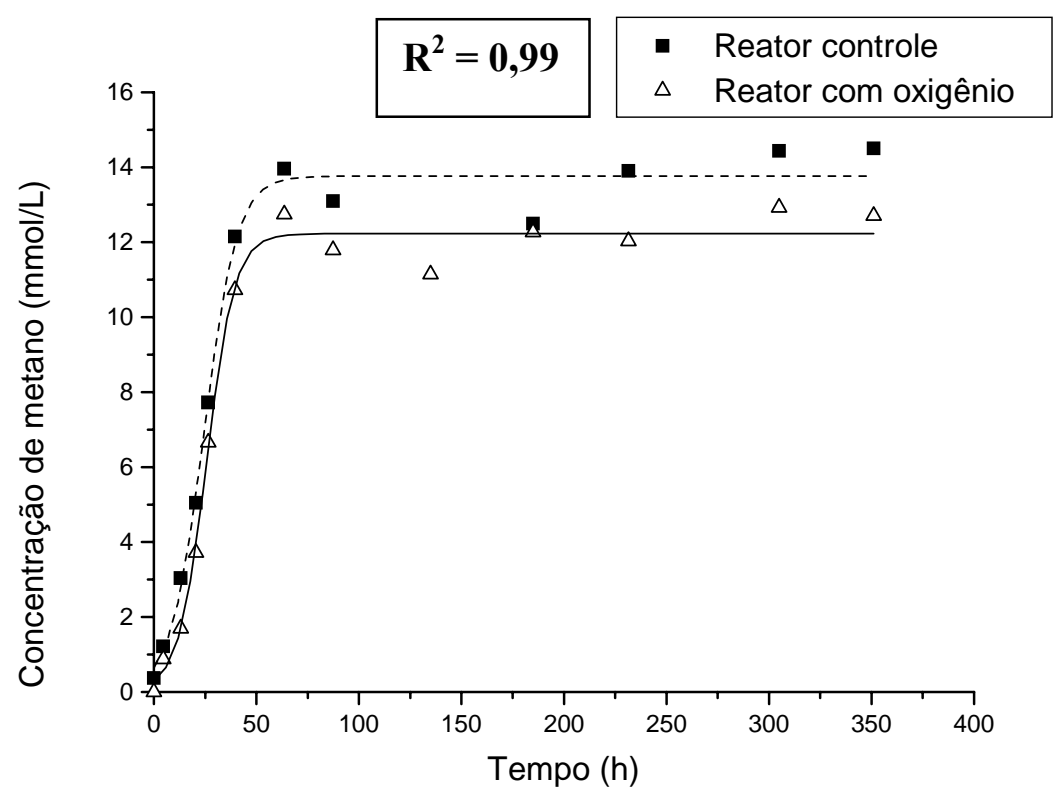

Figura 5.11. Variação temporal da concentração máxima de metano nos reatores contendo etanol com oxigênio e controle.

A concentração máxima de metano nos reatores com etanol e oxigênio e a velocidade máxima de produção do mesmo foram muito semelhantes aos valores observados nos reatores controle. Assim, pode-se supor que a concentração adicionada de oxigênio nos reatores contendo 
etanol não inviabilizou a metanogênese.

Tabela 5.11. Velocidade máxima de produção de metano e concentração máxima de metano nos reatores contendo etanol.

\begin{tabular}{|c|c|c|c|}
\hline Ensaio & $\begin{array}{c}\text { Velocidade } \\
\text { Máxima de } \\
\text { Produção de } \\
\text { Metano } \\
\text { (mmol/L.h) }\end{array}$ & $\begin{array}{c}\text { Concentração } \\
\text { Máxima de Metano } \\
(\mathrm{mmol} / \mathrm{L})\end{array}$ & $\begin{array}{c}\text { Período da } \\
\text { Produção Máxima } \\
\text { de Metano } \\
\text { (h) }\end{array}$ \\
\hline Etanol/Oxigênio & 0,40 & 13 & 63,5 \\
\hline Etanol/Controle & 0,41 & 14 & 63,5 \\
\hline
\end{tabular}

Nos reatores contendo etanol e oxigênio, a concentração inicial de sulfato foi 966,7 \pm 23 mg/L e final de 226,7 $\pm 50 \mathrm{mg} / \mathrm{L}$, resultando consumo de 76,6\% (Figura 5.12). A velocidade máxima de consumo de sulfato foi de 2,6 mg/L.h, observada no tempo inicial (tempo zero) (apêndice C) e velocidade média de 0,98 \pm 0,7 mg/L.h. O sulfeto no biogás começou a ser detectado após 39,5 horas de operação, atingindo valor máximo de 1,41 mmol/L em 495 horas. A concentração teórica de sulfeto dissolvido foi calculada, observando-se o valor de 4,3 mmol/L. Estequiometricamente, o sulfato adicionado produziria $7,7 \mathrm{mmol} / \mathrm{L}$ de sulfeto total (dissolvido e biogás), entretanto, nos reatores foi observado $5,71 \mathrm{mmol} / \mathrm{L}$ de sulfeto total, somando-se o valor do sulfeto no biogás com o sulfeto dissolvido calculado. Todavia, este valor foi inferior ao valor calculado estequiometricamente. Desse modo, nesses reatores com oxigênio, conforme observado também nos reatores com acetato, o sulfeto gerado pode ter sido oxidado na redução do oxigênio nas primeiras horas do ensaio.

Nos reatores controle contendo etanol, a concentração inicial de sulfato foi $906,7 \pm 12$ $\mathrm{mg} / \mathrm{L}$ e final de 366,7 $\pm 23 \mathrm{mg} / \mathrm{L}$, resultando consumo do sulfato de 59,6\% (Figura 5.13). A velocidade máxima de consumo de sulfato foi de 2,1 mg/L.h, também observada no início do ensaio ( $\mathrm{t}=0$ ) (apêndice $\mathrm{D}$ ) e velocidade média de 0,74 \pm 0,5 mg/L.h. O sulfeto presente no biogás começou a ser detectado após 20,5 horas de operação e observou-se concentração máxima de 1,46 mmol/L em 305 horas. A concentração teórica de sulfeto dissolvido também foi calculada, obtendo-se o valor de 4,3 mmol/L. Estequiometricamente, o sulfato adicionado produziria 5,6 $\mathrm{mmol} / \mathrm{L}$ de sulfeto total (biogás e dissolvido). De acordo com os valores observados no biogás e a 
concentração teórica calculada de sulfeto dissolvido, nesses reatores obteve-se 5,8 mmol/L de sulfeto total, valor muito semelhante ao teórico. Portanto, diferente do observado nos reatores com oxigênio, nesse caso pode-se supor que o sulfeto produzido não foi oxidado, uma vez que nesses reatores não havia oxigênio para ser reduzido.

A Tabela 5.12 mostra os valores de consumo de sulfato, tempo de início da detecção do sulfeto no biogás e concentrações máximas de sulfeto observadas nos reatores com oxigênio e controle contendo etanol. Conforme observado na mesma Tabela, nos reatores com etanol e oxigênio foi observada velocidade maior de consumo de sulfato, em comparação com os reatores controle.

Tabela 5.12. Consumo de sulfato, início do tempo de detecção de sulfeto no biogás e concentração máxima de sulfeto nos reatores contendo etanol.

\begin{tabular}{|c|c|c|c|c|c|}
\hline Ensaio & $\begin{array}{c}\text { Consumo } \\
\text { de Sulfato } \\
(\%)\end{array}$ & $\begin{array}{c}\text { Concentração } \\
\text { Inicial de } \\
\text { Sulfato } \\
\text { (mg/L) }\end{array}$ & $\begin{array}{c}\text { Velocidade } \\
\text { Máxima } \\
\text { Consumo } \\
\text { Sulfato } \\
\text { (mg/L.h) }\end{array}$ & $\begin{array}{c}\text { Início da } \\
\text { Detecção } \\
\text { do Sulfeto } \\
\text { (h) }\end{array}$ & $\begin{array}{c}\text { Concentração } \\
\text { Máxima de } \\
\text { Sulfeto no } \\
\text { Biogás } \\
(\mathrm{mmol} / \mathrm{L})\end{array}$ \\
\hline Etanol/Oxigênio & 76,6 & 966,7 & 2,6 & 39,5 & 1,41 \\
\hline Etanol/Controle & 59,6 & 906,7 & 2,1 & 20,5 & 1,46 \\
\hline
\end{tabular}

Conforme observado na Figura 5.10, o consumo total de etanol ocorreu em 72 horas, tanto nos reatores controle, quanto nos reatores com oxigênio. Da mesma maneira como observado nos reatores com acetato, mesmo após o consumo do substrato orgânico, a redução do sulfato não cessou. Nesse caso também foi observada redução na concentração de sólidos totais voláteis no final do ensaio, indicando morte celular. Assim, as BRS podem ter utilizado outros doadores de elétrons na redução do sulfato, como os ácidos orgânicos e hidrogênio. Entretanto, as maiores velocidades de consumo de sulfato foram observadas nas primeiras horas de operação dos reatores, provavelmente devidas ainda à presença de etanol, e quando este foi esgotado, foram utilizados os ácidos liberados pela morte celular. 


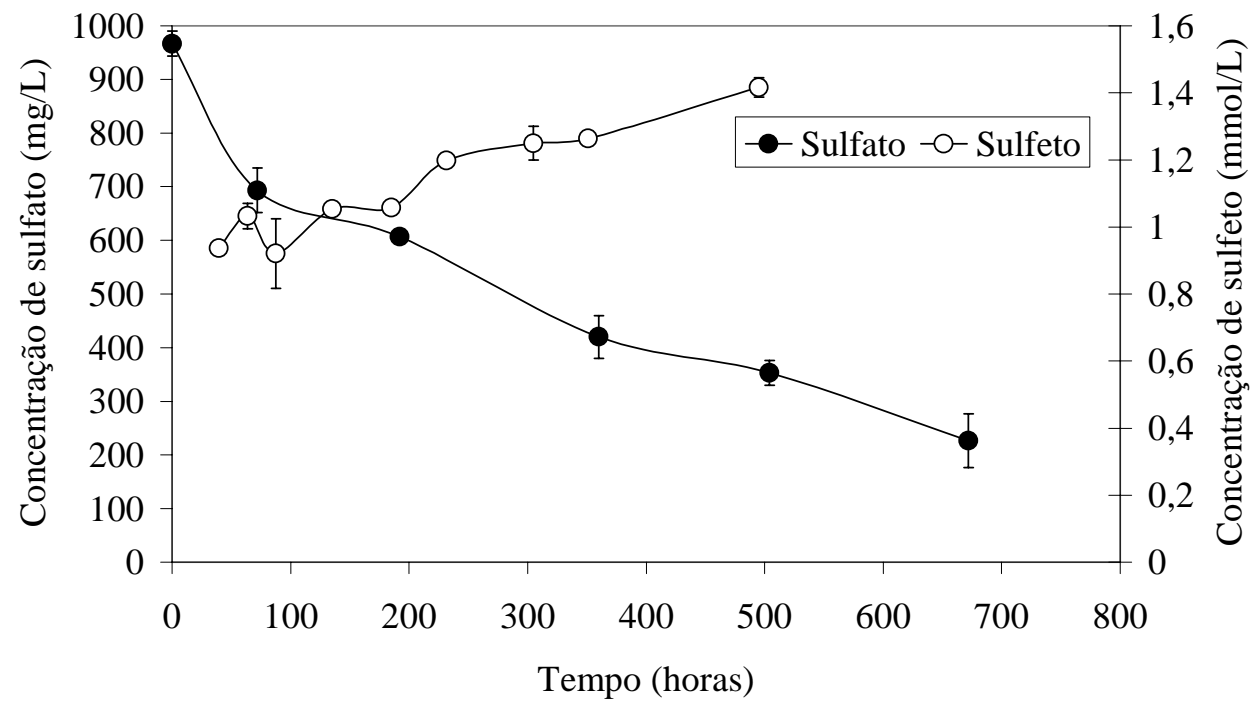

Figura 5.12. Variação temporal da concentração de sulfato e sulfeto no biogás dos reatores contendo etanol e oxigênio.

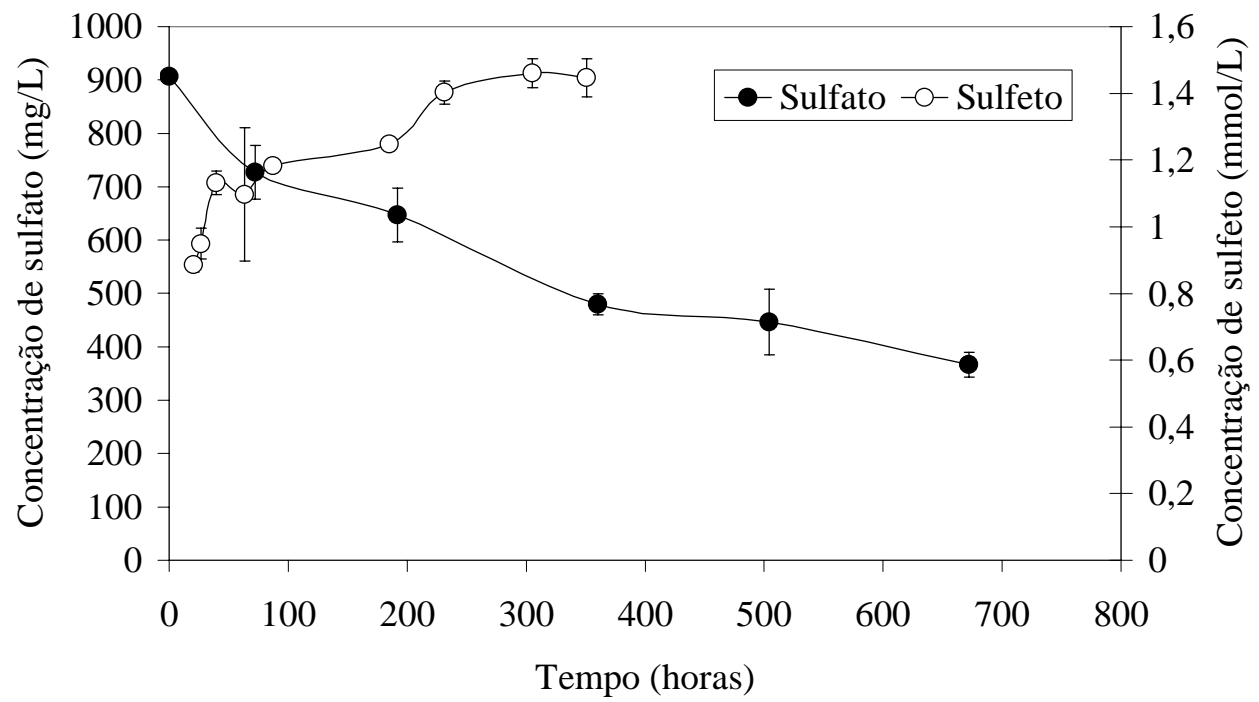

Figura 5.13. Variação temporal da concentração de sulfato e sulfeto no biogás dos reatores controle contendo etanol. 


\subsubsection{Caracterização microbiana}

As análises de microscopia mostraram as seguintes morfologias nos reatores controle com etanol: filamentos segmentados, cocos, cocobacilos, bacilos com extremidade arredondada, bacilos curvos, filamentos, morfologias semelhantes a Methanosarcina sp. e Methanosaeta sp. Nos reatores com oxigênio foram observadas as mesmas morfologias, entretanto bacilos curvos foram mais freqüentes. A predominância de Methanosaeta sp. foi observada em ambos os reatores. As arquéias pertencentes ao gênero Methanosarcina sp. são organismos diversos metabolicamente e podem utilizar outros substratos além do acetato (GARCIA et al., 2000). Todavia, possuem menor afinidade a esse substrato orgânico $\left(\mathrm{k}_{\mathrm{s}}=4,02 \mathrm{mM}\right)$ (DÍAZ et al., 2003). Por outro lado, arquéias semelhantes a Methanosaeta sp. utilizam apenas acetato como substrato para a metanogênese, e possuem maior afinidade a este substrato $\left(\mathrm{k}_{\mathrm{s}}=0,44 \mathrm{mM}\right)$ (DÍAZ et al., 2003). Entretanto, nesses reatores com etanol foi observado predomínio de arquéias semelhantes a Methanosaeta sp. Provavelmente, BRS ou bactérias acetogênicas oxidaram etanol em acetato, e este foi utilizado por Methanosaeta sp. A Tabela 5.13 mostra as freqüências desses organismos observadas nos reatores, e a Figura 5.14 mostras algumas dessas morfologias observadas.

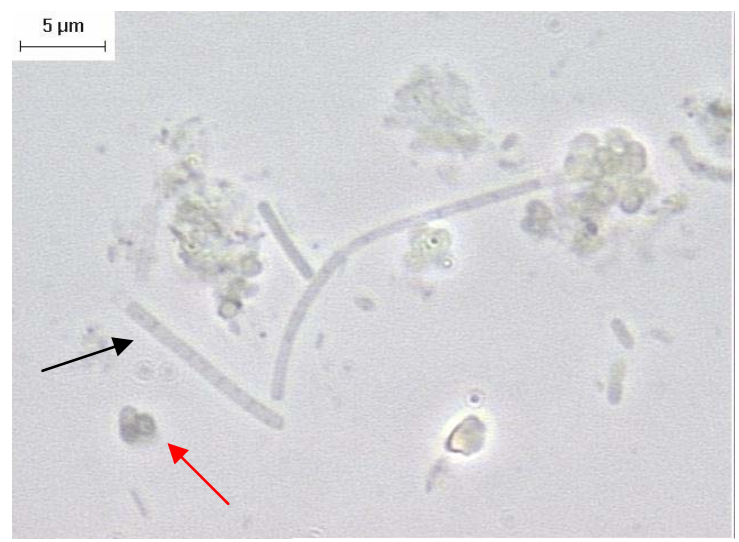

(a)

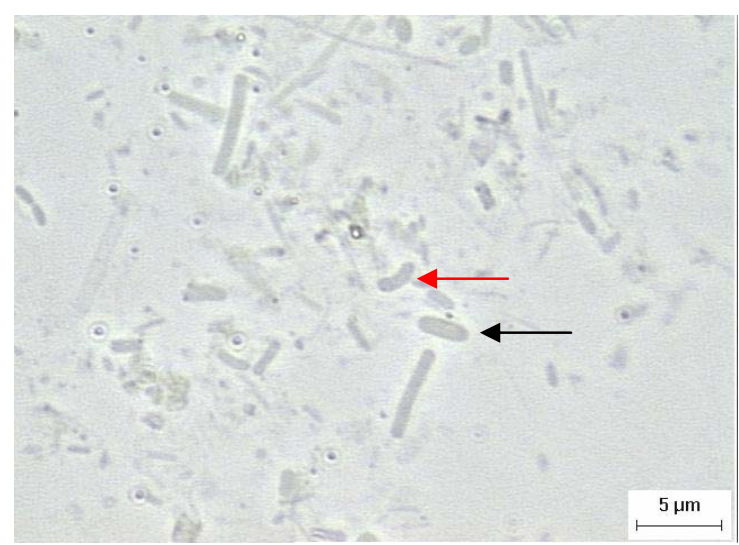

(b) 


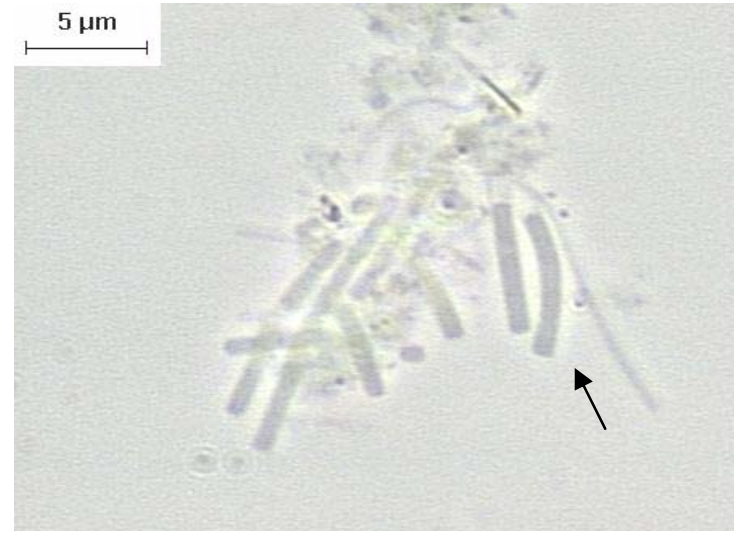

(c)

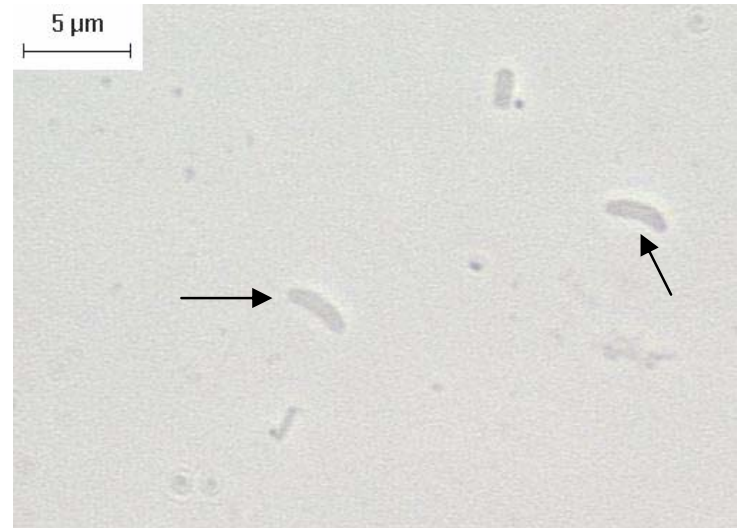

(d)

Figura 5.14. Morfologias observadas sob microscopia óptica de contraste de fase nos reatores alimentados com etanol controle (a-b) e com oxigênio (c-d): (a) cocos e filamentos segmentados, (b) bacilo com extremidade arredondada e bacilo curvo, (c) Methanosaeta sp., (d) bacilos curvos.

Amostras dos reatores controle e com oxigênio foram retiradas também após 6 dias de operação e ao final do ensaio para hibridação.

Nos reatores controle após 6 dias de operação foram observadas 41,2\% (EP: 2,3\%), 58,6\% (EP: 1,7\%) e 23,9\% (EP: 0,8\%) para as sondas EUB338, ARC915 e SRB385, respectivamente (Figura 5.15). Nos reatores com oxigênio foram verificados 39,7\% (EP: 1,8\%), 66,3\% (EP: 2,5\%) e 30,3\% (EP: 1,2\%), respectivamente (Figura 5.15).

Ao final dos ensaios, nos reatores controle foi observado 35,3\% (EP: 2,5\%), 58,8\% (EP: 2,3\%) e 28\% (EP: 1,1\%), respectivamente, para as sondas EUB338, ARC915 e SRB385 (Figura 5.15). Enquanto nos reatores com oxigênio foram verificados 40,1\% (EP: 1,6\%), 54,5\% (EP: 1,8\%) e 16,9\% (EP: 0,7\%), respectivamente (Figura 5.15). A Tabela 5.14 descreve as porcentagens da contagem das células hibridadas, e a Tabela 5.15 mostra as morfologias das células.

A somatória total das populações hibridadas com as sondas EUB338 mais ARC915 foram, respectivamente, 99,8\% e 106\%, para amostras dos reatores controle e com oxigênio, com 6 dias de operação; 94,1\% e 94,6\%, para reatores controle e com oxigênio, ao final dos ensaios. 
Tabela 5.13. Morfologias observadas nos reatores contendo etanol.

$\begin{array}{lll}\text { Morfologias } & \text { Reatores controle } & \text { Reatores com oxigênio }\end{array}$

\begin{tabular}{ccc}
\hline Arquéias metanogênicas & & \\
\hline Methanosarcina sp. & +++ & +++ \\
\hline Methanosaeta sp. & +++ & ++++ \\
\hline Cistos de sarcinas & - & - \\
\hline
\end{tabular}

\section{Bactérias}

Bacilos com extremidades $++$ $++$ arredondadas

\begin{tabular}{ccc}
\hline Bacilos delgados & ++++ & +++ \\
\hline Bacilos curvos & ++ & ++ \\
\hline Cocobacilos & +++ & ++++ \\
\hline Cocos & ++++ & - \\
\hline Espiroqueta & - & ++ \\
\hline Filamentos & + & +++
\end{tabular}

$\overline{(++++) \text { predominantes, }(+++) \text { freqüentes, }(++) \text { pouco freqüentes, }(+) \text { raros, }(-) \text { não observados. }}$ 


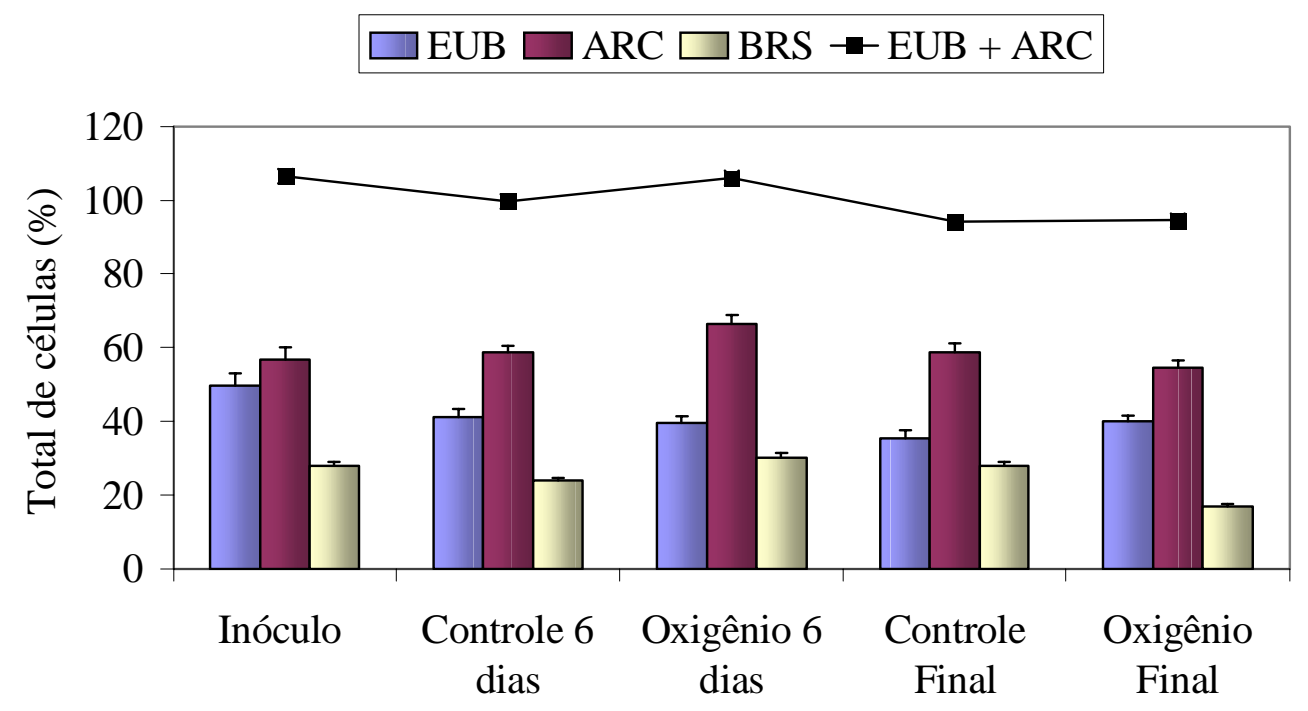

Figura 5.15. Comunidade microbiana nos reatores controle e com oxigênio contendo etanol. Abundância relativa de células pertencentes aos Domínios Bacteria (EUB338), Archaea (ARC915), BRS da subdivisão delta de Proteobacteria (SRB385) e soma dos dois Domínios (EUB338 + ARC915). As barras indicam o erro padrão.

Tabela 5.14. Porcentagens de microrganismos obtidos com o FISH nos reatores controle e com oxigênio contendo etanol.

\begin{tabular}{ccccccc}
\hline Amostra & \multicolumn{2}{c}{ EUB338 } & \multicolumn{2}{c}{ ARC915 } & \multicolumn{2}{c}{ SRB385 } \\
& $(\mathbf{\%})$ & Erro & $\mathbf{( \% )}$ & Erro & $(\mathbf{\%})$ & Erro \\
& & padrão & & padrão & & padrão \\
\hline Controle/6 dias & 41,2 & 2,3 & 58,6 & 1,7 & 23,9 & 0,8 \\
Controle/Final & 35,3 & 2,5 & 58,8 & 2,3 & 28 & 1,1 \\
Oxigênio/6 dias & 39,7 & 1,8 & 66,3 & 2,5 & 30,3 & 1,2 \\
Oxigênio/Final & 40,1 & 1,6 & 54,5 & 1,8 & 16,9 & 0,7 \\
\hline \hline
\end{tabular}

Nos reatores controle com 6 dias, a proporção de arquéias (58,6\%) foi semelhante a verificada no inóculo (56,7\%), e manteve-se com valor semelhante no final do ensaio (58,8\%). A população de bactéria diminuiu ao longo do ensaio, comparando-se os valores do inóculo (49,8\%), após 6 dias (41,2\%) e no final do ensaio (35,3\%). A proporção de BRS manteve-se aproximadamente constante. 
Nos reatores com oxigênio com 6 dias de operação, a proporção de arquéias (66,3\%) aumentou em relação ao inóculo (56,7\%), entretanto, diminuiu no final do experimento (54,5\%). A população de bactérias diminuiu após 6 dias (39,7\%) em relação ao inóculo (49,8\%), e manteve proporção semelhante ao final do ensaio (40,1\%). A população de BRS após 6 dias de operação (30,3\%) apresentou proporção ligeiramente superior ao inóculo (27,9\%), e diminuiu no final (16,9\%). Nesses ensaios, também, a proporção de BRS foi menor nos reatores com oxigênio, embora o consumo de sulfato tenha sido maior (76,6\%), comparando-se com os reatores controle. Conforme aconteceu nos reatores com acetato e oxigênio, nesses reatores com etanol e oxigênio, o sulfato também pode ter sido reduzido por outras bactérias não pertencentes ao grupo das BRS. Desse modo explica-se o alto consumo de sulfato e baixa porcentagem de BRS detectada pelo FISH.

Tabela 5.15. Morfologias das células predominantes nos reatores contendo etanol detectados pelo FISH.

\begin{tabular}{|c|c|c|c|c|}
\hline \multirow[t]{2}{*}{ Sondas } & \multicolumn{4}{|c|}{ Morfologia das Células Hibridadas } \\
\hline & Controle/6 dias & Controle/Final & Oxigênio/6 dias & Oxigênio/Final \\
\hline EUB338 & $\begin{array}{l}\text { Cocos, bacilos, } \\
\text { filamentos, } \\
\text { cocobacilos }\end{array}$ & $\begin{array}{c}\text { Cocos, bacilos, } \\
\text { cocobacilos }\end{array}$ & $\begin{array}{l}\text { Cocos, bacilos, } \\
\text { cocobacilos }\end{array}$ & $\begin{array}{l}\text { Cocos, bacilos, } \\
\text { cocobacilos, } \\
\text { filamentos }\end{array}$ \\
\hline ARC915 & $\begin{array}{c}\text { Filamentos, } \\
\text { bacilos, sarcinas }\end{array}$ & $\begin{array}{l}\text { Filamentos, } \\
\text { Cocos, bacilos, } \\
\text { sarcinas }\end{array}$ & $\begin{array}{l}\text { Filamentos, } \\
\text { cocos, bacilos, } \\
\text { sarcinas }\end{array}$ & $\begin{array}{l}\text { Filamentos, } \\
\text { cocos, bacilos, } \\
\text { sarcinas }\end{array}$ \\
\hline SRB385 & Cocos, bacilos & $\begin{array}{c}\text { Cocos, bacilos, } \\
\text { cocobacilos }\end{array}$ & $\begin{array}{l}\text { Cocos, bacilos, } \\
\text { cocobacilos }\end{array}$ & $\begin{array}{c}\text { Cocos, bacilos, } \\
\text { cocobacilos }\end{array}$ \\
\hline
\end{tabular}

\subsection{Reatores em batelada contendo lactato de sódio}

Nos reatores em batelada contendo lactato de sódio e adição de oxigênio a DQO inicial foi de $1326 \pm 5 \mathrm{mg} / \mathrm{L}$, potencial de oxi-redução de $327 \pm 6 \mathrm{mV}, 3,7 \mathrm{mg} / \mathrm{L}$ de OD, sólidos totais voláteis de 4507 mg/L e relação DQO/sulfato de 1,5 (Tabela 5.16).

Os reatores foram operados durante 768 horas, ao final do ensaio a DQO foi igual a $165 \pm$ $4 \mathrm{mg} / \mathrm{L}$, o que resultou eficiência de 87,5\%, potencial de oxi-redução de $-191 \pm 1 \mathrm{mV}$, OD igual a 
zero e sólidos totais voláteis de $3830 \pm 127 \mathrm{mg} / \mathrm{L}$. Semelhante ao observado nos outros ensaios com acetato de sódio e etanol, as concentrações de sólidos totais voláteis no final do experimento também foram inferiores em relação aos valores iniciais. O lactato adicionado (922,5 $\pm 27 \mathrm{mg} / \mathrm{L})$ foi totalmente consumido após 55 horas, isto é, concentração abaixo do limite da curva de calibração (Figura 5.16).

Nos reatores controle com lactato, a DQO inicial foi $1343 \pm 36 \mathrm{mg} / \mathrm{L}$, potencial de oxiredução de $14 \pm 5 \mathrm{mV}$, sólidos totais voláteis $4507 \mathrm{mg} / \mathrm{L}$ e relação DQO/sulfato de 1,4 (Tabela 5.16). Estes reatores também foram operados durante 768 horas, apresentaram DQO final de 147 $\pm 3 \mathrm{mg} / \mathrm{L}$, resultando eficiência de 89\%, potencial de oxi-redução igual a -181 $\pm 3 \mathrm{mV}$ e sólidos totais voláteis final de $3750 \pm 99 \mathrm{mg} / \mathrm{L}$. O lactato adicionado (1010,3 $\pm 14 \mathrm{mg} / \mathrm{L})$ foi totalmente consumido em 72 horas, ou seja, concentração inferior ao limite de detecção da curva de calibração (Figura 5.16).

Tabela 5.16. Relação DQO/sulfato, DQO inicial, potencial de oxi-redução, eficiência de remoção de DQO e sólidos totais voláteis dos reatores em batelada contendo lactato de sódio.

\begin{tabular}{|c|c|c|c|c|c|c|c|}
\hline \multirow[t]{2}{*}{$\overline{\text { Ensaio }}$} & \multirow[t]{2}{*}{$\begin{array}{c}\text { Relação } \\
\text { DQO/Sulfato }\end{array}$} & \multirow[t]{2}{*}{$\begin{array}{c}\text { DQO } \\
\text { inicial } \\
(\mathrm{mg} / \mathrm{L})\end{array}$} & \multicolumn{2}{|c|}{$\begin{array}{c}\text { Potencial de } \\
\text { Oxi-Redução } \\
\text { (mV) }\end{array}$} & \multirow{2}{*}{$\begin{array}{c}\text { Eficiência } \\
\text { Remoção } \\
\text { DQO } \\
(\%)\end{array}$} & \multicolumn{2}{|c|}{$\begin{array}{c}\text { Sólidos Totais } \\
\text { Voláteis } \\
(\mathrm{mg} / \mathrm{L})\end{array}$} \\
\hline & & & Inicial & Final & & Inicial & Final \\
\hline Lactato/Oxigênio & 1,5 & 1326 & 327 & -191 & 87,5 & 4507 & 3830 \\
\hline Lactato/Controle & 1,4 & 1343 & 14 & -181 & 89 & 4507 & 3750 \\
\hline
\end{tabular}

Nesses reatores com lactato e oxigênio, conforme observado também com acetato e etanol, o potencial de oxi-redução foi mais positivo, comparando-se com os reatores controle, possivelmente devido à presença do oxigênio que deixou o meio oxidado. Os reatores controle também, no início do ensaio, apresentaram potencial redox positivo (oxidado), possivelmente devido à ausência de solução redutora e presença de sulfato que possui potencial redox oxidado. No final dos ensaios, os reatores com oxigênio apresentaram potencial redox reduzido, devido a redução do oxigênio e formação de sulfeto. Nos reatores controle também ao final do ensaio, o potencial redox encontrava-se reduzido, entretanto, menos reduzido que nos reatores com oxigênio. 


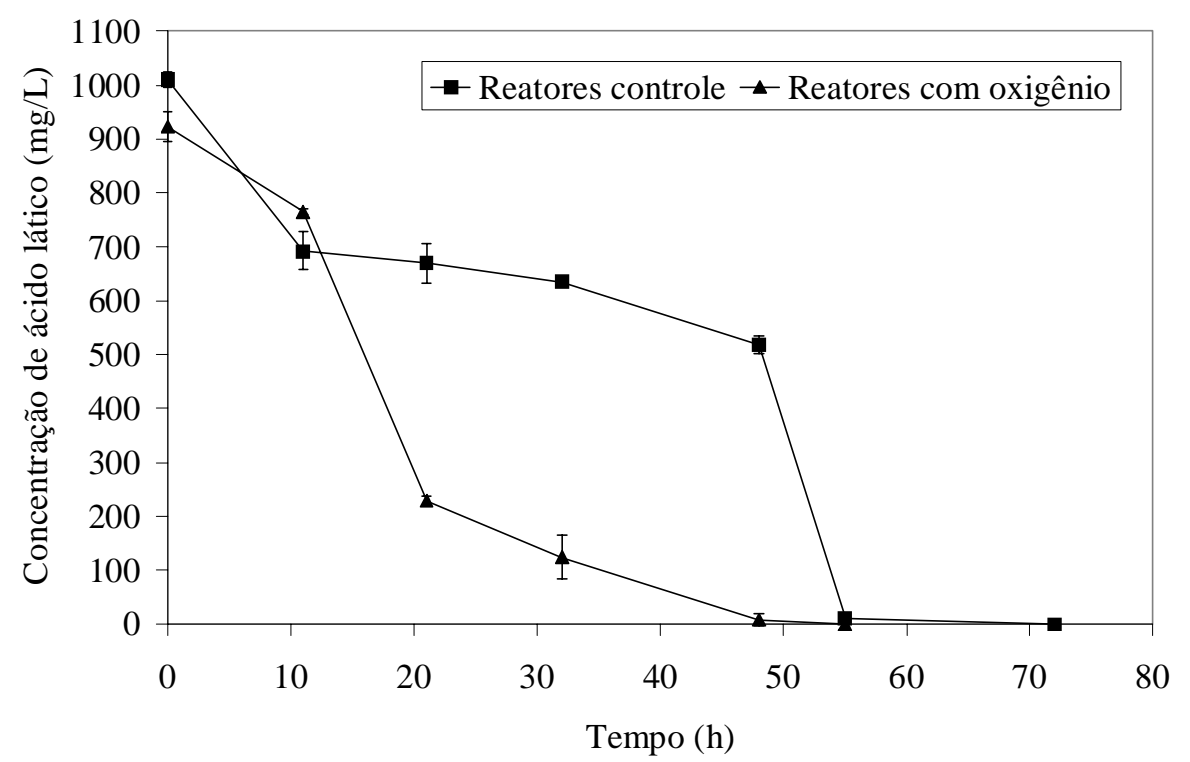

Figura 5.16. Variação temporal do ácido lático nos reatores em batelada.

Como pode ser observado pela Figura 5.16, nos reatores com oxigênio o consumo de ácido lático ocorreu em menor tempo que nos reatores controle. Análises cromatográficas detectaram a presença dos ácidos acético, propiônico, fórmico, isobutírico, butírico, isovalérico e valérico, em concentrações que variaram de 1,5 até $150 \mathrm{mg} / \mathrm{L}$, em ambos reatores. As concentrações de ácido acético chegaram a 150 mg/L nos reatores controle, enquanto que nos reatores com oxigênio os valores foram menores de $50 \mathrm{mg} / \mathrm{L}$.

Com relação à produção de metano, nos ensaios com lactato e adição de oxigênio, a velocidade máxima de produção de metano foi de $0,08 \mathrm{mmol} / / \mathrm{L} . \mathrm{h}$ em 50 horas e velocidade média de 0,013 \pm 0,02 mmol/L, atingindo concentração máxima de $3 \mathrm{mmol} / \mathrm{L}$ de metano (Tabela 5.17 Figura 5.17) em 139 horas, estabilizando-se também no mesmo período. 
Tabela 5.17. Velocidade máxima de produção de metano e concentração máxima de metano nos reatores contendo lactato de sódio.

\begin{tabular}{|c|c|c|c|}
\hline Ensaio & $\begin{array}{c}\text { Velocidade } \\
\text { Máxima de } \\
\text { Produção de } \\
\text { Metano } \\
\text { (mmol/L.h) }\end{array}$ & $\begin{array}{c}\text { Concentração } \\
\text { Máxima de Metano } \\
(\mathrm{mmol} / \mathrm{L})\end{array}$ & $\begin{array}{c}\text { Período da } \\
\text { Produção Máxima } \\
\text { de Metano } \\
\text { (h) }\end{array}$ \\
\hline Lactato/Oxigênio & 0,08 & 3 & 139 \\
\hline Lactato/Controle & 0,16 & 13 & 139 \\
\hline
\end{tabular}

Nos reatores controle, a velocidade máxima de produção de metano foi de $0,16 \mathrm{mmol} / \mathrm{L} . \mathrm{h}$ em 56 horas e velocidade média de $0,034 \pm 0,05 \mathrm{mmol} / \mathrm{L}$, atingindo concentração máxima de 13 mmol/L de metano (Tabela 5.17 e Figura 5.17) em 139 horas, estabilizando-se em seguida. Nestes reatores, as curvas de produção de metano apresentaram coeficiente de correlação $\left(\mathrm{R}^{2}\right)$ iguais a 0,97 e 0,99 para os reatores com oxigênio e controle, respectivamente.

Nos reatores com lactato de sódio e oxigênio ocorreu inibição da produção de metano, fato observado pela menor concentração de metano verificada (3 $\mathrm{mmol} / \mathrm{L})$, além da baixa velocidade de produção de metano $(0,08 \mathrm{mmol} / \mathrm{L} . \mathrm{h})$, comparando-se com as velocidades observadas nos reatores alimentados com os outros substratos (acetato e etanol) na presença de oxigênio.

Os reatores controle também apresentaram velocidades de produção de metano menores em relação aos reatores controle contendo acetato e etanol, o que pode ser explicado pelo fato de o lactato não ser substrato orgânico utilizado pelas metanogênicas. Contudo, ele pode ser metabolizado por bactérias fermentativas e BRS oxidadoras incompletas, a acetato e hidrogênio, os quais são utilizados na metanogênese.

Vazzoler et al. (1996) propuseram uma rota biológica de degradação de compostos orgânicos para explicar a interação metabólica entre as culturas presentes em lodo granulado, submetido a elevadas concentrações de sulfato de sódio. Os autores propuseram que o lactato de sódio seria oxidado parcialmente a acetato pelas BRS, estando assim totalmente disponibilizado para as arquéias metanogênicas, uma vez que nem todas as espécies de BRS oxidam acetato. 
Jones et al. (1984) estudaram a metanogênese a partir de sacarose como substrato orgânico, utilizando consórcio microbiano composto por Escherichia coli, Acetobacterium woodii, Desulfovibrio vulgaris, Methanosarcina barkeri e Methanobacterium formicicum. Os autores observaram que a fermentação da sacarose foi realizada por E. coli, produzindo acetato, lactato, etanol, formiato, $\mathrm{CO}_{2}$ e $\mathrm{H}_{2}$. Segundo os autores, o lactato produzido teria sido oxidado por $A$. woodii. Na ausência desse organismo, a velocidade máxima de produção de metano foi $30 \%$ inferior comparado com experimentos quando esse microrganismo estava presente no consórcio microbiano.

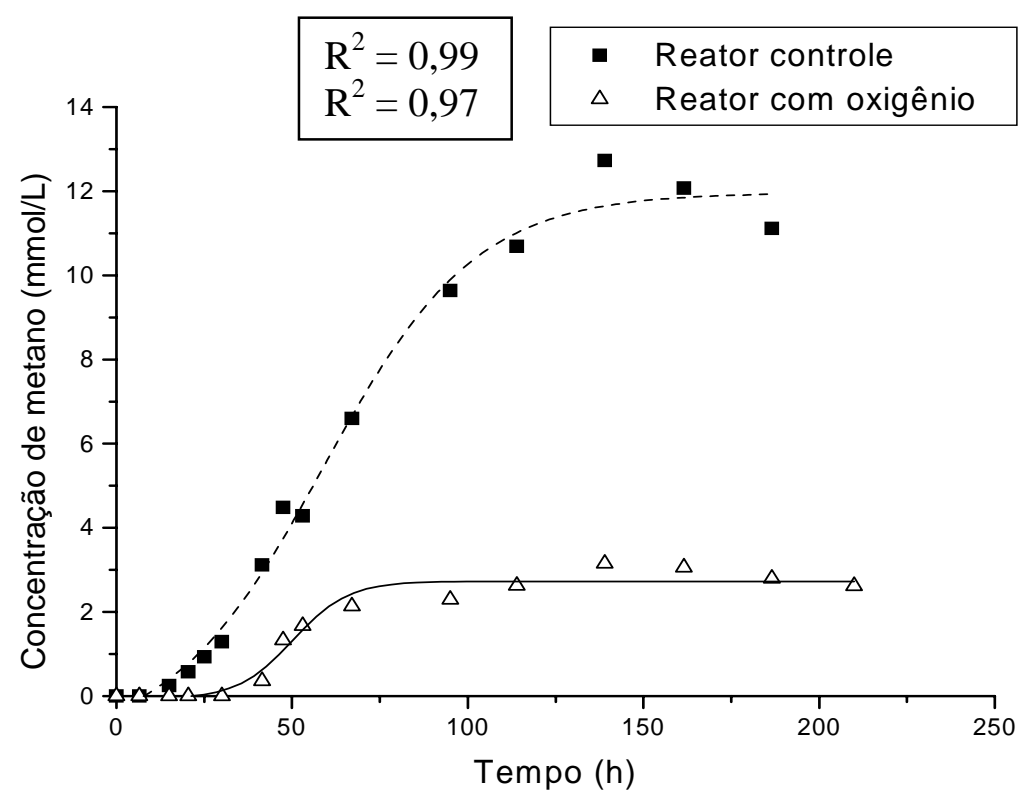

Figura 5.17. Variação temporal da concentração de metano nos reatores contendo lactato com oxigênio e controle.

A concentração inicial de sulfato nos reatores alimentados com lactato e adição de oxigênio foi de $860 \pm 28 \mathrm{mg} / \mathrm{L}$ e a final de $500 \pm 104 \mathrm{mg} / \mathrm{L}$, o que correspondeu ao consumo de 41,9\% (Figura 5.18). A velocidade máxima de consumo do sulfato foi de 1,07 mg/L.h, observada no início do ensaio $(\mathrm{t}=0$ ) (apêndice E) e velocidade média de 0,48 \pm 0,3 $\mathrm{mg} / \mathrm{L} . \mathrm{h}$. O sulfeto presente no biogás começou a ser detectado após 161,5 horas de ensaio, atingindo valor máximo 
de 1,41 mmol/L em 715 horas. A concentração teórica de sulfeto dissolvido foi calculada, obtendo-se o valor de 4,3 mmol/L. Estequiometricamente, o sulfato adicionado produziria 3,7 $\mathrm{mmol} / \mathrm{L}$ de sulfeto total (biogás e dissolvido), entretanto, nesses reatores o valor de sulfeto total (biogás e dissolvido) observado foi de $5,1 \mathrm{mmol} / \mathrm{L}$, valor superior ao valor teórico estequiométrico. Nesse caso, o valor de sulfeto total foi maior ao observado nos ensaios, em relação ao teórico, o que pode ser devido a aproximações realizadas nos cálculos para quantificação do sulfeto dissolvido, uma vez que este não foi medido nos ensaios, mas foi calculado teoricamente.

Nos reatores controle a concentração inicial de sulfato foi $920 \pm 85$ mg/L e final de 206,7 $\pm 23 \mathrm{mg} / \mathrm{L}$, resultando consumo de 77,5\% (Figura 5.19). A velocidade máxima de consumo de sulfato foi de 7,9 mg/L.h observada também no início do ensaio $(\mathrm{t}=0$ ) (apêndice $\mathrm{F}$ ) e velocidade média de 1,14 \pm 1,9 mg/L.h. O sulfeto no biogás começou a ser detectado após 30 horas, e atingiu concentração máxima de 1,84 mmol/L em 503,5 horas. A concentração teórica de sulfeto dissolvido foi calculada obtendo-se o valor de $4,5 \mathrm{mg} / \mathrm{L}$. Estequiometricamente, o sulfato adicionado produziria 3,7 mmol/L de sulfeto total (biogás e dissolvido). Entretanto, o sulfeto total observado (biogás e dissolvido) nesses reatores foi de 6,3 mmol/L, valor também superior ao teórico estequiométrico. Essa incompatibilidade entre o valor de sulfeto total observado e teórico pode ter ocorrido pelos mesmos motivos citados acima.

A Tabela 5.18 mostra os valores de consumo de sulfato, tempo de início da detecção do sulfeto no biogás e concentrações máximas de sulfeto observadas nos reatores com oxigênio e controle, alimentados com lactato de sódio. Conforme observado na mesma Tabela, nos reatores controle foi verificado maior velocidade de consumo do sulfato, em relação a todas as condições testadas. Desse modo, pode-se supor que dos três substratos orgânicos utilizados, o lactato foi o mais utilizado pelas BRS, confirmando a preferência nutricional para esse substrato (Widdel, 1988). 
Tabela 5.18. Consumo de sulfato, início do tempo de detecção de sulfeto no biogás e concentração máxima de sulfeto nos reatores contendo lactato de sódio.

\begin{tabular}{|c|c|c|c|c|c|}
\hline Ensaio & $\begin{array}{c}\text { Consumo } \\
\text { de Sulfato } \\
(\%)\end{array}$ & $\begin{array}{c}\text { Concentração } \\
\text { Inicial de } \\
\text { Sulfato } \\
(\mathrm{mg} / \mathrm{L})\end{array}$ & $\begin{array}{c}\text { Velocidade } \\
\text { Máxima } \\
\text { Consumo } \\
\text { Sulfato } \\
\text { (mg/L.h) }\end{array}$ & $\begin{array}{c}\text { Início da } \\
\text { Detecção } \\
\text { do Sulfeto } \\
\text { (h) }\end{array}$ & $\begin{array}{c}\text { Concentração } \\
\text { Máxima de } \\
\text { Sulfeto no } \\
\text { Biogás } \\
\text { (mmol/L) }\end{array}$ \\
\hline Lactato/Oxigênio & 41,9 & 860 & 1,07 & 161,5 & 1,41 \\
\hline Lactato/Controle & 77,5 & 920 & 7,9 & 30 & 1,84 \\
\hline
\end{tabular}

De acordo com a Figura 5.19, nos reatores controle, as maiores velocidades de consumo de sulfato ocorreram nas primeiras 100 horas, o que pode ter ocorrido devido a disponibilidade de lactato; entre 100 e 300 horas não foi observado consumo de sulfato, e após esse período, até o término dos ensaios, o consumo de sulfato foi lento. Ácidos orgânicos e hidrogênio podem ter sido liberados pela morte celular, e estes substratos utilizados para redução do sulfato após consumo do lactato.

Nos reatores com oxigênio, o consumo do sulfato foi praticamente lento durante todo o período do ensaio. Nesse caso, morte celular também poder ter fornecido ácidos orgânicos e hidrogênio para redução de sulfato. Além disso, acetato e hidrogênio liberados da oxidação do lactato a acetato, por BRS oxidadoras incompletas ou bactérias facultativas, foram utilizados pelas BRS para redução do sulfato.

Fareleira et al. (2003) observaram inibição do consumo de lactato por Desulfovibrio gigas, em reatores em batelada, na presença de oxigênio. Neste estudo, o consumo do lactato pelas BRS também pode ter sido inibido pela presença do oxigênio. Desse modo, o substrato foi utilizado por outras bactérias presentes nos reatores.

Nos reatores com oxigênio, foi observado também, que o sulfeto demorou 162 h para começar a ser detectado no biogás, sendo que tal comportamento não foi observado nos reatores controle. Conforme ocorreu nos reatores com acetato e oxigênio, o sulfeto produzido pode ter sido oxidado na redução do oxigênio, tendo como produto sulfato. 


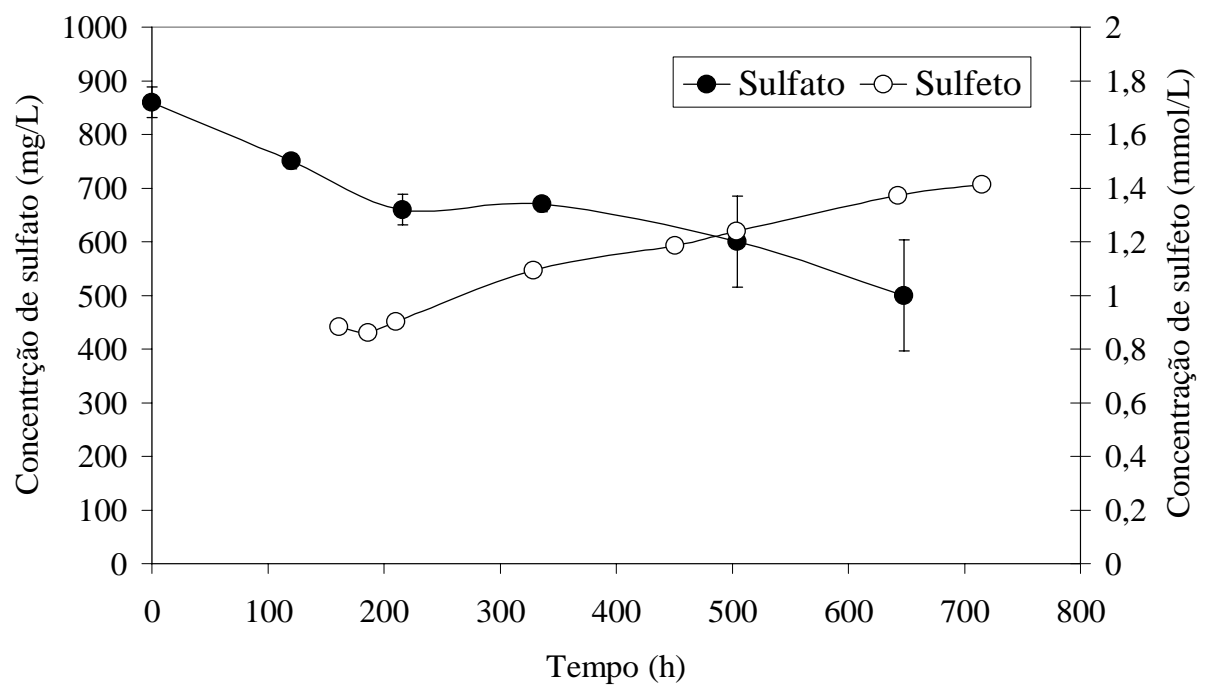

Figura 5.18. Variação temporal da concentração de sulfato e sulfeto nos reatores contendo lactato e oxigênio.

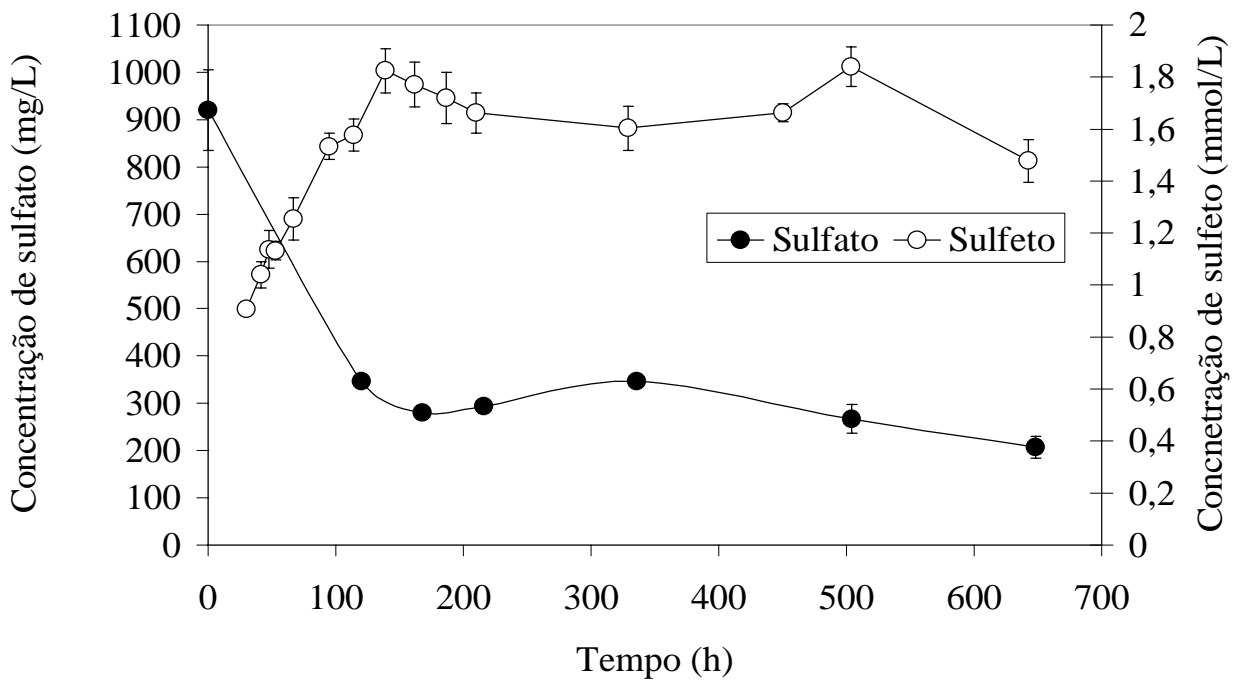

Figura 5.19. Variação temporal da concentração de sulfato e sulfeto nos reatores controle contendo lactato. 


\subsubsection{Caracterização microbiana}

As análises de microscopia mostraram as seguintes morfologias nos reatores controle com lactato: filamentos, filamentos segmentados, bacilos delgados, cocos, bacilos com extremidades arredondados, bacilos delgados, formas semelhantes a Methanosarcina sp. e predominância de bacilos curvos, cocobacilos e morfologia semelhante a Methanosaeta sp. Nos reatores com oxigênio foram observadas as mesmas formas celulares, com a diferença da presença de cocobacilos em pares, o que não foi observado nos outros reatores. Houve predomínio desses cocobacilos em pares, bacilos com extremidades arredondadas, filamentos segmentados e dois tipos de bacilos curvos. A Tabela 5.19 e Figura 5.20 mostram as morfologias observadas.

Domingues (2001) estudou reatores contendo lactato e sulfato sob condições termofílicas. O autor observou predominância de bacilos com extremidades afiladas semelhantes a Desulfotomaculum sp., presença de bacilos retos fluorescentes, bacilos com extremidades arredondadas, endósporos e raros bacilos curvos. Neste trabalho, novamente, não foi observado presença de bacilos retos fluorescentes e nem formas semelhantes a Desulfotomaculum sp., como explicado anteriormente.

Nos reatores controle após 6 dias de operação foram observadas 32,7\% (EP: 2\%), 62,5\% (EP: 1,8\%) e 16,2\% (EP: 1,1\%) para as sondas EUB338, ARC915 e SRB385, respectivamente (Figura 5.20). Nos reatores com oxigênio foram verificados 67,6\% (EP: 1,6\%), 24,8\% (EP: 2,3\%) e 17,1\% (EP: 0,8\%), respectivamente (Figura 5.21).

Ao final dos ensaios, nos reatores controle foi observado 35,2\% (EP: 1,9\%), 56,2\% (EP: 1,8\%) e 19,5\% (EP: 0,8\%), respectivamente para as sondas EUB338, ARC915 e SRB385. Nos reatores com oxigênio os valores obtidos foram os seguintes: 63,9\% (EP: 2,3\%), 35,2\% (EP: 1,6\%) e 21,9\% (EP: 0,9\%), (Figura 5.21). A Tabela 5.20 descreve as porcentagens das células hibridadas com as sondas. A Tabela 5.21 e Figura 5.22 mostram as morfologias predominantes detectadas pelo FISH.

A somatória total das populações hibridadas com as sondas EUB338 mais ARC915 foram, respectivamente, 95,2\% e 92,4\%, para amostras dos reatores controle e com oxigênio, com 6 dias de operação; 91,4\% e 99,1\%, para reatores controle e com oxigênio, ao final dos ensaios. 
Tabela 5.19. Caracterização morfológica dos reatores contendo lactato.

$\begin{array}{lll}\text { Morfologias } & \text { Reatores controle } & \text { Reatores com oxigênio }\end{array}$

\begin{tabular}{|c|c|c|}
\hline Arquéias metanogênicas & & \\
\hline Methanosarcina sp. & ++ & + \\
\hline Methanosaeta sp. & ++++ & ++++ \\
\hline Cistos de sarcinas & - & + \\
\hline Bactérias & & \\
\hline $\begin{array}{c}\text { Bacilos com extremidades } \\
\text { arredondadas }\end{array}$ & +++ & ++++ \\
\hline Bacilos delgados & +++ & $\begin{array}{ll}+++ \\
++\end{array}$ \\
\hline Bacilos curvos & ++++ & ++++ \\
\hline Cocobacilos & ++++ & +++ \\
\hline Cocobacilos em pares & - & 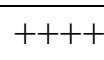 \\
\hline Cocos & + & +++ \\
\hline Espiroqueta & - & - \\
\hline Filamentos & + & ++ \\
\hline Filamentos segmentados & +++ & 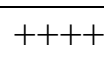 \\
\hline
\end{tabular}




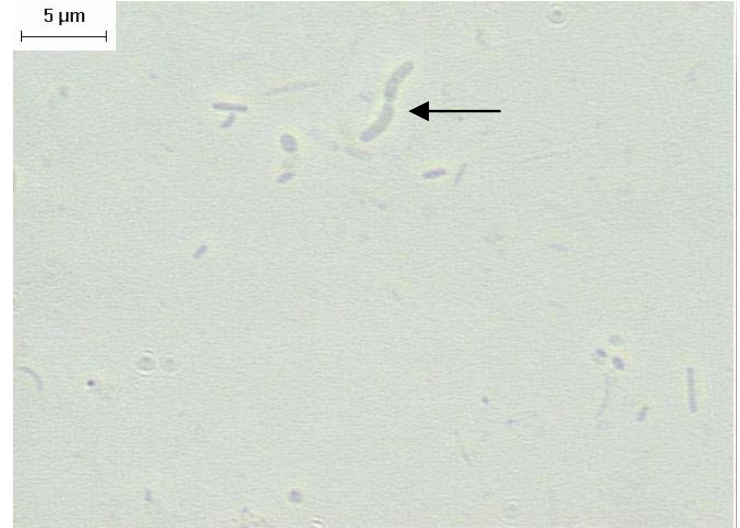

(a)

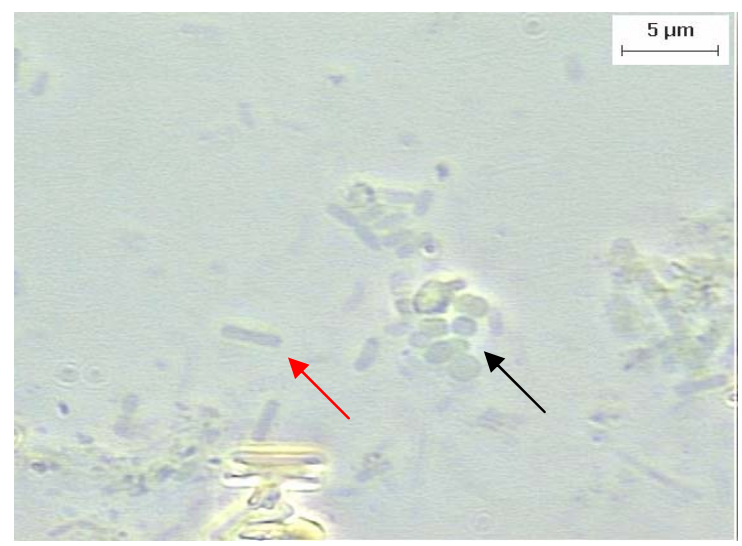

(c)

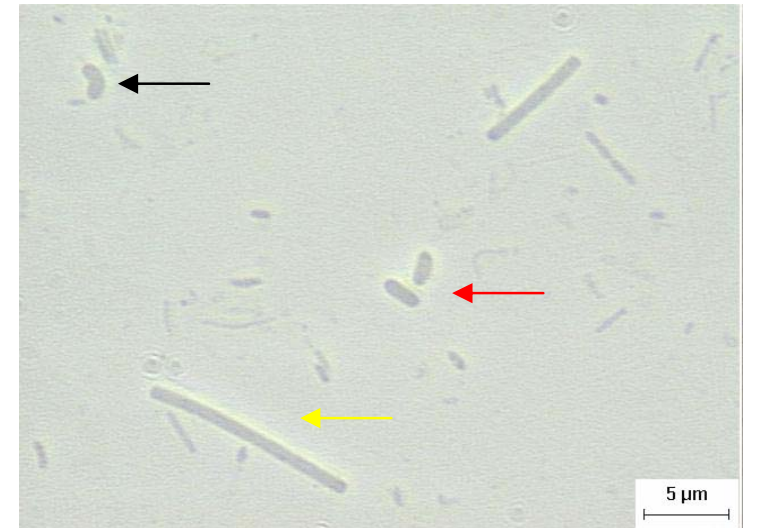

(b)

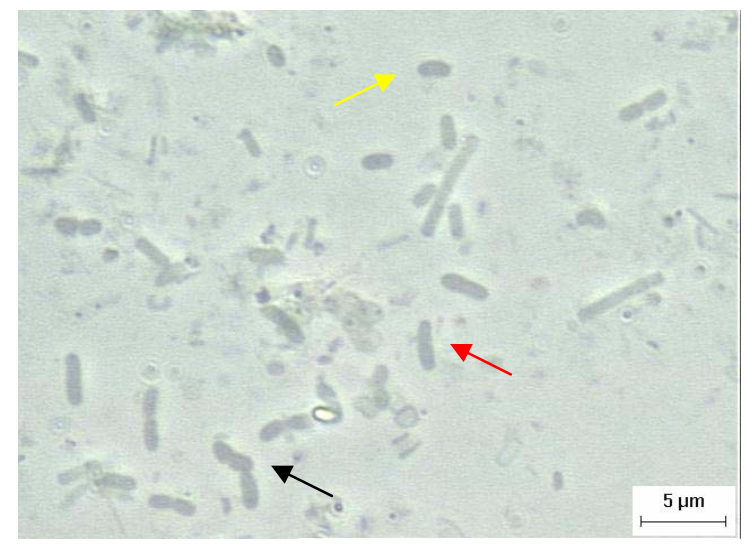

(d)

Figura 5.20. Morfologias observadas sob microscopia óptica de contraste de fase nos reatores alimentados com lactato controle (a-b) e com oxigênio (c-d): (a) bacilos curvos semelhantes a Desulfovibrio sp., (b) bacilo curvo (seta preta), cocobacilos (seta vermelha) e filamento semelhante a Methanosaeta sp. (seta amarela), (c) cocos (seta preta) e bacilos com extremidades arredondadas (seta vermelha), (d) cocobacilos em pares (seta preta), bacilos com extremidades arredondadas (seta vermelha) e cocobacilos (seta amarela). 
Tabela 5.20. Porcentagens de microrganismos obtidos com o FISH nos reatores controle e com oxigênio contendo lactato.

\begin{tabular}{ccccccc}
\hline \hline Amostras & \multicolumn{2}{c}{ EUB338 } & \multicolumn{2}{c}{ ARC915 } & \multicolumn{2}{c}{ SRB385 } \\
& $(\%)$ & Erro & $(\%)$ & Erro & $(\%)$ & Erro \\
& & padrão & & padrão & & padrão \\
\hline Controle/6 dias & 32,7 & 2 & 62,5 & 1,8 & 16,2 & 1,1 \\
Controle/Final & 35,2 & 1,9 & 56,2 & 1,8 & 19,5 & 0,8 \\
Oxigênio/6 dias & 67,6 & 1,6 & 24,8 & 2,3 & 17,1 & 0,8 \\
Oxigênio/Final & 63,9 & 2,3 & 35,2 & 1,6 & 21,9 & 0,9 \\
\hline \hline
\end{tabular}

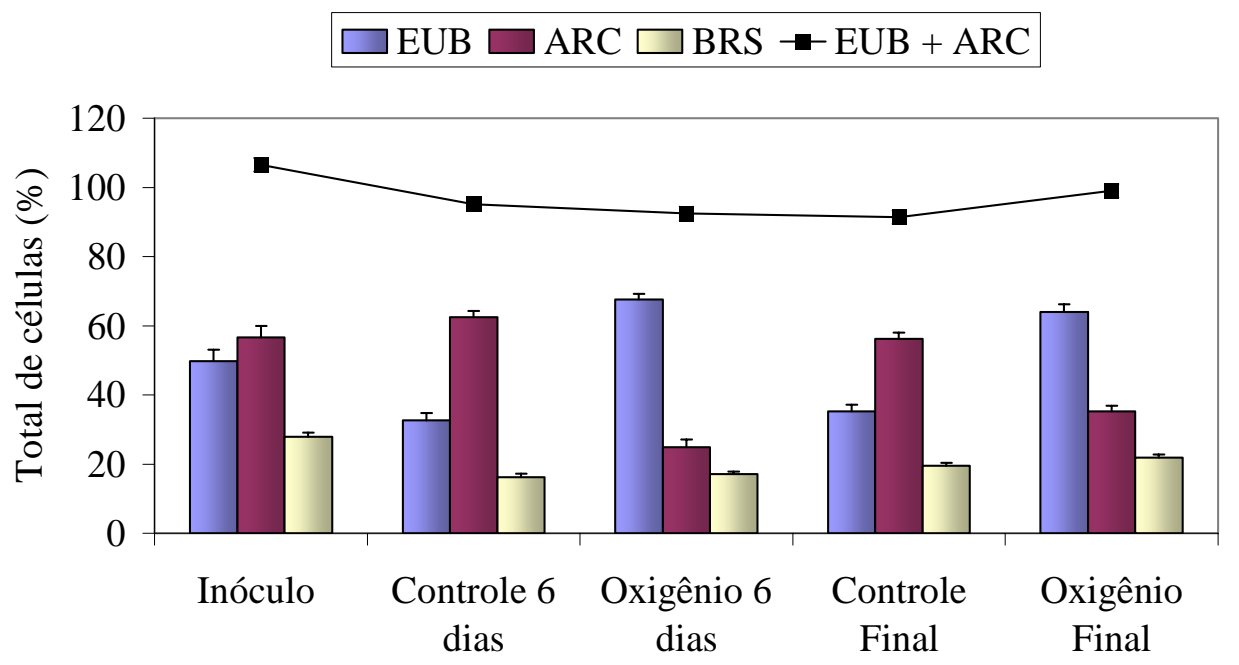

Figura 5.21. Comunidade microbiana nos reatores controle e com oxigênio alimentados com lactato. Abundância relativa de células pertencentes aos Domínios Bacteria (EUB338), Archaea (ARC915), BRS da subdivisão delta de Proteobacteria (SRB385) e soma dos dois Domínios (EUB338 + ARC915). As barras indicam o erro padrão. 
Tabela 5.21. Morfologias das células predominantes nos reatores contendo lactato detectadas pelo FISH.

Sondas Morfologia das Células Hibridadas

\section{Controle/6 dias Controle/Final Oxigênio/6 dias Oxigênio/Final}

\begin{tabular}{ccccc}
\hline EUB338 & $\begin{array}{c}\text { Cocos, bacilos, } \\
\text { cocobacilos }\end{array}$ & $\begin{array}{c}\text { Cocos, bacilos, } \\
\text { cocobacilos, } \\
\text { filamentos }\end{array}$ & $\begin{array}{c}\text { Cocos, bacilos, } \\
\text { cocobacilos, } \\
\text { filamentos }\end{array}$ & $\begin{array}{c}\text { Cocos, bacilos, } \\
\text { cocobacilos }\end{array}$ \\
ARC915 & $\begin{array}{c}\text { Filamentos, } \\
\text { cocos, bacilos, }\end{array}$ & $\begin{array}{c}\text { Filamentos, } \\
\text { cocos, bacilos, }\end{array}$ & $\begin{array}{c}\text { Filamentos, } \\
\text { bacilos }\end{array}$ & Filamentos, \\
& $\begin{array}{c}\text { sarcinas } \\
\text { Cocos, bacilos, }\end{array}$ & $\begin{array}{c}\text { Cocos, bacilos, } \\
\text { cocobacilos }\end{array}$ & $\begin{array}{c}\text { Cocos, bacilos, } \\
\text { cocobacilos }\end{array}$ & $\begin{array}{c}\text { Cocos, bacilos, } \\
\text { cocobacilos }\end{array}$ \\
\hline \hline
\end{tabular}

Nos reatores controle contendo lactato, também se observou predomínio de organismos metanogênicos (52,6\%), ao final do ensaio. A população de BRS diminuiu em relação ao inóculo, apesar do consumo de $77,5 \%$ de sulfato. A população de Bacteria diminuiu consideravelmente em relação ao inóculo. Domingues (2001), diferente do que foi observado neste trabalho, verificou predomínio de organismos do Domínio Bacteria (80\%) e elevada proporção de BRS (56,3\% - 67,4\%) em reatores em batelada alimentados com lactato e sulfato, sob condições termofílicas, entretanto o lodo utilizado como inóculo era diferente do utilizado neste trabalho. Os organismos metanogênicos não utilizam lactato na metanogênese, entretanto, organismos acetogênicos e também BRS oxidadoras incompletas, podem ter oxidado lactato a acetato, e este foi utilizado pelas metanogênicas, conforme citado anteriormente.

Nos reatores com adição de oxigênio ocorreu o inverso, a população de bactérias prevaleceu (63,9\%, no final do ensaio). Apesar da predominância de bactérias, as BRS corresponderam a apenas 21,9\% do total de organismos do Domínio Bacteria.

Nestes reatores com oxigênio populações de bactérias não pertencentes ao grupo das BRS, provavelmente facultativas, competiram pelo lactato com as BRS, e prevaleceram nessa condição nutricional. Isto pode ser comprovado pelo baixo consumo de sulfato nesses reatores e pela elevada proporção de células pertencentes ao Domínio Bacteria detectadas pelo FISH, em comparação com a proporção de BRS. 


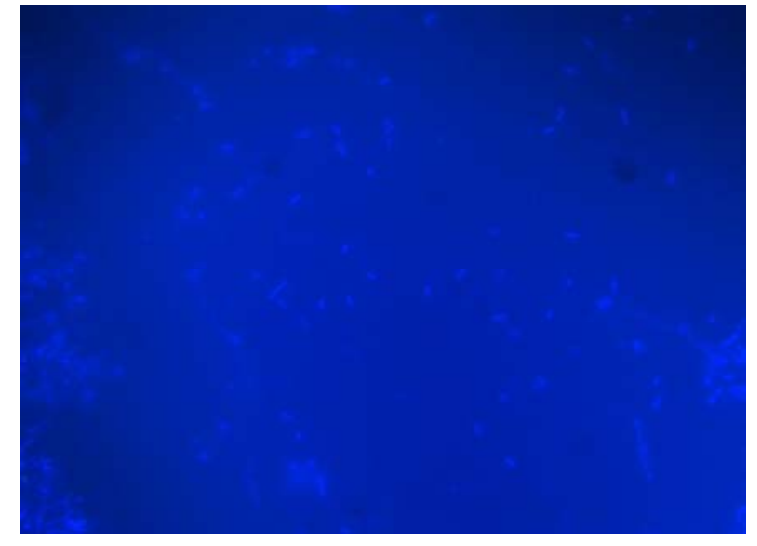

(a)

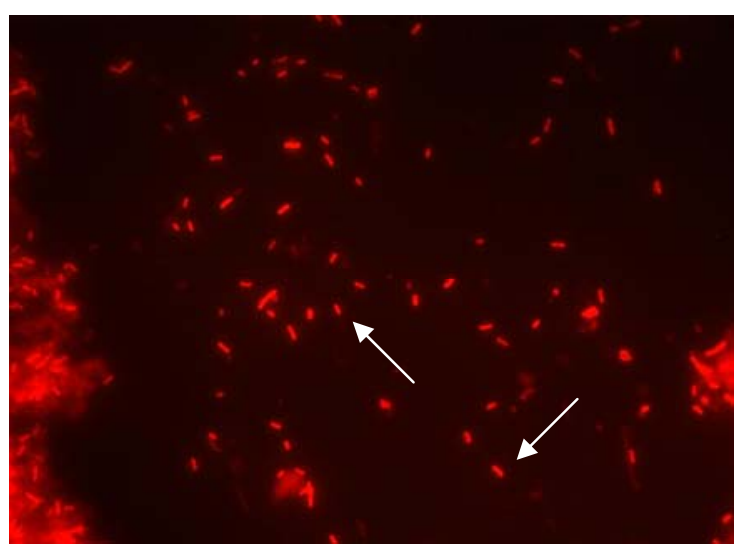

(b)

Figura 5.22. Morfologias hibridadas com a sonda EUB338 nos reatores contendo lactato com oxigênio: (a) coloração com DAPI, (b) bacilos.

\subsection{Comparação do desempenho dos reatores anaeróbios em batelada}

A Tabela 5.22 mostra os resultados das análises de produção de metano e consumo de sulfato nos reatores controle e com oxigênio contendo acetato, etanol e lactato.

Tabela 5.22. Comparação dos resultados de produção de metano e consumo de sulfato dos reatores contendo acetato, etanol e lactato.

\begin{tabular}{cccccc}
\hline \multicolumn{1}{c}{ Ensaio } & $\begin{array}{c}\text { Velocidade } \\
\text { Máxima } \\
\text { Produção } \\
\text { Metano }\end{array}$ & $\begin{array}{c}\text { Concentração } \\
\text { Máxima } \\
\text { Metano } \\
(\mathbf{m m o l} / \mathbf{L} \cdot \mathbf{h})\end{array}$ & $\begin{array}{c}\text { Período } \\
\text { Consumo } \\
\text { Total }\end{array}$ & $\begin{array}{c}\text { Consumo de } \\
\text { Sulfato (\%) }\end{array}$ & $\begin{array}{c}\text { Velocidade } \\
\text { Máxima }\end{array}$ \\
& & $\begin{array}{c}\text { Consumo } \\
\text { Substrato (h) }\end{array}$ & & $\begin{array}{c}\text { Sulfato } \\
\text { (mg/L.h) }\end{array}$ \\
\hline Acetato/Controle & 0,30 & 19 & 120 & 57 & 1,01 \\
Acetato/Oxigênio & 0,27 & 19 & 72 & 97 & 1,97 \\
Etanol/Controle & 0,41 & 14 & 72 & 59,6 & 2,1 \\
Etanol/Oxigênio & 0,40 & 13 & 72 & 76,6 & 2,6 \\
Lactato/Controle & 0,16 & 13 & 72 & 77,5 & 7,9 \\
Lactato/Oxigênio & 0,08 & 3 & 55 & 41,9 & 1,07 \\
\hline \hline
\end{tabular}


Com base na Tabela 5.22 a quantidade de oxigênio escolhida neste trabalho (3 - 3,5 mg/L) não afetou a metanogênese nos reatores contendo acetato e etanol, comparando-se as concentrações máximas de metano e velocidades máximas de produção deste, com os valores observados nos reatores controles anaeróbios. Nos reatores com lactato a presença do oxigênio afetou significativamente a metanogênese, conforme pode-se observar pelos valores das concentrações máximas de metano obtidas e velocidades máximas de produção dos reatores com oxigênio.

As maiores velocidades de produção de metano foram observadas nos reatores contendo etanol. Jones et al. (1984) avaliaram a metanogênese em culturas mista de organismos contendo Desulfovibrio vulgaris, Acetobacterium woodi e Methanosarcina barkeri. Os autores observaram que o etanol foi oxidado a acetato por $D$. vulgaris, o qual foi utilizado na metanogênese. $\mathrm{O}$ mesmo comportamento pode ter acontecido neste trabalho, nos reatores contendo etanol. Desse modo, não houve competição pelo acetato pelas BRS e arquéias metanogênicas, resultando as maiores velocidades de produção de metano. Por outro lado, o lactato foi o substrato utilizado que menos favoreceu a metanogênese, de acordo com as velocidades de produção de metano observadas com este substrato.

A redução de sulfato ocorreu nos reatores contendo acetato e etanol na presença de oxigênio, em valores superiores aos observados nos reatores controle. A presença do oxigênio pode ter favorecido algumas populações de bactérias tolerantes ao oxigênio e que também utilizam sulfato. Em contrapartida, nos reatores com lactato e oxigênio a redução de sulfato ocorreu em menor proporção. Provavelmente, no inóculo estiveram presentes em sua maioria BRS anaeróbias estritas. Desse modo, o crescimento dessas células foi desfavorecido na presença de oxigênio, embora tendo lactato como substrato preferencial para o crescimento dessas células.

As maiores velocidades de consumo de sulfato, em todos os reatores, ocorreu nas primeiras horas de ensaio. Possivelmente, no início dos ensaios, a redução do sulfato ocorreu por meio da utilização dos substratos orgânicos adicionados (acetato, etanol e lactato), com o esgotamento destes, o restante do sulfato foi reduzido utilizando-se ácidos orgânicos e hidrogênio provenientes da morte celular, e como conseqüência, menores velocidades de consumo do sulfato. 
Tabela 5.23. Comparação dos resultados obtidos com FISH, nos reatores contendo acetato, etanol e lactato.

\begin{tabular}{ccccccc}
\hline \hline Amostras & \multicolumn{2}{c}{ ARC915 (\%) } & \multicolumn{2}{c}{ EUB338 (\%) } & \multicolumn{2}{c}{ SRB385 (\%) } \\
& $\mathbf{6}$ dias & Final & $\mathbf{6}$ dias & Final & 6 dias & Final \\
\hline Acetato/controle & 49,6 & 59,2 & 40,5 & 37,6 & 30,7 & 22 \\
Acetato/oxigênio & 59 & 60,7 & 40,4 & 31,1 & 24,9 & 17,3 \\
Etanol/controle & 58,6 & 58,8 & 41,2 & 35,3 & 23,9 & 28 \\
Etanol/oxigênio & 66,3 & 54,5 & 39,7 & 40,1 & 30,3 & 16,9 \\
Lactato/controle & 62,5 & 56,2 & 32,7 & 35,2 & 16,2 & 19,5 \\
Lactato/oxigênio & 24,8 & 35,2 & 67,6 & 63,9 & 17,1 & 21,9 \\
\hline \hline
\end{tabular}

De acordo com a Tabela 5.23, organismos pertencentes ao Domínio Archaea foram predominantes em todas as condições estudadas, inclusive nos reatores em que foi adicionado oxigênio. A exceção ocorreu nos reatores contendo lactato e oxigênio, nos quais houve predomínio dos organismos do Domínio Bacteria. Omil et al. (1997) observaram proporção de 40 a 95\% de organismos pertencentes ao Domínio Archaea em reator UASB em escala de bancada, após exposição do lodo ao ar durante 24 h. Da mesma forma como ocorreu neste trabalho, as metanogênicas foram predominantes, mesmo na presença do oxigênio. Além disso, os autores, ainda no mesmo estudo, verificaram que dentre os organismos metanogênicos, Methanosaeta sp. foi predominante após exposição ao ar. O que também foi observado neste estudo, ou seja, predomínio de Methanosaeta sp. nos reatores contendo acetato, etanol e lactato com adição de oxigênio.

As BRS estiveram presentes em todas as condições estudadas, inclusive nos reatores com adição de oxigênio. Entretanto, é possível observar que nesses reatores ocorreu diminuição da porcentagem de BRS ao final do ensaio, com exceção dos reatores contendo lactato, nos quais os valores ao final dos ensaios foram pouco maiores que os observados com 6 dias de operação. De fato, as BRS estão presentes em ambientes expostos ao oxigênio, como biomassa cianobacteriana 
e sedimentos. Sass et al. (1997) observaram população ativa de BRS em sedimento lacustre exposto ao oxigênio, sendo que a maior parte dos organismos isolados pertencia a Desulfovibrio sp. 


\section{CONCLUSÕES}

- A quantidade adicionada de oxigênio (3 - 3,5 mg/L de OD) nos reatores contendo acetato de sódio e etanol não inibiu a metanogênese, de acordo com os valores das velocidades de produção e concentrações de metano observadas. Entretanto, nos reatores contendo lactato e oxigênio, a metanogênese foi severamente inibida, também com base nos valores observados nos reatores controle alimentados com o mesmo substrato.

- A presença do oxigênio nos reatores contendo acetato e etanol não prejudicou a redução de sulfato. Nesses reatores, inclusive, observou-se maior consumo de sulfato, comparando-se com os reatores controle. Ao contrário, nos reatores contendo lactato e oxigênio ocorreu pouco consumo de sulfato.

- Dos três substratos orgânicos utilizados, o lactato de sódio foi o menos favorável para a metanogênese, de acordo com as menores concentrações e velocidades de produção de metano em relação ao acetato e etanol.

- Com base no FISH, organismos pertencentes ao Domínio Archaea foram predominantes nos reatores contendo acetato e etanol, nas condições controle e com oxigênio; e lactato na condição controle. Nos reatores contendo lactato e oxigênio houve predomínio de células pertencentes ao Domínio Bacteria. As BRS estiveram presentes em todas condições estudadas, inclusive na presença de oxigênio.

- Conforme os dados deste trabalho, pode-se concluir que as arquéias metanogênicas e as bactérias redutoras de sulfato podem tolerar a presença de oxigênio no meio, inclusive manter suas atividades metabólicas de produção de metano e redução de sulfato, respectivamente. 


\section{RECOMENDAÇÕES}

- Avaliar, por meio de PCR/DGGE e sequenciamento os microrganismos presentes em reatores submetidos à presença do oxigênio, com ênfase nas populações de BRS e arquéias metanogênicas.

- Utilizar concentrações menores de oxigênio dissolvido, que a usada neste trabalho, em reatores anaeróbios em batelada, com o intuito de avaliar quais grupos de microorganismos prevaleceriam.

- Realizar ensaios sob condições desnitrificantes e sulfetogênicas simultaneamente, com a finalidade de avaliar a utilização do nitrato pelas BRS e evitar a liberação de sulfeto, que é corrosivo e tóxico. 


\section{REFERÊNCIAS BIBLIOGRÁFICAS}

ABE, D. S. Desnitrificação e caracterização filogenética de bactérias de vida livre bactérias aderidas às partículas no hipolímnio do Lago Kizaki, Japão. Tese (Doutorado) - Escola de Engenharia de São Carlos, Universidade de São Paulo, São Carlos, 1998.

AMANN, R. L. et al. Combination of 16S rRNA-target oligonucleotide probes with flow cytometry for analyzing mixed microbial populations. Applied Environmental Microbiology, v. 56, p. 1919-1925, 1990.

APHA, AWWA, WPCF. Standard methods for examination of water and wastewater. American Public Health Association/American Water Works Association/Water Environmental Federation, Washington, 1998.

ARAÚJO, J. C. Biofilmes anaeróbios: desenvolvimento e caracterização filogenética usando a hibridação in situ com sondas fluorescentes. Tese (Doutorado) - Escola de Engenharia de São Carlos, Universidade de São Paulo, São Carlos, 2001.

CANFIELD, D.E; DES MARAIS, D.J. Aerobic sulfate reduction in microbial mats. Science,v. 251, p. 1471-1473, 1991.

CYPIONKA, H. Oxygen respiration by Desulfovibrio species. Annual Reviews of Microbiology, v. 54, p. 827-848, 2000.

DANNEMBERG, S. KRODER, M.; DILLING, W.; CYPIONKA, H. Oxidation of $\mathrm{H}_{2}$, organic compounds and inorganic sulfur compounds coupled to reduction of $\mathrm{O}_{2}$ or nitrate by sulfatereducing bacteria. Archives of Microbiology, v. 158, P. 93-99, 1992.

DÍAZ, E.; AMILS, R.; SANZ, J. L. Molecular ecology of anaerobic granular sludge grown at different conditions. Water Science and Technology, v. 48, n. 6, p. 57-64, 2003. 
DILLING, W.; CYPIONKA, H. Aerobic respiration in sulfate-reducing bacteria. FEMS Microbiology Letters, v. 71, p. 123-128, 1990.

DOMINGUES, M.R. Avaliação da metanogênese e sulfetogênese em reatores anaeróbios em batelada e de leito fixo, sob condições termofílicas. 165 p. Dissertação (Mestrado) - Escola de Engenharia de São Carlos, Universidade de São Paulo, São Carlos, 2001.

ESCHEMANN, A.; KÜHL, M.; CYPIONKA, H. Aerotaxis in Desulfovibrio. Environmental Microbiology, v. 1, n. 6, p. 489-494, 1999.

ESTRADA-VÁZQUEZ， C.; MACARIE， H.; RODRÍGUEZ-VÁZQUEZ， R.; ESPARZAGARCÍA, F.; POGGI-VARALDO, H. M. The effect of the supplementation with a primary carbon source on the resistance to oxygen exposure of methanogenic sludge. Water Science \& Technology, v. 48, n. 6, p. 119-124, 2003.

FARELEIRA, P.; SANTOS, B.S.; ANTÔNIO, C.; MORADAS-FERREIRA, P.; LeGALL, J.; XAVIER, A.V.; SANTOS, H. Response of a strict anaerobe to oxygen: survivel strategies in Desulfovibrio gigas. Microbiology, v. 149, p. 1513-1522, 2003.

GARCIA, J., PATEL, B.K.C., OLLIVIER, B. Taxonomic, phylogenetic and ecological diversity of methanogenic Archaea. Anaerobe, v. 6, p. 205-226, 2000.

HAHN, D.; LUDWIG, W.; AKKERMANS, A. D. L.; SCHLEIFER, K. H. Detection of microorganisms in soil after in situ hybridization with rRNA target, fluorescent labeled oligonucleotides. Journal of General Microbiology, v. 138, p. 879-887, 1992.

HIRASAWA, J.S. Avaliação da comunidade microbiana anaeróbia em reator sulfetogênico utilizando a hibridação in situ com sondas fluorescentes (FISH). 82 p. Dissertação (Mestrado) - Escola de Engenharia de São Carlos, Universidade de São Paulo, São Carlos, 2003. 
HOLMER, M.; STORKHOLM, P. Sulphate reduction and sulphur cycling in lake sediments: a review. Freshwater Biology Special Review, v. 46, p. 431-451, 2001.

JENNEY JUNIOR., F.E.; VERHAGEN, M.F.J.M.; CUI, X.; ADAMS, M.W.W. Anaerobic microbes: oxygen detoxification without superoxide dismutase. Science, v. 286, p. 306-309, 1999.

JOHNSON, M. S.; ZHULIN, I.B.; GAPUZAN, M.E.R.; TAYLOR, B.L. Oxygen-dependent growth of the obligate anaerobe Desulfovibrio vulgaris Hildenborough. Journal of Bacteriology, v. 179, n. 17, p. 5598-5601, 1997.

JONES, W. J.; GUYOT, J.; WOLFE, R. S. Methanogenesis form sucrose by defined immobilized consortia. Applied and Environmental Microbiology, v. 47. n. 1, p. 1-6, 1984.

KATO, M. T.; FIELD, J. A.; LETTINGA, G. Anaerobe tolerance to oxygen and the potentials of anaerobic and aerobic cocultures for wastewater treatment. Brazilian Journal of Chemical $\begin{array}{lllllll}\text { Engineering, } & \text { v. } & 14, & \text { n. } & 4, & 1997 . & \text { Disponível em: }\end{array}$ $<$ http://www.scielo.br/scielo.php?script=sci_arttext\&pid=S0104 66321997000400015\&lng=en\&nrm=iso>. Acesso em: 07 fev 2007. Pré-publicação. doi: 10.1590/S0104-66321997000400015

KJELDSEN, K. U.; JOULIAN, C.; INGVORSEN, K. Oxygen tolerance of sulfate-reducing bacteria in activated sludge. Environmental Science \& Technology, v. 38, p. 2038-2043, 2004.

KREKELER, D.; CYPIONKA, H. The preferred electron acceptor of Desulfovibrio desulfuricans CSN. FEMS Microbiology Ecology, v. 17, p. 271-278, 1995.

KREKELER, D.; SIGALEVICH, P.; TESKE, A.; CYPIONKA, H.; COHEN, Y. A sulfatereducing bacterium from the oxic layer of a microbial mat from Solar Lake (Sinai), Desulfovibrio oxyclinae sp. nov. Archives of Microbiology, v. 167, p. 369-375, 1997. 
KREKELER, D; TESKE, A.; CYPIONKA, H. Strategies of sulfate-reducing bacteria to escape oxygen stress in a cyanobacterial mat. FEMS Microbiology Ecology, v. 25, p. 89-96, 1998.

LENS, P. N.; DE POORTER, M. P.; CRONENBERG, C. C.; VERSTRAETE, W. H. Sulfate reducing and methane producing bacteria in aerobic wastewater treatment systems. Water Research , v. 29, p. 871-880, 1994.

LENS, P.N.L.; VISSER, A.; JANSSEN, A.J.H.; HULSHOFF POL, L.,W.; LETTINGA, G. Biotechnological treatment of sulfate-rich wastewaters. Environmental Science and Technology, v. 28, n. 1, p. 41-88, 1998.

MADIGAN, M.T.; MARTINKO, J.M.; PRKER, J. Brock biology of microorganisms. Tradução de Cynthia Maria Kyaw. New Jersey: Prentice Hall, 1997.

MANZ, W.; AMANN, R.; LUDWIG, W.; WAGNER, M.; SCHLEIFER, K. H. Phylogenetic oligodeoxynucleotide probes for the major subclasses of Proteobacteria: problems and solutions. Systematic and Applied Environmental Microbiology, v. 15, p. 593-600, 1992.

MARSCHALL, C; FRENZEL, P; CYPIONKA, H. Influence of oxygen on sulfate reduction and growth of sulfate-reducing bacteria. Archives of Microbiology, v. 159, p. 168-173, 1993.

MORAES, E. M.; ADORNO, M. A. T.; ZAIAT, M.; FORESTI, E. Determinação de ácidos voláteis por cromatografia gasosa em efluentes de reatores anaeróbios tratando resíduos líquidos e sólidos. In: VI Oficina e Seminário Latino-Americano de Digestão Anaeróbia. Recife: editora Universitária - UFPE, 2000. p. 235-238.

OMIL, F.; OUDE ELFERINK, S. J. W. H.; LENS, P.; HULSHOFF POL, L. W.; LETTINGA, G. Effect of the inoculation with Desulforhabdus amnigenus and $\mathrm{pH}$ or $\mathrm{O}_{2}$ shocks on the competition between sulphate reducing and methanogenic bacteria in an acetate fed UASB reactor. Bioresource Technology, p. 113-122, 1997. 
RASKIN, L.; STROMLEY, J. M.; RITTMANN, B. E.; STAHL, D. A. Group-specific 16S rRNA hybridization probes to describe natural communities of methanogens. Applied and Environmental Microbiology, v. 60, p. 1232-1240, 1994.

SASS, H.; CYPIONKA, H.; BABENZIEN, H. Vertical distribution of sulfate-reducing bacteria at the oxic-anoxic interface in sediments of the oligotrophic Lake Stechlin. FEMS Microbiology Ecology, v. 22, p. 245-255, 1997.

SIGALEVICH, P; COHEN, Y. Oxygen-dependent growth of the sulfate-reducing bacterium Desulfovibrio oxyclinae in coculture with Marinobacter sp. strain MB in an aerated sulfatedepleted chemostat. Applied and Environmental Microbiology, v. 66, n. 11, p. 5019-5023, 2000.

STAHL, D. A.; AMANN, R. I. Development and application of nucleic acid techniques in bacterial systematics. London: John Wiley \& Sons Ltd., p. 207-248, 1991.

TESKE, A. Sulfate-reducing bacteria and their activities in cyanobacterial mats of Solar Lake (Sinai, Egypt). Applied and Environmental Microbiology, v. 64, n. 8, p. 2943-2951, 1998.

VAZZOLER, R. F.; MONTENEGRO, M. A. P.; CALLADO, N.H.; FORESTI, E. Uma proposta para o metabolismo do sulfato em um biodigestor anaeróbio de fluxo ascendente e manta de lodo, operado com glicose, acetato e metanol. In: $11^{\circ}$ Simpósio Nacional de Fermentações, São Carlos, 1996.

WIDDEL, F. Microbiology and ecology of sulfate and sulfur-reducing bacteria. In: ZEHNDER, A. J. B. Biology of anaerobic microorganisms. John Wiley \& Sons Inc., 1988. p. 469-586.

WIDDEL, F.; PFENNING, N. Dissimilatory sulfate or sulfur reducing bacteria. In: BRENNER, D.J.; KRIEG, N.R.; STALEY, J.T. Bergey's Manual of Systematic Bacteriology. Springer. V. 2, 1984. 
YODA, M.; KITAGAWA, M.; MYAJI, Y. Long term competition between sulfate reducing and methane producing bacteria for acetate in anaerobic biofilm. Water Research, v. 21, p. 15471556, 1987.

ZINDER, S.H.; CARDWELL, S.C.; ANGUISH, T.; LEE, M.; KOCH, M. Methanogenesis in a thermophilic $\left(58^{\circ} \mathrm{C}\right)$ anaerobic digestor. Methanotrix sp. as an important aceticlastic methanogen. Applied Environmental Microbiology, v. 47, p. 796-807, 1984.

ZITOMER, D. H. Stoichiometry of combined aerobic and methanogenic COD transformation. Water Research, v. 32, p. 669-676, 1997.

ZITOMER, D. H.; SHROUT, J. D. Feasibility and benefits of methanogenesis under oxygenlimited conditions. Waste Management, v. 18, p. 107-116, 1998. 
APÊNDICE A - Velocidades de consumo de sulfato nos reatores contendo acetato de sódio.

Reatores com Oxigênio

\begin{tabular}{|c|c|c|c|}
\hline Tempo (h) & $\begin{array}{c}\text { Velocidades } \\
\text { (mg/L.h) }\end{array}$ & Tempo (h) & $\begin{array}{c}\text { Velocidades } \\
\text { (mg/L.h) }\end{array}$ \\
\hline 0,00 & $-1,97$ & 517,02 & $-0,73$ \\
\hline 16,68 & $-1,94$ & 533,69 & $-0,71$ \\
\hline 33,36 & $-1,88$ & 550,37 & $-0,68$ \\
\hline 50,03 & $-1,82$ & 567,05 & $-0,66$ \\
\hline 66,71 & $-1,76$ & 583,73 & $-0,64$ \\
\hline 83,39 & $-1,70$ & 600,41 & $-0,62$ \\
\hline 100,07 & $-1,65$ & 617,08 & $-0,60$ \\
\hline 116,75 & $-1,60$ & 633,76 & $-0,58$ \\
\hline 133,42 & $-1,55$ & 650,44 & $-0,56$ \\
\hline 150,10 & $-1,50$ & 667,12 & $-0,54$ \\
\hline 166,78 & $-1,45$ & 683,80 & $-0,53$ \\
\hline 183,46 & $-1,40$ & 700,47 & $-0,51$ \\
\hline 200,14 & $-1,36$ & 717,15 & $-0,49$ \\
\hline 216,81 & $-1,31$ & 733,83 & $-0,48$ \\
\hline 233,49 & $-1,27$ & 750,51 & $-0,46$ \\
\hline 250,17 & $-1,23$ & 767,19 & $-0,45$ \\
\hline 266,85 & $-1,19$ & 783,86 & $-0,43$ \\
\hline 283,53 & $-1,15$ & 800,54 & $-0,42$ \\
\hline 300,20 & $-1,12$ & 817,22 & $-0,41$ \\
\hline 316,88 & $-1,08$ & 833,90 & $-0,39$ \\
\hline 333,56 & $-1,05$ & 850,58 & $-0,38$ \\
\hline 350,24 & $-1,01$ & 867,25 & $-0,37$ \\
\hline 366,92 & $-0,98$ & 883,93 & $-0,36$ \\
\hline 383,59 & $-0,95$ & 900,61 & $-0,35$ \\
\hline 400,27 & $-0,92$ & 917,29 & $-0,33$ \\
\hline 416,95 & $-0,89$ & 933,97 & $-0,32$ \\
\hline 433,63 & $-0,86$ & 950,64 & $-0,31$ \\
\hline 450,31 & $-0,83$ & 967,32 & $-0,30$ \\
\hline 466,98 & $-0,81$ & 984,00 & $-0,30$ \\
\hline 483,66 & $-0,78$ & & \\
\hline 500,34 & $-0,75$ & & \\
\hline
\end{tabular}


Reatores controle

\begin{tabular}{|c|c|c|c|}
\hline Tempo (h) & Velocidades (mg/L.h) & Tempo (h) & Velocidades (mg/L.h) \\
\hline 0,00 & $-1,01$ & 517,02 & $-0,45$ \\
\hline 16,68 & $-1,00$ & 533,69 & $-0,44$ \\
\hline 33,36 & $-0,97$ & 550,37 & $-0,43$ \\
\hline 50,03 & $-0,95$ & 567,05 & $-0,42$ \\
\hline 66,71 & $-0,92$ & 583,73 & $-0,40$ \\
\hline 83,39 & $-0,90$ & 600,41 & $-0,39$ \\
\hline 100,07 & $-0,87$ & 617,08 & $-0,38$ \\
\hline 116,75 & $-0,85$ & 633,76 & $-0,37$ \\
\hline 133,42 & $-0,83$ & 650,44 & $-0,36$ \\
\hline 150,10 & $-0,81$ & 667,12 & $-0,35$ \\
\hline 166,78 & $-0,79$ & 683,80 & $-0,34$ \\
\hline 183,46 & $-0,77$ & 700,47 & $-0,34$ \\
\hline 200,14 & $-0,75$ & 717,15 & $-0,33$ \\
\hline 216,81 & $-0,73$ & 733,83 & $-0,32$ \\
\hline 233,49 & $-0,71$ & 750,51 & $-0,31$ \\
\hline 250,17 & $-0,69$ & 767,19 & $-0,30$ \\
\hline 266,85 & $-0,67$ & 783,86 & $-0,29$ \\
\hline 283,53 & $-0,65$ & 800,54 & $-0,29$ \\
\hline 300,20 & $-0,64$ & 817,22 & $-0,28$ \\
\hline 316,88 & $-0,62$ & 833,90 & $-0,27$ \\
\hline 333,56 & $-0,60$ & 850,58 & $-0,26$ \\
\hline 350,24 & $-0,59$ & 867,25 & $-0,26$ \\
\hline 366,92 & $-0,57$ & 883,93 & $-0,25$ \\
\hline 383,59 & $-0,56$ & 900,61 & $-0,24$ \\
\hline 400,27 & $-0,54$ & 917,29 & $-0,24$ \\
\hline 416,95 & $-0,53$ & 933,97 & $-0,23$ \\
\hline 433,63 & $-0,51$ & 950,64 & $-0,23$ \\
\hline 450,31 & $-0,50$ & 967,32 & $-0,22$ \\
\hline 466,98 & $-0,49$ & 984,00 & $-0,22$ \\
\hline 483,66 & $-0,47$ & & \\
\hline 500,34 & $-0,46$ & & \\
\hline
\end{tabular}


APÊNDICE B - Velocidades de consumo de sulfato nos reatores contendo etanol.

\section{Reatores com oxigênio}

\begin{tabular}{|c|c|c|c|}
\hline Tempo (h) & $\begin{array}{c}\text { Velocidades } \\
\text { (mg/L.h) }\end{array}$ & Tempo (h) & $\begin{array}{c}\text { Velocidades } \\
\text { (mg/L.h) }\end{array}$ \\
\hline 0,00 & $-2,65$ & 353,08 & $-0,70$ \\
\hline 11,39 & $-2,59$ & 364,47 & $-0,67$ \\
\hline 22,78 & $-2,48$ & 375,86 & $-0,64$ \\
\hline 34,17 & $-2,37$ & 387,25 & $-0,62$ \\
\hline 45,56 & $-2,27$ & 398,64 & $-0,59$ \\
\hline 56,95 & $-2,18$ & 410,03 & $-0,56$ \\
\hline 68,34 & $-2,08$ & 421,42 & $-0,54$ \\
\hline 79,73 & $-1,99$ & 432,81 & $-0,52$ \\
\hline 91,12 & $-1,91$ & 444,20 & $-0,50$ \\
\hline 102,51 & $-1,83$ & 455,59 & $-0,47$ \\
\hline 113,90 & $-1,75$ & 466,98 & $-0,45$ \\
\hline 125,29 & $-1,68$ & 478,37 & $-0,44$ \\
\hline 136,68 & $-1,60$ & 489,76 & $-0,42$ \\
\hline 148,07 & $-1,54$ & 501,15 & $-0,40$ \\
\hline 159,46 & $-1,47$ & 512,54 & $-0,38$ \\
\hline 170,85 & $-1,41$ & 523,93 & $-0,37$ \\
\hline 182,24 & $-1,35$ & 535,32 & $-0,35$ \\
\hline 193,63 & $-1,29$ & 546,71 & $-0,34$ \\
\hline 205,02 & $-1,24$ & 558,10 & $-0,32$ \\
\hline 216,41 & $-1,18$ & 569,49 & $-0,31$ \\
\hline 227,80 & $-1,13$ & 580,88 & $-0,29$ \\
\hline 239,19 & $-1,08$ & 592,27 & $-0,28$ \\
\hline 250,58 & $-1,04$ & 603,66 & $-0,27$ \\
\hline 261,97 & $-0,99$ & 615,05 & $-0,26$ \\
\hline 273,36 & $-0,95$ & 626,44 & $-0,25$ \\
\hline 284,75 & $-0,91$ & 637,83 & $-0,24$ \\
\hline 296,14 & $-0,87$ & 649,22 & $-0,23$ \\
\hline 307,53 & $-0,84$ & 660,61 & $-0,22$ \\
\hline 318,92 & $-0,80$ & 672,00 & $-0,21$ \\
\hline 330,31 & $-0,77$ & & \\
\hline 341,69 & $-0,73$ & & \\
\hline
\end{tabular}


Reatores controle

\begin{tabular}{|c|c|c|c|}
\hline Tempo (h) & Velocidades (mg/L.h) & Tempo (h) & Velocidades (mg/L.h) \\
\hline 0,00 & $-2,10$ & 353,08 & $-0,51$ \\
\hline 11,39 & $-2,05$ & 364,47 & $-0,49$ \\
\hline 22,78 & $-1,96$ & 375,86 & $-0,47$ \\
\hline 34,17 & $-1,87$ & 387,25 & $-0,45$ \\
\hline 45,56 & $-1,79$ & 398,64 & $-0,43$ \\
\hline 56,95 & $-1,71$ & 410,03 & $-0,41$ \\
\hline 68,34 & $-1,63$ & 421,42 & $-0,39$ \\
\hline 79,73 & $-1,56$ & 432,81 & $-0,37$ \\
\hline 91,12 & $-1,49$ & 444,20 & $-0,35$ \\
\hline 102,51 & $-1,42$ & 455,59 & $-0,34$ \\
\hline 113,90 & $-1,35$ & 466,98 & $-0,32$ \\
\hline 125,29 & $-1,29$ & 478,37 & $-0,31$ \\
\hline 136,68 & $-1,23$ & 489,76 & $-0,29$ \\
\hline 148,07 & $-1,18$ & 501,15 & $-0,28$ \\
\hline 159,46 & $-1,12$ & 512,54 & $-0,27$ \\
\hline 170,85 & $-1,07$ & 523,93 & $-0,26$ \\
\hline 182,24 & $-1,03$ & 535,32 & $-0,24$ \\
\hline 193,63 & $-0,98$ & 546,71 & $-0,23$ \\
\hline 205,02 & $-0,93$ & 558,10 & $-0,22$ \\
\hline 216,41 & $-0,89$ & 569,49 & $-0,21$ \\
\hline 227,80 & $-0,85$ & 580,88 & $-0,20$ \\
\hline 239,19 & $-0,81$ & 592,27 & $-0,19$ \\
\hline 250,58 & $-0,78$ & 603,66 & $-0,18$ \\
\hline 261,97 & $-0,74$ & 615,05 & $-0,18$ \\
\hline 273,36 & $-0,71$ & 626,44 & $-0,17$ \\
\hline 284,75 & $-0,68$ & 637,83 & $-0,16$ \\
\hline 296,14 & $-0,65$ & 649,22 & $-0,15$ \\
\hline 307,53 & $-0,62$ & 660,61 & $-0,15$ \\
\hline 318,92 & $-0,59$ & 672,00 & $-0,14$ \\
\hline 330,31 & $-0,56$ & & \\
\hline 341,69 & $-0,54$ & & \\
\hline
\end{tabular}


APÊNDICE C - Velocidades de consumo de sulfato nos reatores contendo lactato de sódio.

\section{Reatores com oxigênio}

\begin{tabular}{|c|c|c|c|}
\hline Tempo (h) & Velocidades (mg/L.h) & Tempo (h) & Velocidades (mg/L.h) \\
\hline 0,00 & $-1,08$ & 340,47 & $-0,39$ \\
\hline 10,98 & $-1,06$ & 351,46 & $-0,38$ \\
\hline 21,97 & $-1,02$ & 362,44 & $-0,36$ \\
\hline 32,95 & $-0,99$ & 373,42 & $-0,35$ \\
\hline 43,93 & $-0,96$ & 384,41 & $-0,34$ \\
\hline 54,92 & $-0,93$ & 395,39 & $-0,33$ \\
\hline 65,90 & $-0,90$ & 406,37 & $-0,32$ \\
\hline 76,88 & $-0,87$ & 417,36 & $-0,31$ \\
\hline 87,86 & $-0,84$ & 428,34 & $-0,30$ \\
\hline 98,85 & $-0,81$ & 439,32 & $-0,29$ \\
\hline 109,83 & $-0,78$ & 450,31 & $-0,28$ \\
\hline 120,81 & $-0,76$ & 461,29 & $-0,27$ \\
\hline 131,80 & $-0,73$ & 472,27 & $-0,26$ \\
\hline 142,78 & $-0,71$ & 483,25 & $-0,25$ \\
\hline 153,76 & $-0,69$ & 494,24 & $-0,24$ \\
\hline 164,75 & $-0,66$ & 505,22 & $-0,24$ \\
\hline 175,73 & $-0,64$ & 516,20 & $-0,23$ \\
\hline 186,71 & $-0,62$ & 527,19 & $-0,22$ \\
\hline 197,69 & $-0,60$ & 538,17 & $-0,21$ \\
\hline 208,68 & $-0,58$ & 549,15 & $-0,21$ \\
\hline 219,66 & $-0,56$ & 560,14 & $-0,20$ \\
\hline 230,64 & $-0,54$ & 571,12 & $-0,19$ \\
\hline 241,63 & $-0,52$ & 582,10 & $-0,19$ \\
\hline 252,61 & $-0,51$ & 593,08 & $-0,18$ \\
\hline 263,59 & $-0,49$ & 604,07 & $-0,17$ \\
\hline 274,58 & $-0,47$ & 615,05 & $-0,17$ \\
\hline 285,56 & $-0,46$ & 626,03 & $-0,16$ \\
\hline 296,54 & $-0,44$ & 637,02 & $-0,16$ \\
\hline 307,53 & $-0,43$ & 648,00 & $-0,15$ \\
\hline 318,51 & $-0,42$ & & \\
\hline 329,49 & $-0,40$ & & \\
\hline
\end{tabular}


Reatores controle

\begin{tabular}{|c|c|c|c|}
\hline Tempo (h) & Velocidades (mg/L.h) & Tempo (h) & Velocidades (mg/L.h) \\
\hline 0,00 & $-7,87$ & 340,47 & $-0,15$ \\
\hline 10,98 & $-7,39$ & 351,46 & $-0,13$ \\
\hline 21,97 & $-6,49$ & 362,44 & $-0,11$ \\
\hline 32,95 & $-5,70$ & 373,42 & $-0,10$ \\
\hline 43,93 & $-5,00$ & 384,41 & $-0,09$ \\
\hline 54,92 & $-4,39$ & 395,39 & $-0,08$ \\
\hline 65,90 & $-3,85$ & 406,37 & $-0,07$ \\
\hline 76,88 & $-3,38$ & 417,36 & $-0,06$ \\
\hline 87,86 & $-2,97$ & 428,34 & $-0,05$ \\
\hline 98,85 & $-2,61$ & 439,32 & $-0,05$ \\
\hline 109,83 & $-2,29$ & 450,31 & $-0,04$ \\
\hline 120,81 & $-2,01$ & 461,29 & $-0,04$ \\
\hline 131,80 & $-1,76$ & 472,27 & $-0,03$ \\
\hline 142,78 & $-1,55$ & 483,25 & $-0,03$ \\
\hline 153,76 & $-1,36$ & 494,24 & $-0,02$ \\
\hline 164,75 & $-1,19$ & 505,22 & $-0,02$ \\
\hline 175,73 & $-1,05$ & 516,20 & $-0,02$ \\
\hline 186,71 & $-0,92$ & 527,19 & $-0,02$ \\
\hline 197,69 & $-0,81$ & 538,17 & $-0,01$ \\
\hline 208,68 & $-0,71$ & 549,15 & $-0,01$ \\
\hline 219,66 & $-0,62$ & 560,14 & $-0,01$ \\
\hline 230,64 & $-0,55$ & 571,12 & $-0,01$ \\
\hline 241,63 & $-0,48$ & 582,10 & $-0,01$ \\
\hline 252,61 & $-0,42$ & 593,08 & $-0,01$ \\
\hline 263,59 & $-0,37$ & 604,07 & $-0,01$ \\
\hline 274,58 & $-0,32$ & 615,05 & $-0,01$ \\
\hline 285,56 & $-0,28$ & 626,03 & $-0,01$ \\
\hline 296,54 & $-0,25$ & 637,02 & 0,00 \\
\hline 307,53 & $-0,22$ & 648,00 & 0,00 \\
\hline 318,51 & $-0,19$ & & \\
\hline 329,49 & $-0,17$ & & \\
\hline
\end{tabular}


APÊNDICE D - Velocidades de produção de metano reatores contendo acetato de sódio.

\section{Reatores com oxigênio}

\begin{tabular}{|c|c|c|c|}
\hline Tempo (h) & $\begin{array}{c}\text { Velocidades } \\
\text { (mg/L.h) }\end{array}$ & Tempo (h) & $\begin{array}{c}\text { Velocidades } \\
\text { (mg/L.h) }\end{array}$ \\
\hline 0,00 & 0,0343 & 246,16 & 0,0000 \\
\hline 7,94 & 0,0440 & 254,10 & 0,0000 \\
\hline 15,88 & 0,0680 & 262,04 & 0,0000 \\
\hline 23,82 & 0,1017 & 269,98 & 0,0000 \\
\hline 31,76 & 0,1454 & 277,92 & 0,0000 \\
\hline 39,70 & 0,1946 & 285,86 & 0,0000 \\
\hline 47,64 & 0,2394 & 293,81 & 0,0000 \\
\hline 55,58 & 0,2661 & 301,75 & 0,0000 \\
\hline 63,53 & 0,2645 & 309,69 & 0,0000 \\
\hline 71,47 & 0,2354 & 317,63 & 0,0000 \\
\hline 79,41 & 0,1895 & 325,57 & 0,0000 \\
\hline 87,35 & 0,1405 & 333,51 & 0,0000 \\
\hline 95,29 & 0,0978 & 341,45 & 0,0000 \\
\hline 103,23 & 0,0651 & 349,39 & 0,0000 \\
\hline 111,17 & 0,0420 & 357,33 & 0,0000 \\
\hline 119,11 & 0,0266 & 365,27 & 0,0000 \\
\hline 127,05 & 0,0166 & 373,21 & 0,0000 \\
\hline 134,99 & 0,0103 & 381,15 & 0,0000 \\
\hline 142,93 & 0,0064 & 389,09 & 0,0000 \\
\hline 150,87 & 0,0039 & 397,03 & 0,0000 \\
\hline 158,81 & 0,0024 & 404,97 & 0,0000 \\
\hline 166,75 & 0,0015 & 412,92 & 0,0000 \\
\hline 174,69 & 0,0009 & 420,86 & 0,0000 \\
\hline 182,64 & 0,0006 & 428,80 & 0,0000 \\
\hline 190,58 & 0,0003 & 436,74 & 0,0000 \\
\hline 198,52 & 0,0002 & 444,68 & 0,0000 \\
\hline 206,46 & 0,0001 & 452,62 & 0,0000 \\
\hline 214,40 & 0,0001 & 460,56 & 0,0000 \\
\hline 222,34 & 0,0000 & 468,50 & 0,0000 \\
\hline 230,28 & 0,0000 & & \\
\hline 238,22 & 0,0000 & & \\
\hline
\end{tabular}


Reatores controle

\begin{tabular}{|c|c|c|c|}
\hline Tempo (h) & Velocidades (mg/L.h) & Tempo (h) & Velocidades (mg/L.h) \\
\hline 0,00 & 0,0492 & 172,60 & 0,0004 \\
\hline 5,57 & 0,0588 & 178,17 & 0,0003 \\
\hline 11,14 & 0,0811 & 183,74 & 0,0002 \\
\hline 16,70 & 0,1097 & 189,31 & 0,0001 \\
\hline 22,27 & 0,1448 & 194,87 & 0,0001 \\
\hline 27,84 & 0,1850 & 200,44 & 0,0001 \\
\hline 33,41 & 0,2266 & 206,01 & 0,0000 \\
\hline 38,97 & 0,2640 & 211,58 & 0,0000 \\
\hline 44,54 & 0,2902 & 217,14 & 0,0000 \\
\hline 50,11 & 0,2995 & 222,71 & 0,0000 \\
\hline 55,68 & 0,2895 & 228,28 & 0,0000 \\
\hline 61,25 & 0,2627 & 233,85 & 0,0000 \\
\hline 66,81 & 0,2251 & 239,42 & 0,0000 \\
\hline 72,38 & 0,1834 & 244,98 & 0,0000 \\
\hline 77,95 & 0,1434 & 250,55 & 0,0000 \\
\hline 83,52 & 0,1085 & 256,12 & 0,0000 \\
\hline 89,08 & 0,0801 & 261,69 & 0,0000 \\
\hline 94,65 & 0,0581 & 267,25 & 0,0000 \\
\hline 100,22 & 0,0415 & 272,82 & 0,0000 \\
\hline 105,79 & 0,0294 & 278,39 & 0,0000 \\
\hline 111,36 & 0,0207 & 283,96 & 0,0000 \\
\hline 116,92 & 0,0145 & 289,53 & 0,0000 \\
\hline 122,49 & 0,0101 & 295,09 & 0,0000 \\
\hline 128,06 & 0,0070 & 300,66 & 0,0000 \\
\hline 133,63 & 0,0049 & 306,23 & 0,0000 \\
\hline 139,19 & 0,0034 & 311,80 & 0,0000 \\
\hline 144,76 & 0,0023 & 317,36 & 0,0000 \\
\hline 150,33 & 0,0016 & 322,93 & 0,0000 \\
\hline 155,90 & 0,0011 & 328,50 & 0,0000 \\
\hline 161,47 & 0,0008 & & \\
\hline 167,03 & 0,0005 & & \\
\hline
\end{tabular}


APÊNDICE E - Velocidades de produção de metano nos reatores contendo etanol.

\section{Reatores com oxigênio}

\begin{tabular}{|c|c|c|c|}
\hline Tempo (h) & Velocidades (mg/L.h) & Tempo (h) & Velocidades (mg/L.h) \\
\hline 0,00 & 0,0722 & 260,08 & 0,0000 \\
\hline 8,39 & 0,1375 & 268,47 & 0,0000 \\
\hline 16,78 & 0,2982 & 276,86 & 0,0000 \\
\hline 25,17 & 0,4009 & 285,25 & 0,0000 \\
\hline 33,56 & 0,3154 & 293,64 & 0,0000 \\
\hline 41,95 & 0,1520 & 302,03 & 0,0000 \\
\hline 50,34 & 0,0533 & 310,42 & 0,0000 \\
\hline 58,73 & 0,0163 & 318,81 & 0,0000 \\
\hline 67,12 & 0,0048 & 327,20 & 0,0000 \\
\hline 75,51 & 0,0014 & 335,59 & 0,0000 \\
\hline 83,90 & 0,0004 & 343,98 & 0,0000 \\
\hline 92,29 & 0,0001 & 352,37 & 0,0000 \\
\hline 100,68 & 0,0000 & 360,76 & 0,0000 \\
\hline 109,07 & 0,0000 & 369,15 & 0,0000 \\
\hline 117,46 & 0,0000 & 377,54 & 0,0000 \\
\hline 125,85 & 0,0000 & 385,93 & 0,0000 \\
\hline 134,24 & 0,0000 & 394,32 & 0,0000 \\
\hline 142,63 & 0,0000 & 402,71 & 0,0000 \\
\hline 151,02 & 0,0000 & 411,10 & 0,0000 \\
\hline 159,41 & 0,0000 & 419,49 & 0,0000 \\
\hline 167,80 & 0,0000 & 427,88 & 0,0000 \\
\hline 176,19 & 0,0000 & 436,27 & 0,0000 \\
\hline 184,58 & 0,0000 & 444,66 & 0,0000 \\
\hline 192,97 & 0,0000 & 453,05 & 0,0000 \\
\hline 201,36 & 0,0000 & 461,44 & 0,0000 \\
\hline 209,75 & 0,0000 & 469,83 & 0,0000 \\
\hline 218,14 & 0,0000 & 478,22 & 0,0000 \\
\hline 226,53 & 0,0000 & 486,61 & 0,0000 \\
\hline 234,92 & 0,0000 & 495,00 & 0,0000 \\
\hline 243,31 & 0,0000 & & \\
\hline 251,69 & 0,0000 & & \\
\hline
\end{tabular}


Reatores controle

\begin{tabular}{|c|c|c|c|}
\hline Tempo (h) & Velocidades (mg/L.h) & Tempo (h) & Velocidades (mg/L.h) \\
\hline 0,00 & 0,1052 & 184,42 & 0,0000 \\
\hline 5,95 & 0,1485 & 190,37 & 0,0000 \\
\hline 11,90 & 0,2499 & 196,32 & 0,0000 \\
\hline 17,85 & 0,3570 & 202,27 & 0,0000 \\
\hline 23,80 & 0,4111 & 208,22 & 0,0000 \\
\hline 29,75 & 0,3728 & 214,17 & 0,0000 \\
\hline 35,69 & 0,2706 & 220,12 & 0,0000 \\
\hline 41,64 & 0,1650 & 226,07 & 0,0000 \\
\hline 47,59 & 0,0897 & 232,02 & 0,0000 \\
\hline 53,54 & 0,0456 & 237,97 & 0,0000 \\
\hline 59,49 & 0,0224 & 243,92 & 0,0000 \\
\hline 65,44 & 0,0108 & 249,86 & 0,0000 \\
\hline 71,39 & 0,0052 & 255,81 & 0,0000 \\
\hline 77,34 & 0,0025 & 261,76 & 0,0000 \\
\hline 83,29 & 0,0012 & 267,71 & 0,0000 \\
\hline 89,24 & 0,0006 & 273,66 & 0,0000 \\
\hline 95,19 & 0,0003 & 279,61 & 0,0000 \\
\hline 101,14 & 0,0001 & 285,56 & 0,0000 \\
\hline 107,08 & 0,0001 & 291,51 & 0,0000 \\
\hline 113,03 & 0,0000 & 297,46 & 0,0000 \\
\hline 118,98 & 0,0000 & 303,41 & 0,0000 \\
\hline 124,93 & 0,0000 & 309,36 & 0,0000 \\
\hline 130,88 & 0,0000 & 315,31 & 0,0000 \\
\hline 136,83 & 0,0000 & 321,25 & 0,0000 \\
\hline 142,78 & 0,0000 & 327,20 & 0,0000 \\
\hline 148,73 & 0,0000 & 333,15 & 0,0000 \\
\hline 154,68 & 0,0000 & 339,10 & 0,0000 \\
\hline 160,63 & 0,0000 & 345,05 & 0,0000 \\
\hline 166,58 & 0,0000 & 351,00 & 0,0000 \\
\hline 172,53 & 0,0000 & & \\
\hline 178,47 & 0,0000 & & \\
\hline
\end{tabular}


APÊNDICE F - Velocidades de produção de metano nos reatores contendo lactato de sódio.

Reatores com oxigênio

\begin{tabular}{|c|c|c|c|}
\hline Tempo (h) & Velocidades (mg/L.h) & Tempo (h) & Velocidades (mg/L.h) \\
\hline 0,00 & 0,0009 & 110,34 & 0,0002 \\
\hline 3,56 & 0,0012 & 113,90 & 0,0002 \\
\hline 7,12 & 0,0018 & 117,46 & 0,0001 \\
\hline 10,68 & 0,0027 & 121,02 & 0,0001 \\
\hline 14,24 & 0,0042 & 124,58 & 0,0000 \\
\hline 17,80 & 0,0064 & 128,14 & 0,0000 \\
\hline 21,36 & 0,0096 & 131,69 & 0,0000 \\
\hline 24,92 & 0,0143 & 135,25 & 0,0000 \\
\hline 28,47 & 0,0210 & 138,81 & 0,0000 \\
\hline 32,03 & 0,0301 & 142,37 & 0,0000 \\
\hline 35,59 & 0,0417 & 145,93 & 0,0000 \\
\hline 39,15 & 0,0551 & 149,49 & 0,0000 \\
\hline 42,71 & 0,0685 & 153,05 & 0,0000 \\
\hline 46,27 & 0,0792 & 156,61 & 0,0000 \\
\hline 49,83 & 0,0841 & 160,17 & 0,0000 \\
\hline 53,39 & 0,0818 & 163,73 & 0,0000 \\
\hline 56,95 & 0,0729 & 167,29 & 0,0000 \\
\hline 60,51 & 0,0600 & 170,85 & 0,0000 \\
\hline 64,07 & 0,0463 & 174,41 & 0,0000 \\
\hline 67,63 & 0,0340 & 177,97 & 0,0000 \\
\hline 71,19 & 0,0240 & 181,53 & 0,0000 \\
\hline 74,75 & 0,0165 & 185,08 & 0,0000 \\
\hline 78,31 & 0,0111 & 188,64 & 0,0000 \\
\hline 81,86 & 0,0074 & 192,20 & 0,0000 \\
\hline 85,42 & 0,0049 & 195,76 & 0,0000 \\
\hline 88,98 & 0,0032 & 199,32 & 0,0000 \\
\hline 92,54 & 0,0021 & 202,88 & 0,0000 \\
\hline 96,10 & 0,0014 & 206,44 & 0,0000 \\
\hline 99,66 & 0,0009 & 210,00 & 0,0000 \\
\hline 103,22 & 0,0006 & & \\
\hline 106,78 & 0,0004 & & \\
\hline
\end{tabular}


Reatores controle

\begin{tabular}{|c|c|c|c|}
\hline Tempo (h) & Velocidades (mg/L.h) & Tempo (h) & Velocidades (mg/L.h) \\
\hline 0,00 & 0,0297 & 172,86 & 0,0010 \\
\hline 5,58 & 0,0345 & 178,44 & 0,0007 \\
\hline 11,15 & 0,0452 & 184,02 & 0,0005 \\
\hline 16,73 & 0,0585 & 189,59 & 0,0004 \\
\hline 22,31 & 0,0744 & 195,17 & 0,0003 \\
\hline 27,88 & 0,0924 & 200,75 & 0,0002 \\
\hline 33,46 & 0,1117 & 206,32 & 0,0002 \\
\hline 39,03 & 0,1307 & 211,90 & 0,0001 \\
\hline 44,61 & 0,1471 & 217,47 & 0,0001 \\
\hline 50,19 & 0,1587 & 223,05 & 0,0001 \\
\hline 55,76 & 0,1634 & 228,63 & 0,0000 \\
\hline 61,34 & 0,1604 & 234,20 & 0,0000 \\
\hline 66,92 & 0,1504 & 239,78 & 0,0000 \\
\hline 72,49 & 0,1349 & 245,36 & 0,0000 \\
\hline 78,07 & 0,1163 & 250,93 & 0,0000 \\
\hline 83,64 & 0,0969 & 256,51 & 0,0000 \\
\hline 89,22 & 0,0785 & 262,08 & 0,0000 \\
\hline 94,80 & 0,0620 & 267,66 & 0,0000 \\
\hline 100,37 & 0,0481 & 273,24 & 0,0000 \\
\hline 105,95 & 0,0368 & 278,81 & 0,0000 \\
\hline 111,53 & 0,0279 & 284,39 & 0,0000 \\
\hline 117,10 & 0,0209 & 289,97 & 0,0000 \\
\hline 122,68 & 0,0156 & 295,54 & 0,0000 \\
\hline 128,25 & 0,0115 & 301,12 & 0,0000 \\
\hline 133,83 & 0,0085 & 306,69 & 0,0000 \\
\hline 139,41 & 0,0063 & 312,27 & 0,0000 \\
\hline 144,98 & 0,0046 & 317,85 & 0,0000 \\
\hline 150,56 & 0,0034 & 323,42 & 0,0000 \\
\hline 156,14 & 0,0025 & 329,00 & 0,0000 \\
\hline 161,71 & 0,0018 & & \\
\hline 167,29 & 0,0013 & & \\
\hline
\end{tabular}


APÊNDICE G - Concentrações de metano produzidas nos reatores contendo acetato se sódio (triplicata).

\begin{tabular}{|c|c|c|c|c|c|c|c|}
\hline \multirow{3}{*}{$\begin{array}{c}\text { Tempo } \\
\text { acumulado } \\
\text { (h) }\end{array}$} & \multirow{2}{*}{\multicolumn{3}{|c|}{$\begin{array}{c}\text { Concentração de metano }(\mathrm{mmol} / \mathrm{L}) \\
\text { Reatores Acetato/controle }\end{array}$}} & \multirow{3}{*}{$\begin{array}{c}\text { Tempo } \\
\text { acumulado } \\
\text { (h) }\end{array}$} & \multirow{2}{*}{\multicolumn{3}{|c|}{$\begin{array}{c}\text { Concentração de metano }(\mathrm{mmol} / \mathrm{L}) \\
\text { Reatores Acetato/oxigênio }\end{array}$}} \\
\hline & & & & & & & \\
\hline & Reator 1 & Reator 2 & Reator 3 & & Reator 1 & Reator 2 & Reator 3 \\
\hline 0,00 & $-0,2643$ & $-0,2590$ & $-0,2494$ & 0,00 & $-0,4079$ & $-0,3631$ & $-0,3616$ \\
\hline 5,00 & 0,0687 & 0,1082 & 0,1300 & 9,50 & $-0,1305$ & $-0,0613$ & $-0,1035$ \\
\hline 14,50 & 0,5901 & 0,6808 & 0,8201 & 15,00 & 0,1976 & 0,2149 & 0,1631 \\
\hline 20,00 & 1,0912 & 1,2864 & 2,1228 & 22,00 & 0,7032 & 0,5845 & 0,5281 \\
\hline 27,00 & 1,5483 & 1,5373 & 2,9647 & 35,50 & 3,5398 & 2,8795 & 2,9069 \\
\hline 40,50 & 5,0844 & 4,6477 & 7,7476 & 42,00 & 4,2696 & 3,5228 & 3,5127 \\
\hline 47,00 & 5,9338 & 5,5483 & 8,6888 & 48,50 & 7,2168 & 5,9659 & 6,0736 \\
\hline 53,50 & 9,4488 & 8,7891 & 13,1671 & 60,50 & 9,1848 & 7,7061 & 7,7541 \\
\hline 65,50 & 11,8084 & 10,5852 & 14,8890 & 68,00 & 10,5352 & 8,9629 & 9,0553 \\
\hline 73,00 & 13,1704 & 12,5245 & 15,2551 & 84,50 & 16,1691 & 13,9924 & 14,4001 \\
\hline 89,50 & 17,1076 & 16,6388 & 16,9727 & 108,50 & 15,9058 & 15,9228 & 16,0073 \\
\hline 113,00 & 16,0055 & 15,5270 & 15,9047 & 132,00 & 18,9053 & 18,7461 & 19,2268 \\
\hline 137,00 & 18,6052 & 18,7337 & 18,6762 & 155,50 & 18,7603 & 18,2126 & 18,5665 \\
\hline 160,50 & 18,0608 & 17,9810 & 18,7013 & 180,00 & 17,2922 & 17,5035 & 17,3886 \\
\hline 185,00 & 17,3154 & 16,7908 & 17,1334 & 204,00 & 17,6006 & 17,7799 & 17,6018 \\
\hline 209,00 & 17,2501 & 17,1310 & 17,3459 & 277,00 & 16,6485 & 16,0968 & 16,0937 \\
\hline 282,00 & 18,3788 & 18,0909 & 19,2857 & 300,00 & 15,7291 & 16,0060 & 16,7972 \\
\hline 328,50 & 16,5579 & 16,4598 & 15,5927 & 323,50 & 16,3640 & 16,6243 & 15,5406 \\
\hline 448,50 & 19,2280 & 19,2792 & 17,0907 & 468,50 & 15,1983 & 15,5178 & 18,0130 \\
\hline 473,50 & 15,7879 & 15,5974 & 17,0492 & 541,00 & 18,0590 & 18,3670 & 17,9867 \\
\hline 546,00 & 17,8754 & 17,6333 & 18,4880 & 612,00 & 17,5955 & 18,1647 & 19,2036 \\
\hline 617,00 & 17,9278 & 17,7224 & 15,6135 & 659,50 & 18,8181 & 19,1776 & 16,5243 \\
\hline 664,50 & 19,1809 & 19,2914 & 12,4094 & 707,50 & 16,1878 & 16,3707 & 13,2946 \\
\hline 712,50 & 16,6425 & 16,4076 & & 780,00 & 12,8598 & 12,5606 & 14,3886 \\
\hline 785,00 & 13,8869 & 13,8068 & & 828,00 & 14,1961 & 13,9673 & 15,9323 \\
\hline
\end{tabular}


APÊNDICE H - Concentrações de metano produzidas nos reatores contendo etanol (triplicata).

\begin{tabular}{|c|c|c|c|c|c|c|c|}
\hline \multirow{3}{*}{$\begin{array}{c}\text { Tempo } \\
\text { acumulado } \\
\text { (h) }\end{array}$} & \multirow{2}{*}{\multicolumn{3}{|c|}{$\begin{array}{c}\text { Concentração de metano }(\mathrm{mmol} / \mathrm{L}) \\
\text { Reatores Etanol/controle }\end{array}$}} & \multirow{3}{*}{$\begin{array}{c}\text { Tempo } \\
\text { acumulado } \\
\text { (h) }\end{array}$} & \multirow{2}{*}{\multicolumn{3}{|c|}{$\begin{array}{c}\text { Concentração de metano }(\mathrm{mmol} / \mathrm{L}) \\
\text { Reatores Etanol/oxigênio }\end{array}$}} \\
\hline & & & & & & & \\
\hline & Reator 1 & Reator 2 & Reator 3 & & Reator 1 & Reator 2 & Reator 3 \\
\hline 0,00 & 0,4215 & 0,3864 & 0,3074 & 0,00 & $-0,2984$ & 0,0897 & $-0,1503$ \\
\hline 4,50 & 1,3651 & 1,1647 & 1,1246 & 4,50 & $-0,0961$ & 0,8769 & 0,0166 \\
\hline 13,00 & 3,3341 & 2,7520 & 3,0289 & 13,00 & 0,3000 & 2,6576 & 0,7332 \\
\hline 20,50 & 5,3889 & 4,7032 & 5,0513 & 20,50 & 0,9912 & 5,2956 & 2,1356 \\
\hline 26,50 & 8,1129 & 7,7095 & 7,3459 & 26,50 & 2,3038 & 8,8134 & 4,4959 \\
\hline 39,50 & 12,7531 & 11,4770 & 12,2279 & 39,50 & 5,3274 & 11,3413 & 10,1073 \\
\hline 63,50 & 13,2954 & 13,9327 & 14,6458 & 63,50 & 13,0081 & 13,0388 & 12,4463 \\
\hline 87,50 & 13,6950 & 12,5018 & 7,1067 & 87,50 & 7,7367 & 11,5777 & 11,9989 \\
\hline 185,00 & 13,5046 & 12,0634 & 11,0849 & 135,00 & 14,0933 & 11,1455 & 12,2644 \\
\hline 231,50 & 14,0918 & 12,8840 & 14,2402 & 185,00 & 9,9060 & 11,6788 & 12,3839 \\
\hline 305,00 & 14,8276 & 13,3779 & 14,3455 & 231,50 & 16,4401 & 12,5372 & 13,3133 \\
\hline \multirow[t]{2}{*}{351,00} & 14,2470 & 14,1540 & 15,1264 & 305,00 & 17,9069 & 12,3686 & 13,0388 \\
\hline & & & & 351,00 & 17,4148 & 11,4985 & 12,2517 \\
\hline
\end{tabular}


APÊNDICE I - Concentração de metano produzida nos reatores contendo lactato de sódio (triplicata).

\begin{tabular}{|c|c|c|c|c|c|c|c|}
\hline \multirow{3}{*}{$\begin{array}{c}\text { Tempo } \\
\text { acumulado } \\
\text { (h) }\end{array}$} & \multirow{2}{*}{\multicolumn{3}{|c|}{$\begin{array}{c}\text { Concentração de metano }(\mathrm{mmol} / \mathrm{L}) \\
\text { Reatores Lactato/controle }\end{array}$}} & \multirow{3}{*}{$\begin{array}{c}\text { Tempo } \\
\text { acumulado } \\
\text { (h) }\end{array}$} & \multirow{2}{*}{\multicolumn{3}{|c|}{$\begin{array}{c}\text { Concentração de metano }(\mathrm{mmol} / \mathrm{L}) \\
\text { Reatores Lactato/oxigênio }\end{array}$}} \\
\hline & & & & & & & \\
\hline & Reator 1 & Reator 2 & Reator 3 & & Reator 1 & Reator 2 & Reator 3 \\
\hline 0,00 & $-0,3423$ & $-0,3024$ & $-0,2975$ & 0,00 & $-0,4052$ & $-0,4067$ & $-0,3960$ \\
\hline 6,50 & $-0,2280$ & $-0,1645$ & $-0,1543$ & 6,50 & $-0,4339$ & $-0,4207$ & $-0,4068$ \\
\hline 15,00 & 0,0495 & 0,2533 & 0,4388 & 15,00 & $-0,3918$ & $-0,3872$ & $-0,3936$ \\
\hline 20,50 & 0,3530 & 0,5864 & 0,7797 & 20,50 & $-0,3949$ & $-0,3936$ & $-0,4018$ \\
\hline 25,00 & 0,6843 & 0,9155 & 1,1932 & 30,00 & $-0,2738$ & $-0,2948$ & $-0,3454$ \\
\hline 30,00 & 1,0164 & 0,9952 & 1,8728 & 41,50 & 0,8426 & 0,5460 & 0,1632 \\
\hline 41,50 & 2,3795 & 3,0707 & 3,9123 & 47,50 & 1,5689 & 1,6319 & 1,0111 \\
\hline 47,50 & 3,6863 & 4,3924 & 5,3774 & 53,00 & 1,2558 & 1,8547 & 1,4824 \\
\hline 53,00 & 3,5241 & 4,2197 & 5,1033 & 67,00 & 1,4443 & 2,1331 & 2,1397 \\
\hline 67,00 & 5,8430 & 6,7880 & 7,1572 & 95,00 & 1,6027 & 2,3096 & 2,2781 \\
\hline 95,00 & 9,4731 & 9,2639 & 10,1862 & 114,00 & 1,8606 & 2,6308 & 2,6264 \\
\hline 114,00 & 10,7935 & 10,3536 & 10,9213 & 139,00 & 2,2773 & 3,1810 & 3,1146 \\
\hline 139,00 & 12,7190 & 12,4594 & 13,0246 & 161,50 & 2,1893 & 3,0770 & 3,0451 \\
\hline 161,50 & 12,2308 & 11,5234 & 12,4659 & 186,50 & 2,0137 & 2,8002 & 2,7894 \\
\hline 186,50 & 11,1951 & 10,7094 & 11,4533 & 210,00 & 1,8862 & 2,6587 & 2,5704 \\
\hline 210,00 & 9,8415 & 10,2048 & 10,6758 & 329,00 & 2,9732 & 3,6032 & 3,8597 \\
\hline 329,00 & 8,1133 & 9,8907 & 10,0889 & 450,50 & 2,9196 & 3,6247 & 3,6389 \\
\hline 450,50 & 10,1094 & 9,2316 & 9,2167 & 503,50 & 2,8512 & 3,7400 & 3,5786 \\
\hline 503,50 & 10,8399 & 10,6927 & 11,0575 & 642,50 & 3,0591 & 3,9763 & 4,2990 \\
\hline 642,50 & 7,5459 & 6,9174 & 8,0119 & 715,00 & 3,1809 & 3,8716 & 3,9617 \\
\hline
\end{tabular}


APÊNDICE J - Consumo de sulfato nos reatores contendo acetato de sódio (triplicata).

\begin{tabular}{|c|c|c|c|c|c|c|c|}
\hline \multirow{2}{*}{$\begin{array}{c}\text { Tempo } \\
\text { acumulado (h) }\end{array}$} & \multicolumn{3}{|c|}{ Consumo de sulfato (mg/L) } & \multicolumn{2}{c|}{ Tempo } \\
acumulado (h) & \multicolumn{3}{|c|}{ Consumo de sulfato (mg/L) } \\
\cline { 2 - 4 } & Reatores controle & & \multicolumn{3}{c|}{ Reatores com oxigênio } \\
\cline { 2 - 3 } & Reator 1 & Reator 2 & Reator 3 & & Reator 1 & Reator 2 & Reator 3 \\
\hline 0,00 & 960 & 940 & 720 & 0,00 & 1000 & 920 & 840 \\
72,00 & 900 & 660 & 800 & 120,00 & 900 & 900 & 760 \\
168,00 & 800 & 640 & 860 & 288,00 & 580 & 520 & 640 \\
288,00 & 600 & 700 & 680 & 456,00 & 520 & 500 & 560 \\
456,00 & 660 & 560 & 580 & 624,00 & 300 & 320 & 280 \\
624,00 & 620 & 480 & 500 & 792,00 & 200 & 200 & 180 \\
792,00 & 540 & 460 & 440 & 984,00 & 20 & 40 & 80 \\
984,00 & 440 & 480 & 380 & & & & \\
\hline
\end{tabular}

APÊNDICE K - Consumo de sulfato nos reatores contendo etanol (triplicata).

\begin{tabular}{|c|c|c|c|c|c|c|c|}
\hline \multirow{3}{*}{$\begin{array}{c}\text { Tempo } \\
\text { acumulado (h) }\end{array}$} & \multirow{2}{*}{\multicolumn{3}{|c|}{$\begin{array}{c}\text { Consumo de sulfato }(\mathrm{mg} / \mathrm{L}) \\
\text { Reatores controle }\end{array}$}} & \multirow{3}{*}{$\begin{array}{c}\text { Tempo } \\
\text { acumulado (h) }\end{array}$} & \multirow{2}{*}{\multicolumn{3}{|c|}{$\begin{array}{c}\text { Consumo de sulfato }(\mathrm{mg} / \mathrm{L}) \\
\text { Reatores com oxigênio }\end{array}$}} \\
\hline & & & & & & & \\
\hline & Reator 1 & Reator 2 & Reator 3 & & Reator 1 & Reator 2 & Reator 3 \\
\hline 0,00 & 900 & 900 & 920 & 0,00 & 980 & 940 & 980 \\
\hline 72,00 & 780 & 720 & 680 & 72,00 & 740 & 660 & 680 \\
\hline 192,00 & 700 & 640 & 600 & 192,00 & 620 & 600 & 600 \\
\hline 360,00 & 460 & 480 & 500 & 360,00 & 460 & 420 & 380 \\
\hline 504,00 & 380 & 460 & 500 & 504,00 & 380 & 340 & 340 \\
\hline 672,00 & 340 & 380 & 380 & 672,00 & 280 & 220 & 180 \\
\hline
\end{tabular}


APÊNDICE L - Consumo de sulfato nos reatores contendo lactato de sódio (triplicata).

\begin{tabular}{|c|c|c|c|c|c|c|c|}
\hline \multirow{3}{*}{$\begin{array}{c}\text { Tempo } \\
\text { acumulado (h) }\end{array}$} & \multirow{2}{*}{\multicolumn{3}{|c|}{$\begin{array}{c}\text { Consumo de sulfato }(\mathrm{mg} / \mathrm{L}) \\
\text { Reatores controle }\end{array}$}} & \multirow{3}{*}{$\begin{array}{c}\text { Tempo } \\
\text { acumulado (h) }\end{array}$} & \multirow{2}{*}{\multicolumn{3}{|c|}{$\begin{array}{c}\text { Consumo de sulfato }(\mathrm{mg} / \mathrm{L}) \\
\text { Reatores com oxigênio }\end{array}$}} \\
\hline & & & & & & & \\
\hline & Reator 1 & Reator 2 & Reator 3 & & Reator 1 & Reator 2 & Reator 3 \\
\hline 0,00 & 760 & 980 & 860 & 0,00 & 880 & 840 & 740 \\
\hline 120,00 & 340 & 360 & 340 & 120,00 & 740 & 760 & 1020 \\
\hline 168,00 & 280 & & & 216,00 & 680 & 640 & \\
\hline 216,00 & 280 & 300 & 300 & 336,00 & 660 & 680 & 760 \\
\hline 336,00 & 340 & 360 & 340 & 504,00 & 380 & 660 & 540 \\
\hline 504,00 & 300 & 260 & 240 & 648,00 & 560 & 560 & 380 \\
\hline 648,00 & 180 & 220 & 220 & & & & \\
\hline
\end{tabular}

APÊNDICE M - Consumo ácido acéticos nos reatores em triplicara.

\begin{tabular}{|c|c|c|c|c|c|c|c|}
\hline \multirow{2}{*}{$\begin{array}{c}\text { Tempo } \\
\text { acumulado (h) }\end{array}$} & \multicolumn{3}{|c|}{$\begin{array}{c}\text { Consumo de ácido acético }(\mathrm{mg} / \mathrm{L}) \\
\text { Reatores controle }\end{array}$} & \multirow{2}{*}{$\begin{array}{c}\text { Tempo } \\
\text { acumulado (h) }\end{array}$} & \multicolumn{3}{|c|}{$\begin{array}{c}\text { Consumo de ácido acético }(\mathrm{mg} / \mathrm{L}) \\
\text { Reatores com oxigênio }\end{array}$} \\
\hline & Reator 1 & Reator 2 & Reator 3 & & Reator 1 & Reator 2 & Reator 3 \\
\hline 0,00 & 874,5 & 691,98 & 706,48 & 0,00 & & 643,5 & 763,78 \\
\hline 13,00 & 641,68 & 617,66 & 575,18 & 24,00 & 645,78 & 494,76 & 580,64 \\
\hline 24,00 & 493,58 & 525,04 & 417,3 & 48,00 & 497,94 & 499,7 & 584,26 \\
\hline 48,00 & 355,63 & 325,83 & 270,87 & 72,00 & 309,17 & 328,02 & 326,36 \\
\hline 72,00 & 110,02 & 120,64 & 3,1 & 120,00 & 8,34 & 4,34 & 3,94 \\
\hline 120,00 & 0 & 2,84 & 0 & & & & \\
\hline
\end{tabular}


APÊNDICE N - Consumo do etanol nos reatores em triplicata.

\begin{tabular}{|c|c|c|c|c|c|c|c|}
\hline \multirow{3}{*}{$\begin{array}{c}\text { Tempo } \\
\text { acumulado (h) }\end{array}$} & \multirow{2}{*}{\multicolumn{3}{|c|}{$\begin{array}{c}\text { Consumo de etanol }(\mathrm{mg} / \mathrm{L}) \\
\text { Reatores controle }\end{array}$}} & \multirow{3}{*}{$\begin{array}{c}\text { Tempo } \\
\text { acumulado (h) }\end{array}$} & \multirow{2}{*}{\multicolumn{3}{|c|}{$\begin{array}{c}\text { Consumo de etanol }(\mathrm{mg} / \mathrm{L}) \\
\text { Reatores com oxigênio }\end{array}$}} \\
\hline & & & & & & & \\
\hline & Reator 1 & Reator 2 & Reator 3 & & Reator 1 & Reator 2 & Reator 3 \\
\hline 0,00 & 348,76 & 287,3 & 454,9 & 0,00 & 245,76 & 230,48 & 216,78 \\
\hline 13,00 & 290,02 & 229,06 & 349,9 & 13,00 & 206,15 & 173,71 & 213,47 \\
\hline 21,00 & 247,32 & 253,9 & 213,65 & 21,00 & 196,7 & 149,06 & 197,25 \\
\hline 30,00 & 126,37 & 179,7 & & 30,00 & 150,64 & 78,67 & \\
\hline 48,00 & 19,96 & 24,7 & 20,38 & 48,00 & 81,5 & 88,87 & 23,03 \\
\hline 72,00 & 20 & 19,6 & 20,08 & 72,00 & 22,94 & 23,05 & \\
\hline
\end{tabular}

APÊNDICE O - Consumo de ácido lático nos reatores em triplicata

\begin{tabular}{|c|c|c|c|c|c|c|c|}
\hline \multirow{3}{*}{$\begin{array}{c}\text { Tempo } \\
\text { acumulado (h) }\end{array}$} & \multirow{2}{*}{\multicolumn{3}{|c|}{$\begin{array}{c}\text { Consumo de ácido lático }(\mathrm{mg} / \mathrm{L}) \\
\text { Reatores controle }\end{array}$}} & \multirow{3}{*}{$\begin{array}{c}\text { Tempo } \\
\text { acumulado (h) }\end{array}$} & \multirow{2}{*}{\multicolumn{3}{|c|}{$\begin{array}{c}\text { Consumo de ácido lático }(\mathrm{mg} / \mathrm{L}) \\
\text { Reatores com oxigênio }\end{array}$}} \\
\hline & & & & & & & \\
\hline & Reator 1 & Reator 2 & Reator 3 & & Reator 1 & Reator 2 & Reator 3 \\
\hline 0,00 & 934,5 & 1000,5 & 1020,1 & 0,00 & 941,6 & 903,4 & 864,4 \\
\hline 11,00 & 945,4 & 667,1 & 717,6 & 11,00 & 769,1 & 761,3 & 710,3 \\
\hline 21,00 & 696,3 & 543,5 & 643,8 & 21,00 & 112,8 & 235,70 & 222,8 \\
\hline 32,00 & 638,4 & 753,3 & 632 & 32,00 & 44,6 & 96,2 & 153,1 \\
\hline 48,00 & 530,4 & 506,7 & & 48,00 & 0 & 21,9 & 4,3 \\
\hline 55,00 & 7,1 & 0 & 15,3 & 55,00 & 0 & 0 & 0 \\
\hline 72,00 & 0 & 0 & 0 & & & & \\
\hline
\end{tabular}


ANEXO A - Curva de calibração do ácido acético.

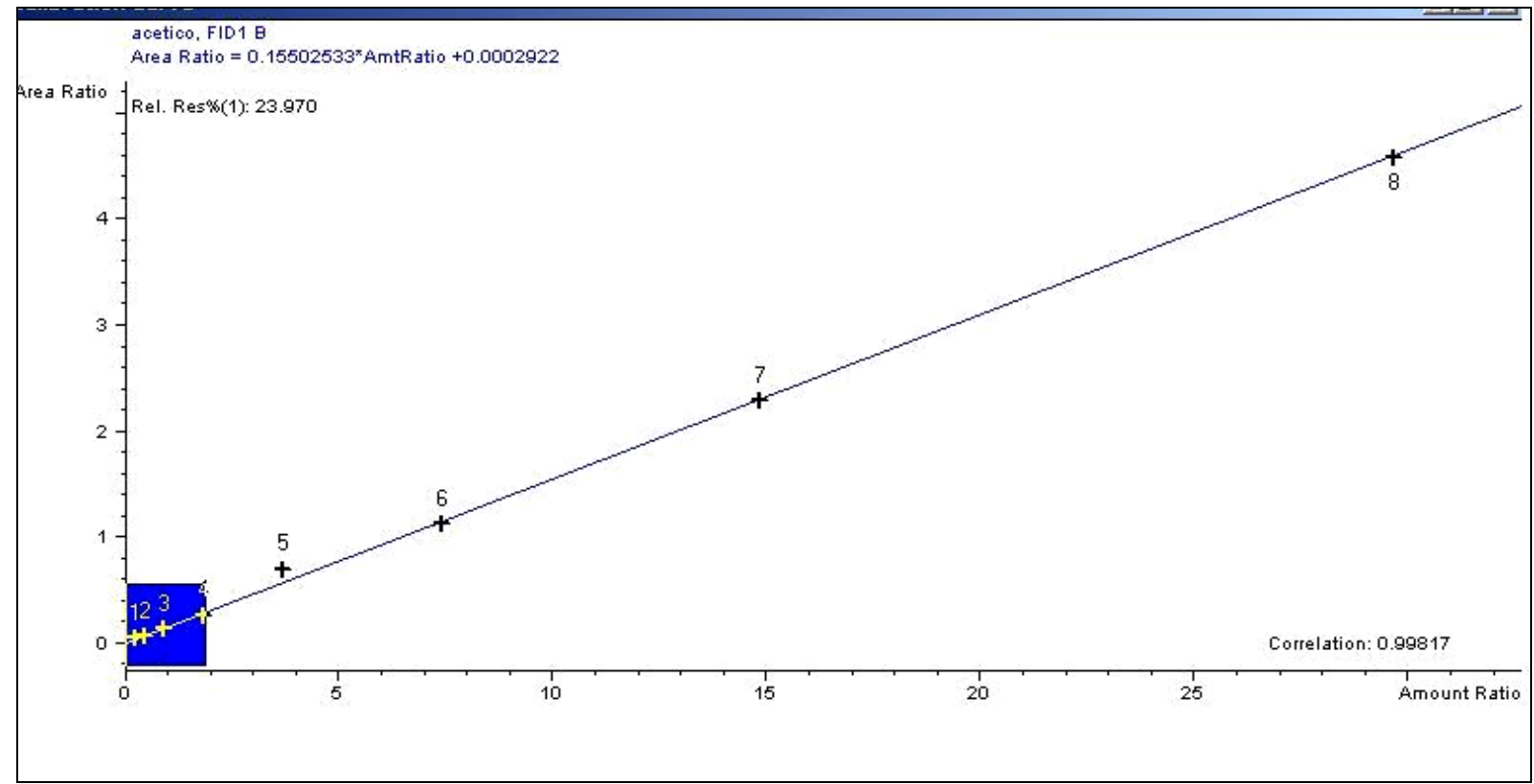

ANEXO B - Curva de calibração do etanol.

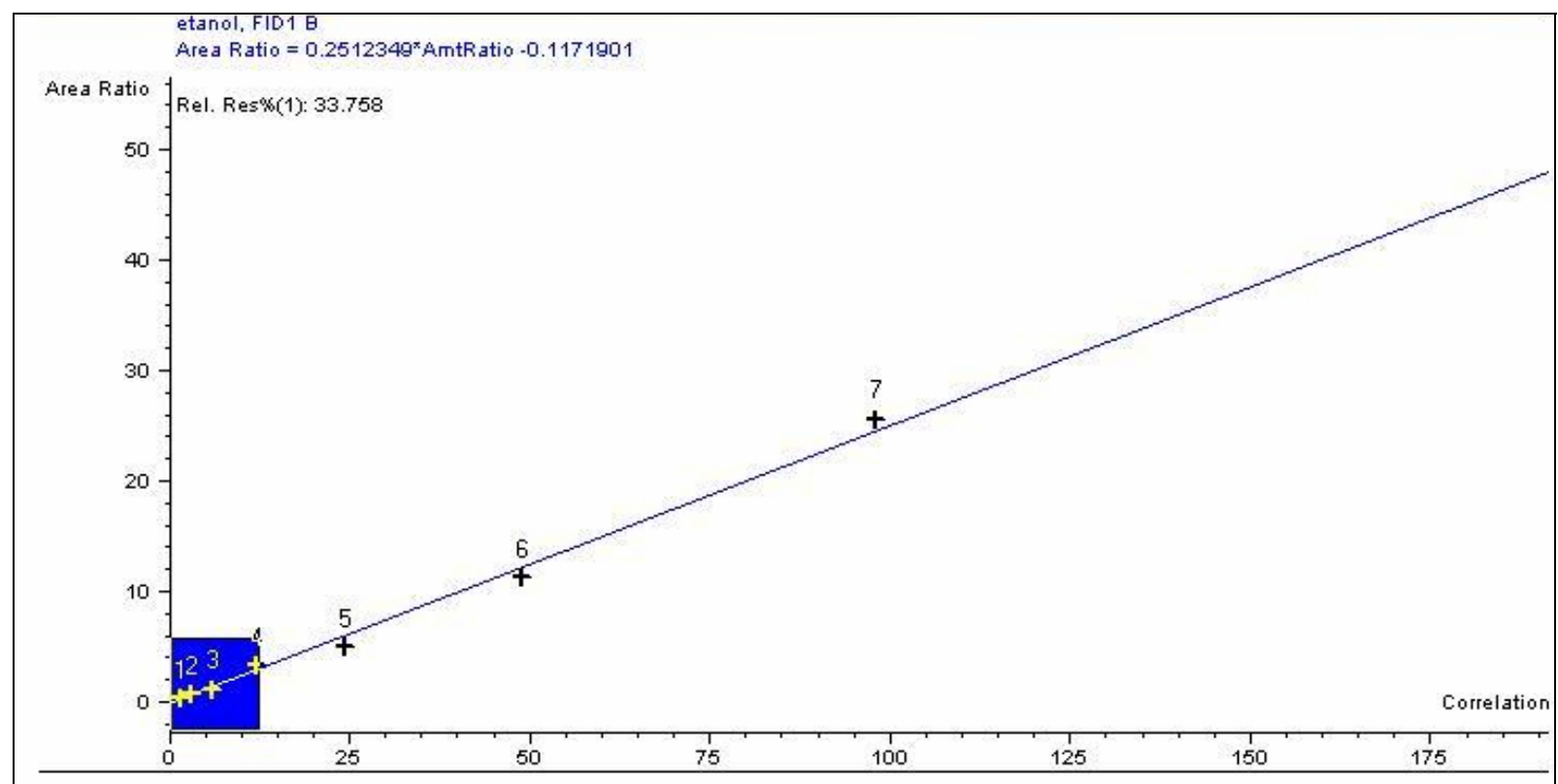


ANEXO C - Curva de calibração do ácido lático.

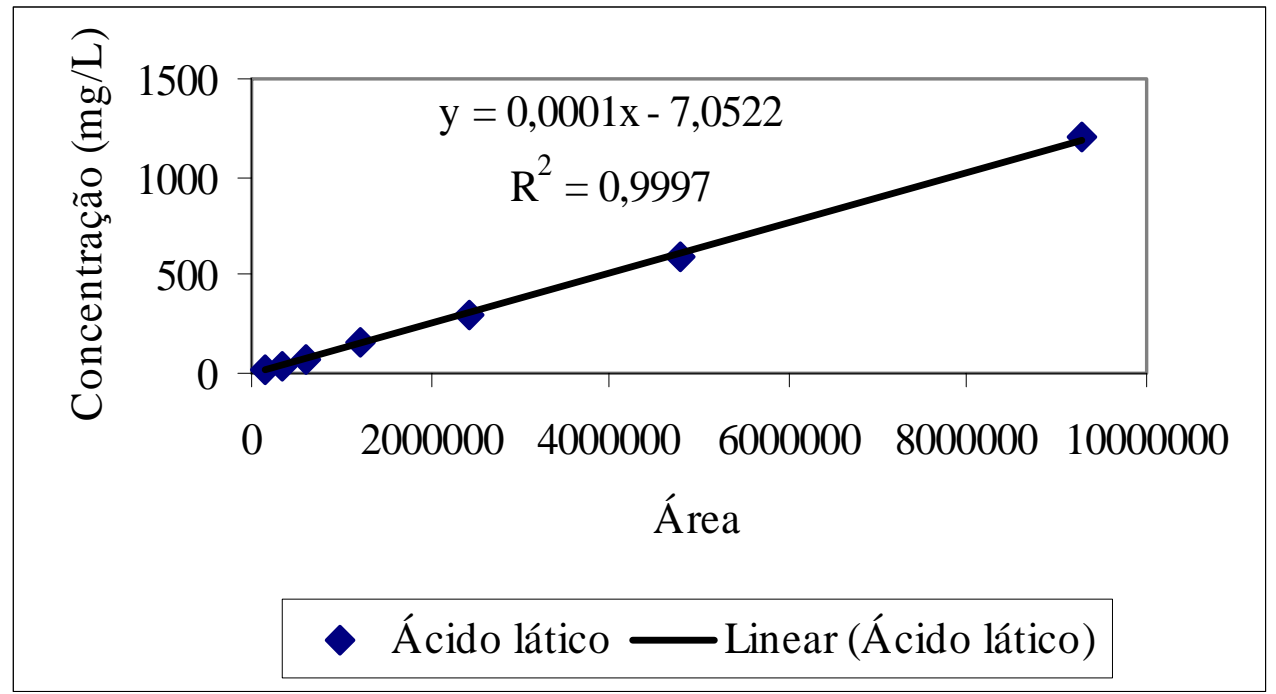

